\title{
Identifikation geeigneter Nachweismöglichkeiten von hormonaktiven und reproduktionstoxischen Wirkungen in aquatischen Ökosystemen
}

\author{
Robert Kase $\cdot$ Petra Kunz $\cdot$ Almut Gerhardt
}

Erhalten: 9. April 2009/Akzeptiert: 9. Juni 2009/Online veröffentlicht: 16. Juli 2009

(C) Die Autoren 2009. Dieser Artikel wurde mit Open Access auf Springerlink.com veröffentlicht.

Zusammenfassung Hintergrund und Ziel Aus den Ergebnissen umfangreicher Forschungsprogramme, wie z. B. dem Schweizer Forschungsprojekt NFP50 „Hormonaktive Stoffe" und deren Konsensplattformen zeigt sich ein zunehmender Handlungsbedarf hormonaktive Wirkungen in aquatischen Systemen nachweisen, bewerten und reduzieren zu können. Die EU-Strategie für endokrine Disruptoren beinhaltet als mittelfristige Maßnahmen die Beteiligung der „Organisation for Economic Co-operation and Development" (OECD) durch die ,Endocrine Disruptor Testing and Assessment Task Force" (EDTA) und weitere Forschungsaktivitäten. Die Testverfahrensentwicklungen der OECD können erhebliche Beiträge zum Verständnis des Ausmaßes der endokrinen Disruption leisten, sofern diese auch auf Umweltproben angewendet und für Risikominderungsstrategien (z. B. Abwasserbehandlungen) eingesetzt werden. Ziel dieses Reviews ist es, eine Zusammenfassung und Bewertung von verfügbaren und in der Validierung befindlichen biologischen Testsystemen zu erstellen, mit denen Effekte hormonaktiver und reproduktionstoxischer Substanzen in Gewässern nachgewiesen werden können. Auf dieser Grundlage erfolgt eine Empfehlung einer ökotoxikologischen Testpalette, die es erlaubt, die unterschiedlichen Mechanismen der hormonaktiven Wirkungen und reproduktionsrelevanten Wirkungen zuverlässig in Umweltproben zu erfassen. Der Schwerpunkt dieser Arbeit liegt auf den Testverfahren für geschlechtshormonaktive Substanzen.

Material und Methoden Ausgehend von einer Literaturrecherche und aktuellen internationalen Validierungsaktivitäten für Nachweismöglichkeiten hormonaktiver und repro-

R. Kase $(\bowtie) \cdot$ P. Kunz $\cdot$ A. Gerhardt

Oekotoxzentrum, Eawag/EPFL,

Überlandstrasse 133, Postfach 611, 8600 Dübendorf, Schweiz

E-Mail: kase.robert@googlemail.com duktionstoxischer Substanzen und Wirkungen wurden 15 biologische Testverfahren (5 In-vivo- und 10 In-vitro-Testverfahren) ausgewählt. Es wurden 8 Verfahren der OECDEDTA erfasst und 3 von 5 In-vitro-Verfahren aus dem ,Global Water Research Coalition“ (GWRC) Report: „Tools to detect estrogenic activity in environmental waters“ (Leusch 2008) ausgewählt. Für diese Testverfahren erfolgte eine Abfrage umfassender Kriterienprofile bei versierten Anwendern und Entwicklern, die vergleichend dargestellt und ausgewertet wurden.

Ergebnisse Wichtige Kriterien bei der Auswahl der Testverfahren waren Normung/Validierung oder Verbreitung und Standardisierbarkeit der Tests sowie eine nachgewiesene Sensitivität in der Bewertung von Umweltproben. Bei den In-vitro-Tests erfüllen dies unserer Meinung nach bestimmte YES/YAS-Systeme (Yeast Estrogen/Androgen Screen Assay) und die ER/AR-Calux-Verfahren (Estrogen/ Androgen Receptor). Sollte deren Anwendung durch starke zytotoxische Effekte in Umweltproben behindert werden, kann z.B. ein molekularer Rezeptorbindungsassay, wie der ELRA, Rezeptorbindungspotenziale nachweisen. Weitere molekulare Rezeptorbindungsassays sind derzeitig in der Validierung der OECD. Ebenfalls von der OECD für Einzelsubstanzen validiert, kann der H295R Steroidgenesis Assay Modulationen der Steroidgenese, und eventuell sogar aromatasemodulierende Effekte nachweisen. Seine Anwendbarkeit auf Umweltproben wird derzeitig getestet. Für die In-vivo-Stufe der modularen Testplattform wurden verschiedene Fischtests (z. B. der Fish Screening Assay und der Fischeitest) bewertet. Um Einflüsse auf das thyroidale Hormonsystem nachzuweisen ist der Amphibian Metamorphosis Assay (in der Abfrage unter XEMA, Xenopus Metamorphosis Assay) am weitesten validiert und wird bald als offizielle OECD-Richtlinie erscheinen. Da es sich auch hier um einen Vertebratentest handelt und internationale Be- 
strebungen bestehen Vertebratentests zu vermeiden, erfolgte nur eine optionale Empfehlung. Reproduktionstoxische Wirkungen können z. B. sehr sensitiv im Schneckenreproduktionstest mit Potamopyrgus antipodarum nachgewiesen werden. Dieser reagiert auch auf viele Substanzen, die in Vertebraten eine endokrine Disruption verursachen. Eine Validierung erfolgt derzeitig durch die OECD. Eine Eignung der in der modularen Testpalette vorgeschlagenen Verfahren für Umweltprobenbewertungen wurde angegeben und kann durch mehrere Literaturquellen belegt werden.

Diskussion Es wurde eine anwendungsorientierte modulare Testpalette mit verschiedenen Testverfahren vorgeschlagen, die möglichst effektiv und vielseitig die Mechanismen der endokrinen Disruption und die Reproduktionstoxizität nachzuweisen vermögen und sich dabei in ihren Stärken und unterschiedlichen Arbeitsbereichen ergänzen. Es können fortpflanzungsrelevante Wirkungen an Invertebraten, Amphibien und Fischen und die wirkmechanistischen Ansätze der östrogenen und androgenen Rezeptorbindung, der Steroidgenese, eventuell sogar der Aromatasemodulation erfasst werden. Neuere Forschungsergebnisse, wie z. B. der Forschungsbericht zur Gewässerrelevanz endokriner Stoffe und Arzneimittel (Moltmann et al. 2007), konnten anhand aquatisch relevanter Schadstoffe mit In-vivo-Tests nachweisen, dass endokrine Endpunkte (bei 31 von 71 untersuchten Stoffen) empfindlicher sein können als allgemeine ökotoxikologische Endpunkte (z. B. Mortalität, Wachstum usw.). Daher wird empfohlen endokrine Effekte nicht isoliert zu betrachten, sondern parallel mit allgemeintoxischen und fortpflanzungsrelevanten Wirkungen in ökotoxikologischen Biotestpaletten integrativ zu erfassen.

Schlussfolgerungen Durch die Kombination einer Literaturrecherche und der gezielten Abfrage von Informationen zu den Testverfahren konnte eine umfassende, aber auch detaillierte Übersicht zum derzeitigen Stand der Wissenschaft und Technik gegeben werden. Dabei wurden ökotoxikologische und regulative Aspekte der Testverfahren gleichermaßen berücksichtigt und deren Praktikabilität für ein Umweltmonitoring in aquatischen Systemen bewertet. Bei der Vielfältigkeit der endokrinen Wirkmechanismen bedarf es einer modularen Kombination von In-vivo- und In-vitro-Verfahren in einer Testpalette, um auch die fließenden Übergänge von hormonaktiven Wirkungen bis hin zu einer manifestierten endokrinen Disruption erfassen und differenzieren zu können.

Empfehlungen und Perspektiven Die vorgestellte Testpalette erlaubt einen umfassenden Schutz vor hormonaktiven und reproduktionsrelevanten Effekten, wobei eine Anpassung an die Interessen und Zielsetzungen der Anwender erfolgen kann. Es werden sowohl die regulativen und ökotoxikologischen Anforderungen an Testsysteme als auch die aktuellen Entwicklungen in der EU und der OECD mit berücksichtigt. Eine weiterführende Normung dieser Verfahren für den regulativen Einsatz in der Umweltüberwachung und für Risikominderungsstrategien ist zu empfehlen. Das modulare System erlaubt es, einen anwendungsorientierten Austausch der Testmodule nach dem sich kontinuierlich entwickelnden Stand der Technik ohne Neuentwicklungen auszuschließen.

Schlüsselwörter Aquatische Ökotoxikologie $\cdot$ Biotestpaletten · Endokrine Disruption · Fortpflanzungsgefährdende Wirkungen · Gewässerschutz · Hormonaktive Wirkungen $\cdot$ Monitoring $\cdot$ Normungen $\cdot$ Reproduktionstoxische Wirkungen $\cdot$ Teststrategien

\section{Identification of reliable test procedures to detect endocrine disruptive and reproduction toxic effects in aquatic ecosystems}

Abstract Background and objectives There is an urgent need to detect, assess, and reduce effects of hormonally active compounds and endocrine disrupters in aquatic systems, as reflected in national research programs like the Swiss NRP 50 "Endocrine Disruptors" and its consensus platforms. As a medium-term measure, the EU strategy on endocrine disruptors (SEC(2007)1635) uses the Endocrine Disruptor Testing and Assessment (EDTA) Task Force of the Organisation for Economic Co-operation and Development (OECD) along with other research activities. In particular the test methods of the OECD that are currently in validation or already validated may contribute to a better understanding of the extent of endocrine disruption, in particular if they are applied on environmental samples and in the context of risk-assessment strategies, for instance in waste water treatment. This article aims to give an overview and an evaluation on available and validated biological test systems for the detection of endocrine disruptive and reproductive effects in aquatic systems. Based on this a recommendation for a modular ecotoxicological test platform is given. The study focuses on test methods for sex hormone active substances.

Material and methods On the basis of an extensive literature search and ongoing international validation efforts by the OECD for methods to detect endocrine disruptive effects, 15 biological test methods (5 in vivo and 10 in vitro) were selected. Comprising, for example, of eight OECD methods and three out of five in-vitro methods mentioned in the Global Water Research Coalition (GWRC) report "Tools to detect estrogenic activity in environmental waters" (Leusch 2008). Experienced users and developers were then asked to rate the test according to given relevant criteria. The resulting criteria profiles were compiled, compared, and evaluated.

Results The methods were selected on the basis of validation status, distribution, their suitability for standardisation, and their proven sensitivity for environmental samples. We 
assumed that specific YES/YAS-procedures and the ER/AR Calux systems achieve the mentioned criteria. In the case that strong cytotoxicity of environmental samples affects the applicability of cellular reporter gene assays, alternatively a molecular receptor binding assay (e.g. ELRA) could be used. Additional molecular receptor binding assays are currently in validation by the OECD. Modulating effects on steroidgenesis and probably even on aromatase activity can be detected by the OECD validated H295R Steroidgenesis Assay. Its applicability for environmental samples is currently tested. As in-vivo methods different fish assays (e.g. Fish Screening Assay and the Zebrafish Embryo Test) were evaluated. For the detection of effects on the thyroid-associated hormone system the Amphibian Metamorphosis Assay (XEMA, for Xenopus Metamorphosis Assay) will soon be available as an OECD-Guideline. Because of trends in the international community to avoid tests with vertebrates in the future, only an optional recommendation was given for such tests. Reproduction toxicity, on the other hand, can be sensitively tested by the tests using the gastropod Potamopyrgus antipodarum, which, as invertebrate tests, do not require a permit to perform animal testing procedures. This test is also sensitive for many substances which are able to induce an endocrine disruption in vertebrates. Its validation is currently performed by the OECD. The applicability of the herein proposed test methods of the modular test platform for environmental-sample assessments were previously confirmed by several published scientific studies.

Discussion We propose several test methods to be included in an application-oriented modular test platform. These tests should be suitable to efficiently indicate different mechanisms of endocrine disruption and reproduction toxicity, and may be employed in different situations according to their respective advantages. The modular test platform is able to detect impacts on the reproduction relevant effects in invertebrates, amphibians, and fishes. Furthermore the different mode of actions of estrogenic and androgenic receptor binding, steroid genesis and perhaps even the modulation of aromatase are detectable. A research report on the relevance of endocrine substances and pharmaceuticals in aquatic environments (Moltmann et al. 2007) showed that endocrine end-points of in-vivo tests (31 of 71 tested substances) tend to be more sensitive than general ecotoxicological endpoints, such as mortality and growth. Consequently, endocrine and general-toxic effects should be detected in an integrative manner by ecotoxicological test platforms.

Conclusions By combining literature research with a targeted query for information about the chosen test procedures it was possible to obtain a detailed overview about the current state-of-the-art of science and technology in the detection of hormone-active effects and reproduction toxicity. Ecotoxicological and regulative aspects were considered equally, and the applicability of the test procedures was evaluated. Because of the diversity of endocrine disrupting mechanisms, a modular combination of in-vivo and in-vitro methods in a joint test platform is needed to recognise and differentiate the transitions from hormone-active effects to endocrine disruption.

Recommendations and perspectives Our study leads to a proposal of a modular ecotoxicological test platform, which offers an integrative detection of hormone-active and reproduction-relevant effects in the aquatic environment. The modular system presented here allows the switching between test modules according to the continuously developing state-of-the-art of science and technology as well as the incorporation of novel developments. Further standardisation of such methods for regulative applications is recommended.

Keywords Aquatic ecotoxicology - Biotest battery · Endocrine disruption · Hormone-active effects ·

Monitoring $\cdot$ Reproduction relevant effects $\cdot$ Reproduction toxic effects $\cdot$ Standardisation $\cdot$ Test strategies $\cdot$

Water pollution control

\section{Einleitung}

\subsection{Hormonaktive Wirkungen und endokrine Disruptoren}

Hormone sind Botenstoffe, die eine Vielzahl von Prozessen zwischen Geweben und Zellen regulieren. So stehen z.B. weibliche und männliche Hormone (Östrogene und Androgene) im Organismus in einem empfindlichen Gleichgewicht, welches durch Stoffe mit hormonaktiven Wirkungen gestört werden kann. Das Ausmaß dieser Störungen wurde in den letzten Jahrzehnten immer deutlicher und steht weiterhin im Blickpunkt wissenschaftlichen und öffentlichen Interesses. Hormone, deren Wirkungsort örtlich getrennt vom Syntheseort liegt, werden endokrine Hormone genannt. Nach der Weybridge-Definition (EU-Konferenz 1996) ist ein endokriner Disruptor eine exogene Substanz oder eine Mischung von Stoffen, die die Funktion des endokrinen Systems ändert und infolgedessen gesundheitsschädigende Wirkung in einem gesundem Organismus, seiner Nachkommenschaft oder einer (Sub-)Population hervorruft (EC 1997). Endokrine Disruptoren (Endocrine Disrupting Compounds, EDC) können natürliche endogene Hormone in ihrer Wirkungsweise nachahmen bzw. hindern oder die Synthese bzw. den Metabolismus dieser Hormone oder deren Hormonrezeptoren stören (Sonnenschein und Soto 1998). Endokrine Disruptoren besitzen demnach eine hormonaktive Wirkung. Eine hormonaktive Wirkung muss jedoch nicht zu einer vollständigen Disruption der hormonellen Gleichgewichtslage führen, da Ausmaß und Wirkrichtung variieren können. Dennoch können hormonaktive Substanzen eine hohe öko- 
toxikologische Bedeutung besitzen, wenn sie eine Beeinträchtigung der Fortpflanzung von Tieren bewirken und sich auf das Überleben von Populationen auswirken. Der Begriff „hormonaktive Wirkung“ ist genereller und soll eine allgemeine Wirkung auf das hormonelle System beschreiben.

Durch Studien belegte Wirkungen von exogenen hormonaktiven Substanzen und endokrinen Disruptoren in Invertebraten (INV) und Vertebraten (VER), verändert nach Bätscher et al. (1999), Damstra (2003), FNSNF (2008a), Matthiessen (2000), und UBA-Texte (1995), sind:

- Veränderung des Reproduktionsverhaltens und der Reproduktionsfähigkeit (INV, VER)

- Beeinflussung des neurohormonellen Systems und der Immunfunktionen (INV, VER)

- Störung der Gleichgewichtslage von Geschlechtshormonen (INV, VER)

- diverse Veränderungen in Gehirn und Geschlechtsorganen (INV, VER)

- Verlust von Geschlechtszellen, Sterilität oder gar Geschlechtsumwandlung bzw. Intersexstadien (INV, VER),

- Störung der Entwicklung und Beschaffenheit von Spermien und Eizellen (INV, VER)

- Beeinflussung der sekundären Geschlechtsdeterminierung (VER) und

- Fehlbildungen in der Embryonalentwicklung (VER)

- Mehrere Studien weisen auf ein erhöhtes Krebsrisiko hin, z. B. für Brust- und Hodenkrebs (VER)

Eine Reproduktionstoxizität kann sowohl durch hormonaktive Substanzen als auch durch unspezifisch wirkende, toxische Substanzen verursacht werden. Aus dieser Vielfalt der möglichen Wirkungen ergeben sich für Ökotoxikologen große Herausforderungen geeignete Verfahren zu entwickeln, die einen Großteil dieser Wirkungen abbilden und für eine Risikoabschätzung herangezogen werden können. So beschäftigten sich mehr als $25 \%$ (67 von 264$)$ der Beiträge auf der europäischen SETAC 2008, einer der wichtigsten internationalen Tagungen für Ökotoxikologen, mit hormonaktiven Wirkungen und mit der Identifikation endokriner Disruptoren. Im Gegensatz zur Vielfalt der möglichen Wirkungen repräsentiert die hormonelle Regulation der biologischen Funktionen ein gemeinsames Charakteristikum für sämtliche tierische Organismen und liegt in den basalen Wirkmechanismen weitgehend phylogenetisch gut konserviert vor (Oehlmann und Schulte-Oehlmann 2003). Trotz der Ähnlichkeiten vieler Systembestandteile besteht auch innerhalb der Invertebraten-Taxa eine endokrinologische Variabilität und es ist nach bisherigem Wissensstand nicht möglich Vorhersagen für Wirbeltiere einschließlich des Menschen abzuleiten. Eine Fokussierung der Untersuchungen auf artübergreifende Endpunkte mit breitem Indikationswert ist sinnvoll.

Eine Einteilung der geschlechthormonaktiven Substanzen kann nach ihrer Wirkrichtung erfolgen. Entfaltet ein
Fremdstoff die gleichen Wirkungen wie beispielsweise körpereigene Östrogene oder Androgene, so wird er als östrogen bzw. androgen bezeichnet. Verhindert ein Stoff jedoch die Wirkung von körpereigenen Geschlechtshormonen, wird seine Wirkung als antiöstrogen bzw. antiandrogen bezeichnet (Fent 2000). Generell lassen sich vermännlichende und verweiblichende Wirkungen unterscheiden. Die Wirkungen können u.a. hormonrezeptorvermittelt, durch Einfluss auf Synthese und Metabolismus von Hormonen, z.B. durch Modulation der Aromataseaktivitität oder der Steroidgenese auftreten. Zusätzlich zu den geschlechtshormonaktiven Wirkungen können endokrine Disruptoren ebenfalls eine Beeinflussung des thyroidalen Hormonsystems oder der glucocorticoidalen Stressantwort auslösen. Unter den hormonaktiven Substanzen sind östrogene Wirkstoffe weitaus besser untersucht als androgen oder thyroidal wirksame Substanzen. Dieses Verhältnis spiegelt sich auch in der Anzahl bekannter Östrogene zu den anderen endokrinen Disruptoren wieder. Im Rahmen der EU-Strategie für endokrine Disruptoren wurden 564 Verdachtsstoffe gelistet (BKH 2000) und durch weitere Verdachtsstoffe ergänzt. Für 71 Stoffe aus einer erweiterten Gesamtliste konnten endokrine Wirkungen auf aquatische Organismen in vivo festgestellt werden (Moltmann et al. 2007).

1995 fand das erste Fachgespräch des deutschen Umweltbundesamtes zu Umweltchemikalien mit endokriner Wirkung statt (UBA-Texte 1995). Im Rahmen dieses Gesprächs wurde festgestellt: „Die Problematik von Umweltchemikalien, welche auf das endokrine System einwirken, hat in den letzten Jahren große Bedeutung erlangt, weil unerwartete Effekte in aquatischen Ökosystemen beobachtet wurden.“ (Fent 1995) Parallel dazu sind auch Befunde der Toxikologie und Reproduktionsbiologie von Mensch und Säugern veröffentlicht worden, welche die Problematik schlagartig in den Brennpunkt einer breiteren Öffentlichkeit rückten. Das verstärkte Interesse an endokrinen Disruptoren besteht also schon seit mehr als 10-15 Jahren, seitdem wurde viel Forschung in diese Thematik investiert und hat teilweise auch Eingang in gesetzliche Grundlagen gefunden.

\subsection{Gesetzliche Grundlagen und regulatorische} Bestrebungen zur Erfassung von hormonaktiven und reproduktionstoxischen Wirkungen

Das Interesse endokrine Disruptoren zu identifizieren ist international. Die US-amerikanische Umweltbehörde (Environmental Protection Agency, US-EPA) erhielt 1996 das legislative Mandat ein Screening-Programm zum Nachweis endokriner Disruptoren (EDSP) zu entwickeln (Hartig et al. 2008). In diesem Programm sollten geeignete ScreeningMethoden für endokrine Wirkungen entwickelt, validiert und implementiert werden (Ankley et al. 1997). Viele der nationalen Entwicklungen des EDSP konnten in eine 
OECD-EDTA-Richtlinie zur Erfassung endokriner Disruptoren einfließen. Eine Variante dieser Richtlinie ist mittlerweile in Kraft getreten und erfordert eine Neubewertung der Chemikalien bezüglich endokriner Disruptoren in den USA durch die Industrie (US-EPA 2008, 2009). In Japan wurde 1998 ein Strategieprogramm über endokrine Disruptoren in der Umwelt mit dem Namen SPEED (Strategic Program on Environmental Endocrine Disruptors) initiiert, welches von der japanischen Umweltbehörde geleitet wird (Oikawa und Matsumoto 2003). Schon vor mehr als 10 Jahren wurde im Auftrag des deutschen Umweltbundesamtes der Kenntnisstand von über 200 als endokrin wirksam verdächtigen Umweltchemikalien anhand der Literatur zusammengetragen (Gülden et al. 1997). Neben der hormonellen Wirksamkeit wurde die Gewässerrelevanz dieser Stoffe anhand von Messdaten aus einer Umfrage bei den Bundesländern und aus den Datenbanken des Umweltbundesamtes, der Flussgebietsgemeinschaften sowie anhand von Erkenntnissen zu Produktion und Verhalten dieser Stoffe in der Umwelt bewertet. Aussagen zur Gewässerrelevanz der Stoffe erwiesen sich jedoch als nur bedingt möglich, da für die Mehrzahl der Stoffe keine Messdaten im Gewässer vorlagen und außerdem die relative Wirksamkeit der Stoffe nicht bekannt war.

Das Schweizer Bundesamt für Umwelt (BAFU) kam in Kooperation mit der Eidgenössischen Anstalt für Wasserversorgung, Abwasserreinigung und Gewässerschutz (Eawag) 1999 zu dem Schluss, dass sowohl im Bereich der Belastungssituation als auch im Bereich der Wirkungen ein erheblicher Forschungsbedarf besteht (Bätscher et al. 1999). Auf eine Initiative des Schweizer Bundesrates hin wurde von 2002 bis 2007 das nationale Forschungsprogramm 50 (NFP50) „Hormonaktive Stoffe: Bedeutung für Menschen Tiere und Oekosysteme" durchgeführt und umfasste 31 wissenschaftliche Projekte (FNSNF 2008a). In diesem Forschungsprogramm sollten Strategien zur Beurteilung der Risiken und Gefahren der Belastung von Menschen, Nutzund Wildtieren und der Umwelt durch hormonaktive Stoffe in Ökosystemen entwickelt werden. Auf der Basis der Forschungsresultate wurden gemeinsam mit Behörden und Industrie Empfehlungen in drei Konsensplattformen ausgearbeitet, die mithelfen sollen, negative Folgen hormonaktiver Chemikalien zu vermeiden. Besonders für eine Erfassung der Situation der hormonaktiven Stoffe im Abwasser- und Gewässerbereich ist das Abschlussdokument der Konsensplattform (FNSNF 2008b) bestens geeignet, da es ebenfalls den weiteren Forschungs- und Handlungsbedarf darstellt. Aufgrund der Länge des Artikels kann hier nur ein gekürzter Auszug für die Testverfahren gegeben werden:

„Durch Abwassereinleitungen dürfen sich im Fliessgewässer keine Effekte aufgrund der aus dem Abwasser zugeführten östrogenen Stoffe ergeben (Schutzziel). Die Gesamtbelastung von Gewässern mit hormonaktiven Stoffen könnte mit Biotests in Speziallabors bestimmt werden.
Diese sind für eine Gesamtbeurteilung einer Einzelstoffanalytik vorzuziehen. Es ist aber praktisch unmöglich, mit gängigen Testverfahren Qualitätskriterien festzulegen, die alle Organismen vor nachteiligen Effekten schützen. Die rasche Entwicklung von international anerkannten Verfahren zum Nachweis hormonaktiver Eigenschaften von Chemikalien und Gemischen muss gefördert werden. Das Gleiche gilt für Testverfahren zur Priorisierung von Mikroverunreinigungen und zur Überwachung der Gewässerqualität. Für die Praxis ist die Etablierung von wissenschaftlich fundierten Qualitätskriterien für die Gewässerqualität anzustreben: ein chronisches Qualitätskriterium für Dauerbelastungen und ein akutes Qualitätskriterium für kurzfristige Spitzenbelastungen. Es wird empfohlen, die Gewässerschutzverordnung mit diesen Qualitätskriterien zu ergänzen." (FNSNF 2008b)

In Europa werden in der laufenden Umsetzung der europäischen Wasserrahmenrichtlinie (2000/60/EG (WRRL) 2000; COM 2006) im Hinblick auf die Minderung gefährlicher Chemikalien in Oberflächengewässern zunehmend auch endokrine Wirkungen berücksichtigt. Die EUStrategie für endokrine Disruptoren (COM (99)706 1999; SEC(2007)1635 2007) sieht eine Reihe von kurz-, mittelund langfristigen Maßnahmen vor, zu denen auch die Erstellung einer Liste potenziell endokriner Stoffe und ihre Priorisierung zählen. Eine solche Liste wurde 2000 erstellt (BKH 2000) und von der EU-Kommission vorgestellt. Ausgehend von 564 Substanzen wurden in einem vierstufigen Verfahren 60 Substanzen mit hoher Priorität identifiziert. Diese Substanzen zeigten sich in mindestens einer In-vivo-Studie als endokrin wirksam und waren persistent oder traten in hohen Produktionsvolumina auf. Der Bericht räumte jedoch umfangreiche Lücken im Wissensstand zu den endokrinen Disruptoren ein und beinhaltete auch mehrfache Empfehlungen für eine weitere Bewertung dieser Chemikalien. So wurde u. a. empfohlen, dass Standardtests entwickelt werden müssen um endokrine Disruptoren identifizieren zu können und dass eine Risikobewertung nur möglich ist, wenn vereinbarte Testverfahren verfügbar sind. In einem Folgeprojekt wurde versucht ein Teil der Datenlücken für 435 Substanzen zu schließen (RPS BKH 2002). Die aktuelle Ergebnislage zu dieser Gesamtliste befindet sich in einem Arbeitsdokument der EU-Kommission (SEC(2007)1635 2007) und behandelt auch die Implementierung der europäischen Strategie für endokrine Disruptoren. Die Gewässerrelevanz der potenziellen endokrinen Disruptoren wurde in einem Forschungsprojekt des deutschen Umweltbundesamtes untersucht. Für 71 Stoffe aus einer erweiterten Gesamtliste konnten endokrine Wirkungen auf aquatische Organismen in vivo festgestellt werden (Moltmann et al. 2007). Jedoch lagen nur für 38 von 71 dieser Stoffe Messdaten zu Umweltkonzentrationen aus Oberflächengewässern vor, so dass auch nur teilweise Umweltqualitätsnormvorschläge abgeleitet werden konnten. Mit 
In-vivo-Tests konnte gezeigt werden, dass endokrine Endpunkte (bei 31 von 71 untersuchten Stoffen) empfindlicher sein können als allgemeine ökotoxikologische Endpunkte (z.B. Mortalität, Wachstum usw.). Eine Erfassung der endokrinen Wirkung durch Einbindung in Monitorprogramme wurde angeregt, indem beispielsweise die integrierte Kombination aus biologischen Wirkungstests und chemischen Analysen untersucht wird, um grundsätzlich Wirkungen in Gewässern festzustellen und sie bestimmten Stoffen zuordnen zu können (Moltmann et al. 2007).

Reproduktionstoxische Wirkungen fanden Einzug in die Pflanzenschutzmittelrichtlinie (91/414 EWG) und der europäischen Chemikalienbewertung nach REACH (Registration Evaluation Authorisation of Chemicals). Die Umsetzung der Pflanzenschutzmittelrichtlinie und REACH könnten sich mittel- und längerfristig mildernd auf die Belastungssituation aquatischer Systeme mit reproduktionstoxischen und endokrinen Substanzen auswirken. Beide beinhalten neben anderen toxikologischen Wirkungen auch Erfassungen von reproduktionstoxischen Endpunkten und setzen diese teilweise um. So unterliegen in REACH karzinogene, mutagene und reproduktionstoxische Substanzen (CMR-substances) einer gesonderten Zulassungspflicht. Dabei müssen chronische Wirkungen aber generell erst bei höheren Jahrestonnagen ( $>100 \mathrm{t} / \mathrm{a}$ ) untersucht werden und die Testung auf reproduktionstoxische Effekte im Zwei-Generationen-Test ist erst ab $1000 \mathrm{t}$ /a verpflichtend. Endpunkte für Substanzen mit hormonaktiver Wirkung sind zurzeit weder in REACH noch in der Pflanzenschutzmittelrichtlinie zwingend erforderlich und es stellt sich die Frage, inwieweit und wann diese regulatorischen Instrumente helfen werden die vorhandene Belastungssituation durch hormonaktive Substanzen zu minimieren. Als besonders nachhaltig sind Maßnahmen anzusehen, die zu einer Minimierung der endokrin wirksamen Substanzen an der Quelle der Anwendung bzw. der Emission führen (Moltmann et al. 2007). So wäre z.B. ein Abwassermonitoring mit entsprechenden Behandlungsmethoden wünschenswert und im Sinne einer Erreichung eines geforderten guten ökologischen Zustandes nach der europäischen Wasserrahmenrichtlinie. Aktuelle Ergebnisse aus dem EU-Projekt Neptun weisen daraufhin, dass die Ozonung von Abwasser zumindest zu einer Reduzierung der Östrogenität führen kann und dabei in einem akzeptablen Kostenrahmen bleibt.

\section{Methoden}

2.1 Nachweismöglichkeiten hormonaktiver und reproduktionstoxischer Substanzen

Dieses Kapitel gibt einen Überblick über verschiedene, vorwiegend biologische Nachweismöglichkeiten hormonaktiver und reproduktionstoxischer Substanzen. Es stellt keine allumfassende Auswertung der wissenschaftlichen Studien zu diesen Themen dar, da dies den Rahmen sprengen würde.

Von den mehr als 100000 Chemikalien, die in der europäischen Liste der existierenden Chemikalien geführt werden (Commission of the European Comunities 1996) sind nur für wenige Substanzen überhaupt Daten für endokrine Wirkungen erhoben worden und nur für einige kann überhaupt eine potenzielle östrogene Aktivität angegeben werden. Daher ist anzunehmen, dass für eine unbekannt hohe Anzahl an Substanzen und auch deren Metabolite und Derivate eine endokrine Aktivität besteht, die derzeitig nicht quantifiziert werden kann, weil die nötigen Studien und allgemein akzeptierte Methoden fehlen. Es wird deutlich, dass neben den sich kontinuierlich entwickelnden analytischen Verfahren weitere integrative Detektionsmöglichkeiten für hormonaktive Wirkungen entwickelt und eingesetzt werden sollten. Im folgenden Abschnitt sollen daher verschiedene Nachweismöglichkeiten für endokrine Disruptoren und hormonaktive Substanzen mit ihren wesentlichen Vor- und Nachteilen beschrieben werden.

\subsection{Der chemisch-numerische Ansatz zur Erfassung von Belastungen und strukturbezogene Vorhersagemodelle}

Eine chemische Analyse gibt Aufschluss über die stoffliche Natur einer Belastung. Ihre Aussagekraft bleibt auf die gemessenen Parameter (Konzentration, Gehalt, selten auch die Speziation) beschränkt und sagt nichts über den $\mathrm{zu}$ erwartenden endokrinen Effekt aus, insbesondere bei Substanzen, deren mögliche endokrine Aktivität noch nicht untersucht wurde. Aus einer Vielzahl von Probeninhaltsstoffen kann meist nur ein kleiner Teil gemessen werden. Die analytischen Verfahren, mit denen Substanzen mit bekannter östrogener Aktivität in Umweltproben nachgewiesen werden können, werden kontinuierlich weiterentwickelt (Desbrow et al 1998, Spengler et al 2001). Neuere Studien weisen daraufhin, dass es gute Korrelationen zwischen den Ergebnissen von analytischen Verfahren für bekannte hormonaktive Substanzen und In-vitro-Ansätzen für Abwasseruntersuchungen gibt (Nelson et al 2007, Leusch 2008). Für den Fall, dass man die Struktur eines Stoffes kennt und seine Wirkung vorhersagen möchte, gibt es mittlerweile Vorhersagemodelle. Ein Instrument ist die quantitative Struktur-Wirkungs-Beziehung (QSAR). Hierbei wird eine quantitative Beziehung zwischen einer physikalischen, chemischen oder biologischen Wirkung eines Stoffes zu seiner Struktur erstellt und berechnet. Neuere Weiterentwicklungen des QSAR, wie z.B das VirtualToxLab ermöglichen es für verschiedene Substanzen die Bindung an verschiedenen Rezeptoren vorherzusagen (Vedani et al 2008).

Bei all diesen Entwicklungen sollte berücksichtigt werden, dass ein toxikologisches und endokrines Potenzial 
nur bei ausreichender Kenntnis der Schadstoffe sowie deren gegenseitiger Beeinflussung abgeschätzt werden kann. Die Zahl der im Oberflächen- und Abwasser eingetragenen und teilweise auch gezielt eingesetzten Einzelsubstanzen liegt auch in der Größenordnung um 100000 (Pluta 2008a). Aufgrund der stofflichen Vielfalt der Substanzen und deren vielfältige Wirkungsrichtungen ist eine Erweiterung des chemisch-numerischen Ansatzes um eine ökotoxikologische Gefahrenpotenzialabschätzung unausweichlich. Die ökotoxische Wirkung eines Stoffes ist abhängig von seinen chemisch-physikalischen Eigenschaften, seiner Dosis, der Expositionsdauer, dem Expositionszeitpunkt sowie seiner Aktivität und Bioverfügbarkeit. In der Regel sind daher eine Kombination von analytischen und ökotoxikologischen Ansätzen für eine wirkungsorientierte Betrachtung zu bevorzugen, da diese eine integrale oder summarische Wirkungserfassung ermöglichen und auch Mischungstoxizitäten von Schadstoffen berücksichtigen können.

\subsection{Biologische Nachweisverfahren und ökotoxikologische Ansätze}

Biologische Verfahren können die analytisch nicht erfassten oder nicht erfassbaren Kontaminanten anhand ihrer Schadstoffwirkung anzeigen, dabei ermöglichen sie aber keinen quantitativen oder qualitativen Stoffnachweis. Mit biologischen Testverfahren können sowohl ökotoxikologische Wirkungen von Einzelstoffen (agonistische/induzierende und antagonistische/inhibierende) als auch Kombinationswirkungen (additive, synergistische, aber auch kompetitive und inhibitorische Effekte) aller vorhandenen Kontaminanten erfasst werden. Diese integrative Erfassung von Schadstoffwirkungen macht die ökotoxikologische Untersuchung als Entscheidungshilfe für ein Umweltmanagement unentbehrlich (Krebs 2001). Bei der Vielfältigkeit ökotoxikologischer Ansätze zur Bestimmung der hormonaktiven Wirkungen lassen sich zwischen In-vitro- und In-vivo-Testverfahren unterscheiden.

\subsubsection{In-vitro-Testverfahren}

In-vitro-Testverfahren sind suborganismische Testverfahren, die zelluläre oder subzelluläre Systeme benutzen. Sie erfassen die Wirkungen von Einzelstoffen, Stoffgemischen oder Umweltproben auf isolierte Teile von Organismen (Gewebe, Zelle, Zellkompartimente und Biomoleküle) unter Laborbedingungen. Sie dienen der Erfassung von biologischen Wirkungen auf zellulärer, molekularer und biochemischer Ebene und vermögen primär kurzfristige und direkte ökotoxikologische Wirkungen anzuzeigen. Mit ihnen können vielfältig gerichtete Wirkungen angezeigt werden (pro Testverfahren aber meist nur eine oder wenige), deren Mechanismen biologisch so elementar sind, dass sie für mehrere Organismengruppen gleichzeitig Wirkpotenziale aufzeigen können. Abbildung 1 soll einen Überblick über die Vielfältigkeit und die Ansatzpunkte von In-vitro-Biotestverfahren für eine Erfassung hormonaktiver Wirkungen geben.

Ein wesentlicher Nachteil dieser Testsysteme beruht in der begrenzten Übertragbarkeit der Untersuchungsergebnisse auf die relevanten Gesamtorganismen, denn nicht alle möglichen Wirkungspotenziale (z. B. durch Bioakkumulation und Bioaktivierung von Schadstoffen) können mit In-vitro-Verfahren abgebildet werden (Leusch 2008). So werden z.B. organismische Low-dose-Effekte, die nur über lange Expositionszeiten nachgewiesen werden können, nicht erfasst. Ebenso werden kritische Expositionszeitpunkte in der Ontogenese von Organismen nicht berücksichtigt.

Doch sind auch komplexe ökotoxikologische Wirkungen auf Organismenebene letztlich auf eine Kombination von molekularen und biochemischen Wirkungsmechanismen zurückzuführen, und so besitzen einige dieser Verfahren einen hohen Indikationswert für eine hormonelle Aktivität. Zudem ist der Nachweis direkter Wirkungen durch suborganismische Testsysteme weniger stark durch Störanfälligkeit und Variabilität organismischer Testverfahren limitiert, was den detektierbaren Konzentrationsbereich für Ursache-Wirkungs-Beziehungen erweitert.

So können mit molekularbiologischen Methoden auch Reportergene in Zellen transfiziert werden, die bei einer Bindung von hormonaktiven Stoffen an Rezeptoren exprimieren und so z. B. über eine Enzymaktivität ein messbares Signal erzeugen (Tabelle 1). Insgesamt stellen die In-vitro-

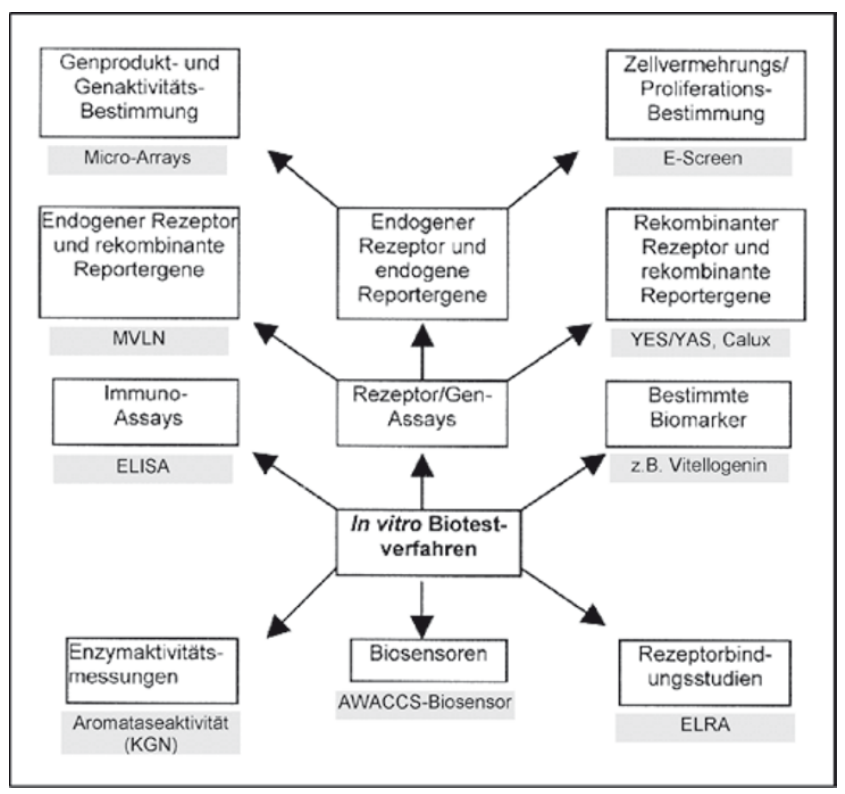

Abb. 1 In-vitro-Testverfahren zur Bestimmung von hormonaktiven Wirkungen (verändert nach Kase 2004); Beispiele wurden grau hinterlegt und werden im Verlauf des Manuskriptes erläutert. Ebenfalls stellt die Modulation Steroidgenese eine Angriffsfläche für endokrine Disruptoren dar, die in vitro erfasst werden kann 


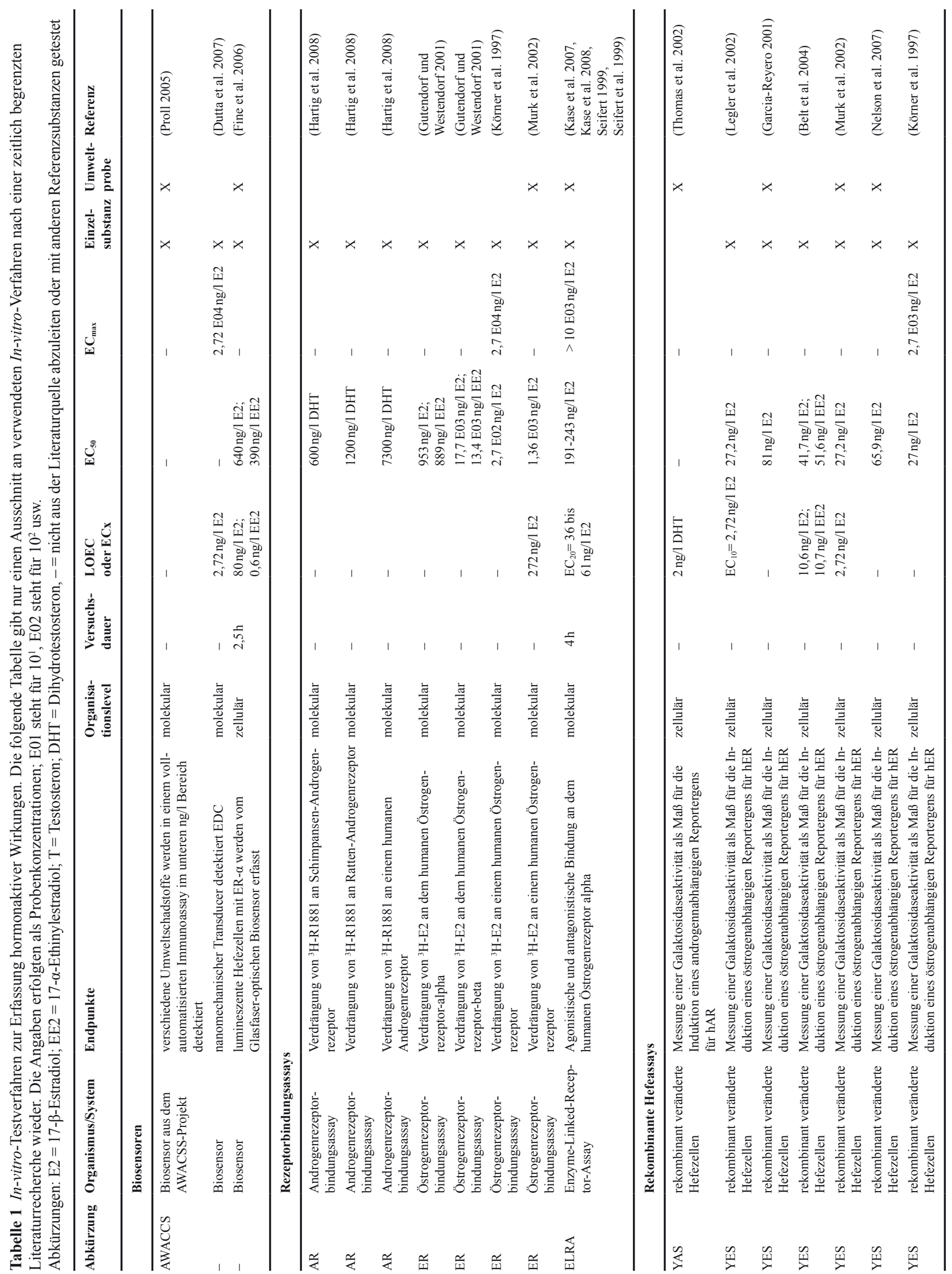




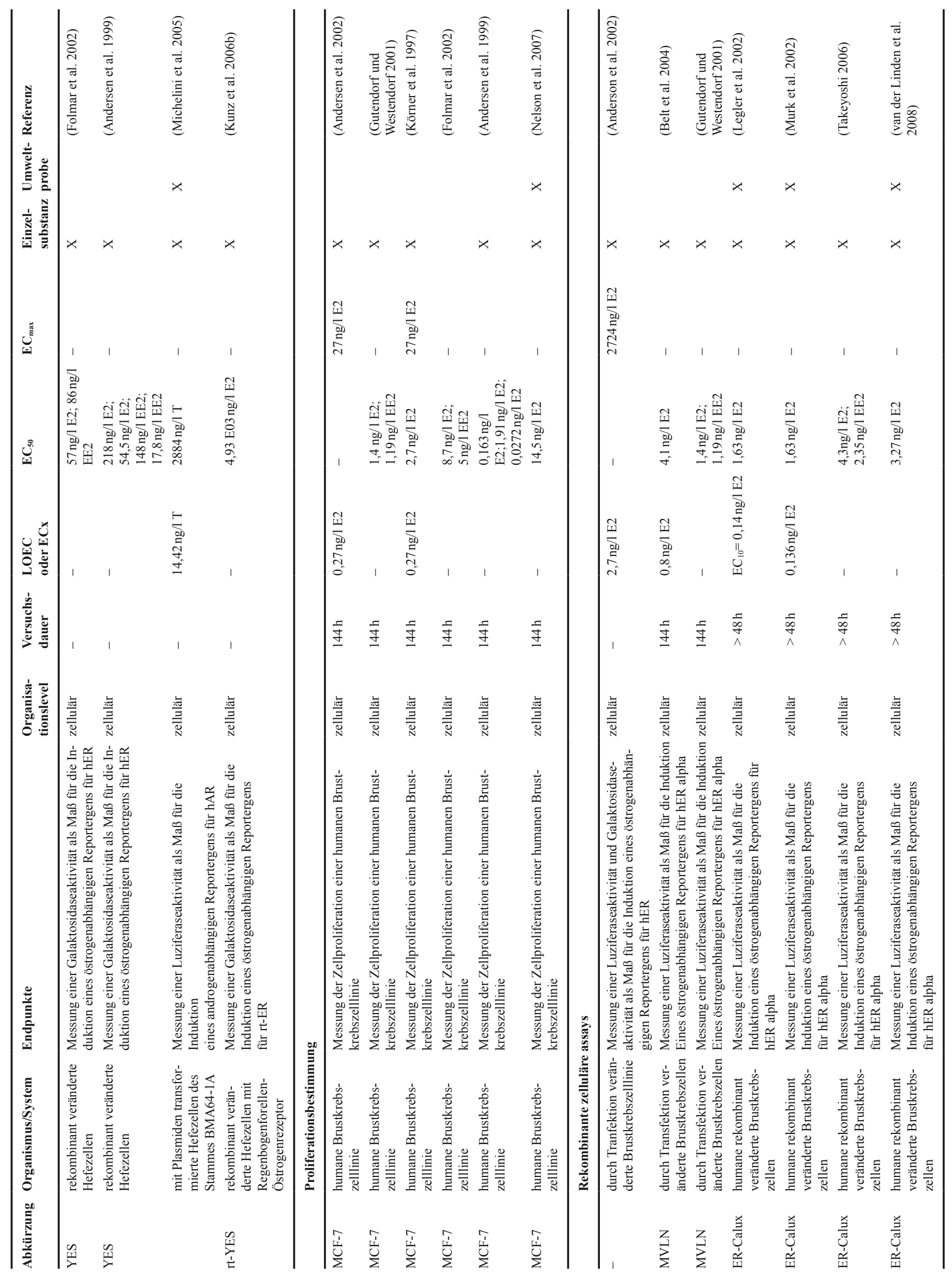




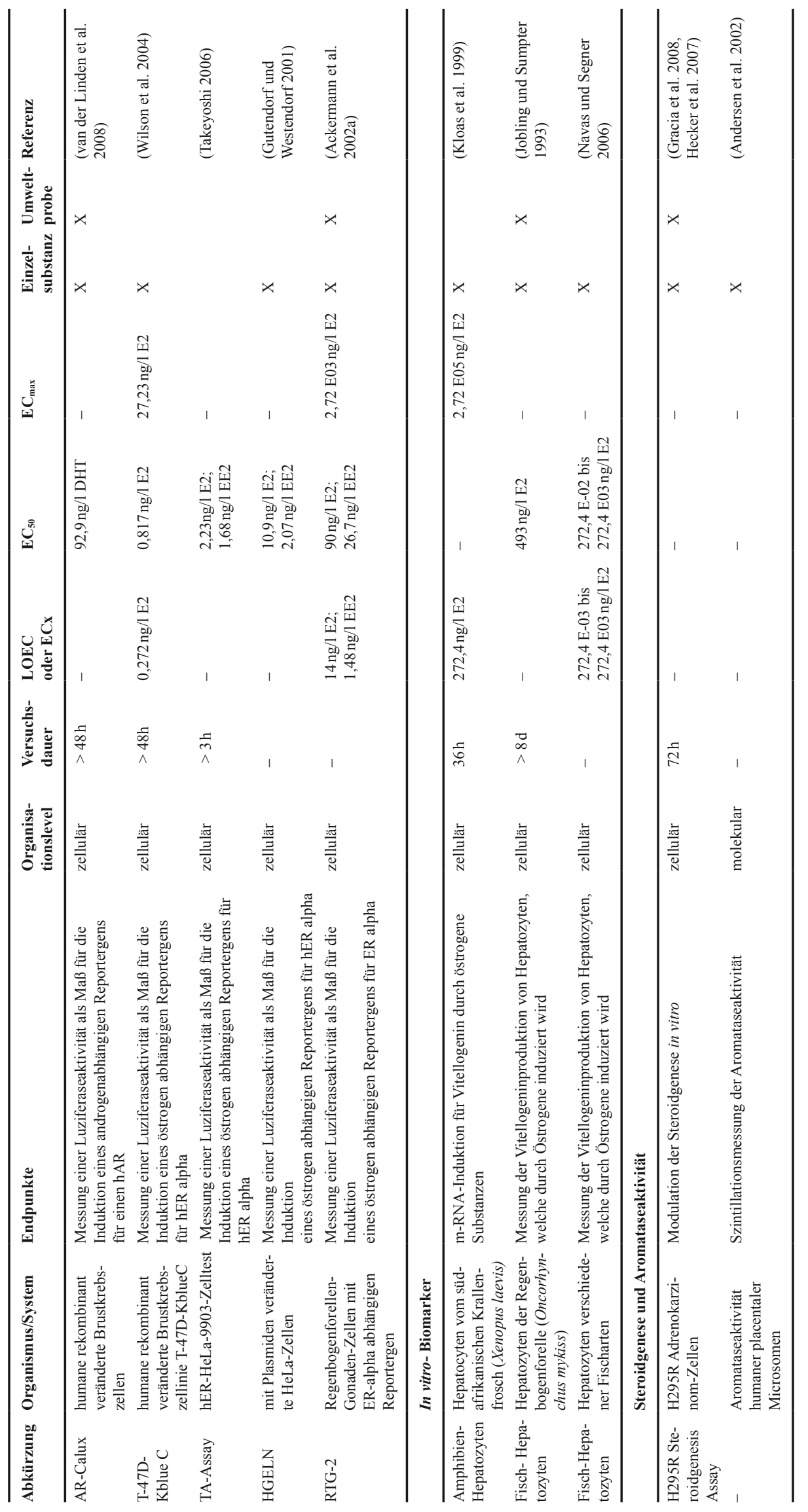


Testsysteme eine schnelle und wirtschaftliche Ergänzung zu den In-vivo-Testsystemen dar, besonders wenn es um ein wirkmechanistisches Screening des toxikologischen Potenzials für Umweltproben geht. Eine Vorraussetzung sollte sein, dass diese In-vitro-Tests relativ sensitiv sind und ohne aufwändige und die Bioverfügbarkeit verändernde Probenvorbereitungen einsetzbar sind. Ein Großteil der verwendeten In-vitro-Verfahren beruht auf Östrogenrezeptorvermittelten Antworten, die sich als Screening-Verfahren für Xenoöstrogene eignen (Ankley et al. 1997; Nelson et al. 2007; Zacharewski 1997). In-vitro-Testverfahren haben sich als sensitive Methoden für eine Bewertung der hormonaktiven Wirkungen bewährt und erlauben quantitative Abschätzungen der Aktivität von beispielsweise partiellen rezeptorvermittelten Antworten (Hollert et al. 2005). Auch nicht rezeptorvermittelte Wirkmechanismen wie Modulationen der Aromataseaktivität (Andersen et al. 2002) oder der Steroidgenese (Gracia et al. 2008; Hecker et al. 2007a) können mit In-vitro-Verfahren erfasst werden. Ergänzend zu der Auflistung in Tabelle 1 gibt es einen Literatur-Review (Global Water Research Coalition 2006) über In-vitro-Biotests, der insgesamt 24 Testverfahren (3 Rezeptorbindungsassays, 5 rekombinante Hefeassays, 9 rekombinante Säugerzellen-Reporter-Testverfahren, 1 rekombinanten Fischzellen Reporter-Testverfahren, 4 Genexpressionsverfahren und 2 Zellproliferationsassays) auflistet und bewertet. Ebenfalls gibt es einen Vergleich von In-vitro-Verfahren von der Danish-EPA (Kinnberg 2003), der Rezeptorbindungsassays, Reportegeneassays und den E-Screen (Zellproliferationsassay) beschreibt und bewertet.

Biosensoren können zu den In-vitro-Verfahren gezählt werden und sind bioanalytische Systeme, die mit biologischen Komponenten ausgestattet sind. Biosensoren basieren auf der direkten räumlichen Kopplung eines immobilisierten biologisch aktiven Systems mit einem Signalumwandler (Transduktor) und einem elektronischen Verstärker. Für die Erkennung der zu bestimmenden Substanzen nutzen Biosensoren biologische Systeme auf unterschiedlich hohem Integrationsniveau. Solche biologischen Systeme können z. B. Antikörper, Enzyme, Organellen oder Mikroorganismen sein. Das immobilisierte biologische System des Biosensors tritt in Wechselwirkung mit dem Analyten (Eggins und Brian 2002, Gerhardt 1999). Beispiele für Biosensoren im Zusammenhang mit dem Nachweis von hormonaktiven Substanzen stellen Multianalytbestimmungen über Immunoassays (Proll 2005) oder integrale Rezeptorbindungserfassungen (Fechner et al. 2008) dar.

\subsubsection{Biomarker und Bioindikatoren}

Eine Zwischenstellung zu den In-vivo- und In-vitro-Testverfahren stellen einige Biomarkersysteme dar, die meist mit einer Exposition des gesamten Organismus arbeiten, aber nur einen physiologischen suborganismischen Parameter, wie z. B. eine Enzymaktivität, erfassen. Ein Biomarker ist ein molekularer, biochemischer, zellulärer oder physiologischer Parameter, der sich durch äußere Stressoren verändert. Depledge und Fossi haben 1998 den Begriff ausgeweitet und Biomarker auf verschiedenen biologischen und ökologischen Organisationsebenen definiert (Depledge und Fossi 1998). Dennoch können in einigen Fällen suborganismische Biomarker einen Indikationswert für Folgeeffekte auf organismischer oder vielleicht sogar auf populationsrelevanter Organisationsebene darstellen. So kann z. B. eine Hemmung der Aromatase (CYP 19) einer Cytochrom- $\mathrm{P}_{450}$-abhängigen Monooxygenase, die u.a. für die Umbildung von Testosteron zu Estradiol zuständig ist, eine Verschiebung des Geschlechtshormonspiegels bewirken. Eine Ausbildung von Imposexstadien steht bei bestimmten Gastropodenarten in Zusammenhang mit einer Exposition gegenüber Organozinnverbindungen, kann aber auch durch andere endokrine Disruptoren bewirkt werden (Schulte-Oehlmann et al. 2001). Bei Gastropoden wird die Ausbildung von Imposexstadien durch den Mechanismus der Aromatasemodulation parallel $\mathrm{zu}$ anderen Hypothesen diskutiert (Oehlmann et al. 2007). In Fischen kann die Modulation der Aromatasen CYP19a und CYP19b zu einer Beeinflussung der hormonellen Gleichgewichtslage führen, wobei die Aromataseregulation eine Schlüsselrolle in der sexuellen Differenzierung und der Reproduktion einnimmt (Cheshenko et al. 2008). Ebenfalls spielt sie eine wichtige Rolle in der Organogenese (Eggen 2008). Auch die Quantifizierung des Dottervorläuferproteins Vitellogenin in männlichen Fischen stellt einen Biomarker für östrogene und antiandrogene EDC-Belastungen dar (Hansen et al. 1998; Sumpter und Jobling 1995; Ankley et al. 2001; Routledge et al. 1998). Als Vorstufe des Eidotters ist Vitellogenin in juvenilen und männlichen Individuen nicht vorhanden, kann aber durch hormonaktive Stoffe induziert werden. Ebenfalls kann die Vitellogeninproduktion durch endokrine Substanzen in weiblichen Fischen unterdrückt werden. Eine Vitellogenin-Induktion kann durch einen ELISA (Enzyme-Linked Immonoassay) bestimmt werden (Tyler et al. 1999) oder die durch Transkription des Gens Vitellogenin entstandene mRNA (messenger ribonucleic acid) kann auch durch reverse Transkription mittels PCR quantifiziert werden (Lattier et al. 2002). Der Vitellogenin-Test wird in der Literatur als In-vivo-Test-Endpunkt angegeben; wenn er hingegen an primären Hepatozyten durchgeführt wird, handelt es sich um einen In-vitro-Test-Endpunkt (Jobling und Sumpter 1993; Hollert et al. 2005). Die Übergänge der Teststrategien sind fließend (Abb. 2).

Eine Kombination von Biomarkern wie die mRNAInduktion von Vitellogenin aus Regenbogenforellen (Oncorhynhus mykiss), die in situ in Kläranlagenausläufen exponiert wurden, mit dem In vitro Yeast Estrogen Screen Assay (YES, mit humanem Östrogenrezeptor (ER)), HEK293- 


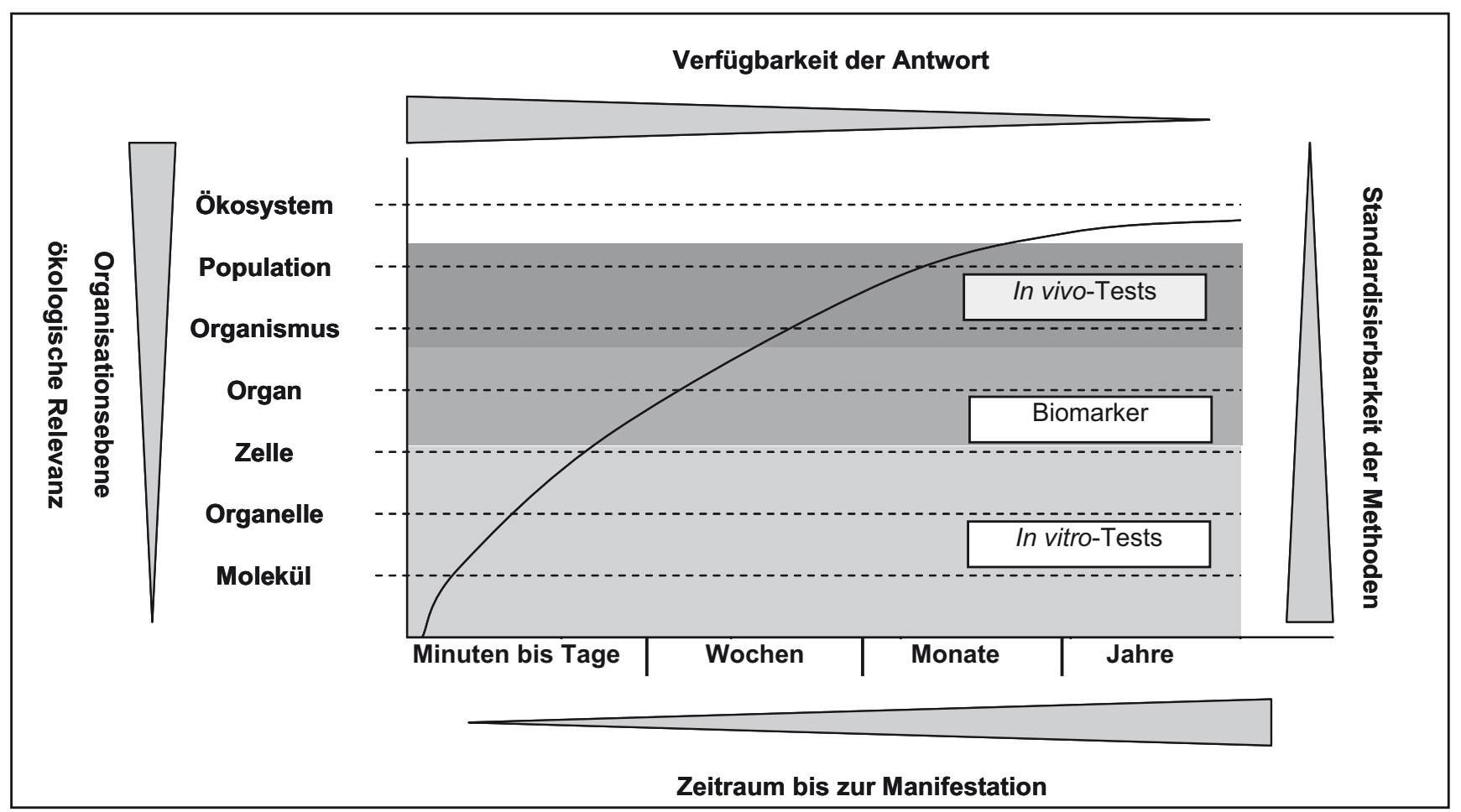

Abb. 2 Ebenen der ökotoxikologischen Wirkungen und mögliche Dauer der Manifestation von Effekten in Abhängigkeit der Untersuchungsmethodik (verändert nach Braunbeck 1993)

Zellen (Human Embryonic Kidney cells mit ER) und der In-vitro-Vitellogenininduktion in primären Regenbogenforellen-Hepatozyten, ergab gute Korrelationen für die Bewertung einer östrogenen Aktivität (Pawlowski et al. 2003). Die Sensitivitätsreihenfolge der Testverfahren schwankte jedoch für die einzelnen Erfassungszeiträume. Eine gute Übersicht beispielsweise über den Biomarker Vitellogenin in Fischen und deren primären Hepatozyten bieten die Arbeiten von Hutchinson und Navas (Hutchinson et al. 2006; Navas und Segner 2006), diese zeigen aber auch die große Variationsbreite der Antwort.

Als weitere Biomarker können benutzerdefinierte Genexpressionsanalysen einzelner Gene oder von tausenden von Genen mittels cDNA Arrays (complementary DNA; Microarrays, Genchips) genutzt werden. Beispielsweise sind Genexpressionsanalysen unter Östrogeneinfluss an primären Hepatozyten der Regenbogenforelle möglich und erlauben deren Einsatz als In-vitro-Modell in der Ökotoxikologie (Schreer 2005). Der MolDarT (Muncke 2008) ermöglicht eine selektive Aussage über die Induktion von östrogenabhängigen Genen in Fischeiern vom Zebrabärbling (Danio rerio), z.B. für den Biomarker Vitellogenin. Eine signifikante Vitellogenininduktion konnte für östrogene Substanzen (bei $25 \mathrm{ng} / 1$ für 17-alpha-Ethinylestradiol und 2,7 $\mu \mathrm{g} / 1$ für 17-beta-Estradiol) nachgewiesen werden (Muncke et al. 2006). Ein Vergleich der Sensitivität für Einzelsubstanzen wurde tabellarisch zusammengefasst (siehe Tabelle 1).
Ebenso gibt es Microarray-Verfahren mit In-vivo-Ansätzen, die beispielsweise die Expression von 2000 Genen in adulten Pimephales promelas erfassen und zeigen, dass mindestens 71 Gene durch 17-beta-Estradiol-Einfluss reguliert werden (Larkin et al. 2007). Ein ähnliches Verfahren gibt es für den Zebrabärbling (Danio rerio) (Martyniuk et al. 2007). Auch Medaka (Oryzias latipes) wurde mit Hilfe von Microarrays auf androgene Substanzen untersucht, wobei insgesamt 1815 Gene von 9379 untersuchten Genen hoch- oder herunterreguliert wurden und 50 diagnostische Gene identifiziert werden, die charakteristische Genexpressionsprofile unter Androgeneinfluss aufweisen (Leon et al. 2008). Genexpressionsanalysen haben den Vorteil, dass diverse endokrine (östrogen, androgen, thyroidal usw.) und andere chronische Effekte (z.B. Neuro- oder Immunotoxizität) gleichzeitig untersucht werden können und so ein gesamtheitliches Bild einer Expositionswirkung entsteht. Geeignete Auswertungsmethoden werden entwickelt, um solch umfangreiches Datenmaterial aus Microarrays zu interpretieren. Da es sich um Effekte auf Transkriptionsebene handelt, bedarf es auch noch weiterer Anstrengungen diese Effekte auf höhere organismische Ebenen zu übertragen und als zuverlässige Indikatoren für die vielfältigen Ausprägungen einer endokrinen Disruption zu nutzen. Ebenfalls ist bei solchen Extrapolationen zuvor die ökotoxikologische Relevanz der Aussage abzuklären, was oft schwierig ist, da die Variabilitäten bei einigen Biomarkern art- und entwick- 
lungsspezifisch sehr ausgeprägt sein können. Es müssen daher noch eindeutige Bewertungskriterien und Endpunkte eingeführt werden.

\subsubsection{In-vivo-Testverfahren}

In-vivo-Testverfahren sind biologische Testverfahren, bei denen Organismen in definierter Art und Anzahl eingesetzt werden, um deren Reaktion auf eine Exposition zu messen. Sie nutzen den gesamten Organismus und basieren meist auf der Erfassung von Veränderungen an morphologischen, physiologischen oder verhaltensbiologischen Merkmalen. In-vivo-Tests besitzen eine sehr hohe Aussagekraft, da sie die Reaktion des gesamten Organismus auf Umwelteinflüsse integriert erfassen (Spengler 2001). Leider zeichnen sich In-vivo-Tests je nach Testparameter meist durch eine längere Versuchsdauer, besonders bei chronischen Tests (siehe Abb. 4), und einen hohen Arbeitsaufwand aus. Um ein valides Ergebnis zu erhalten muss eine ausreichende Anzahl an Versuchstieren parallel getestet werden.

Kommt es sowohl bei Umweltproben- als auch bei Einzelsubstanztestungen zu Überlagerungen von toxischen und hormonaktiven Effekten, sind in einigen Fällen RangeFinding-Versuche notwendig, da endokrine Effekte deutlich geringere Schwellenwerte aufzeigen können als verschiedene andere Effektparameter. Auch können meist nur wenige Konzentrationen oder Verdünnungsstufen parallel getestet werden.

Den methodischen Nachteilen von In-vivo-Tests steht eine direkte Interpretierbarkeit der Versuchsergebnisse für den Organismus, teilweise sogar für die Population, also insgesamt eine höhere ökologische Aussagemöglichkeit gegenüber. Prinzipiell ist es möglich mit In-vivo-Ansätzen bei genügend langer Expositionszeit auch Effektkaskaden, verzögerte und chronische Effekte und Wirkungen von Low-dose-Substanzen nachzuweisen. Ebenso können Kombinationseffekte, sekundäre Effekte und auch Metabolisierungseffekte angezeigt werden. Insgesamt können mehrere relevante Parameter einer organismischen Antwort über den Versuchszeitraum aufgenommen werden (Schäfers 2007) und verschiedene Wirkmechanismen erfasst werden. Bestimmte Substanzen wie Nonylphenol können z. B. Biomarker wie die Vitellogenin-Induktion in Regenbogenforellen (Oncorhynchus mykiss) beeinflussen, aber wirken sich nicht direkt auf morphologische Parameter und Geschlechterverhältnisse aus (Ackermann et al. 2002b). Ebenfalls erweist sich eine Korrelation der Vitellogenin-Konzentrationen und der gonadosomatischen Indexes (GSI) in Fischen als schwierig, wie es an Goldfischen (Carassius auratus) gezeigt werden konnte (Li et al. 2008).

Im Gegensatz dazu konnte jedoch in diversen Arbeiten gezeigt werden, dass bespielsweise in reproduzierenden männlichen Dickkopf-Elritzen die VTG-Produktion gut mit Gonaden-Histopathologie und sekundären Geschlechtsmerkmalen korreliert (Weisbrod et al. 2007; Kunz et al. 2006a; Harries et al. 2000; Miles-Richardson et al. 1999) und in reproduzierenden Weibchen auch mit der Fekundität, Gonaden Histologie und GSI übereinstimmt (Ankley et al. 2001; Kunz et al. 2006a; Weisbrod et al. 2007). Zusätzlich zu den östrogenen Effekten können z.B. androgene oder antiöstrogene Effekte durch eine Verringerung des VTGLevels in weiblichen Fischen oder auch mit einem Rückgang der Fekundität angezeigt und korreliert werden. Die Untersuchungsmöglichkeiten androgener und antiandrogener Substanzen wurden auch an heimischen Arten wie dem Rotauge (Rutilus rutilus) bewertet (Ballegooy 2008). Bei der Anwendung für ein Umweltmonitoring sollte jedoch in Betracht gezogen werden, dass je nach untersuchter Art die Messparameter saisonalen Schwankungen im Reproduktionszyklus unterliegen können und möglichst heimische Arten verwendet werden sollten. Neuere Testverfahren, die sich derzeit in Validierung befinden, wie beispielsweise der Reproduktionstest mit der limnischen neuseeländischen Zwergdeckelschnecke (Potamopyrgus antipodarum), können reproduktionstoxische und hormonaktive Wirkungen durch Reduzierungen oder Stimulationen der Embryoproduktion anzeigen (Duft et al. 2007) und reagieren in umweltrelevanten Konzentrationen auf vielfältige androgene und östrogene Substanzen. Andere Schneckenarten wie Marisa cornuarietis oder Nassarius reticulatus reagieren ähnlich sensitiv und vermögen EDC-Wirkungen wahrscheinlich stärker über den Mechanismus der Aromatasehemmung und die Ausbildung von Imposexstadien anzuzeigen. Auch könnten andere Invertebraten, wie beispielsweise Bachflohkrebse (z. B. Gammarus pulex) in Zukunft für die Untersuchung von endokrinen Disruptoren genutzt werden, und erste Studien zeigen, dass Endpunkte wie Geschlechterverteilung, Gonadenhistologie, Vitellogenin und das HeatShock-Protein 90 (Gagné et al. 2005; Gross et al. 2001; Schirling et al. 2006; Watts et al. 2002) geeignet sein könnten. Die Verwendung von Invertebratenarten, welche eine Schlüsselrolle im aquatischen Ökosystem ausüben, erlaubt es die ethisch umstrittenen Fischtests einzuschränken und gleichzeitig Biotests durchzuführen, die ökologisch relevant sind. Eine Erfassung möglichst vielfältiger Endpunkte in In-vivo-Tests mit unterschiedlichen Arten ist daher sinnvoll und sollte unter möglichst standardisierten Bedingungen durchgeführt werden.

Mögliche Endpunkte zur Erfassung von endokrin wirksamen Substanzen mit In-vivo-Tests sind:

- Physiologische Veränderungen: Vitellogeninkonzentrationen (Ackermann et al. 2002b; Hansen 2000; Kang et al. 2002; Kunz und Fent 2006, 2009; Li et al. 2008; OECD 2006a; Routledge et al. 1998; Segner et al. 2003), 11-Keto-Testosteron (Schäfers 2007), Spiggin-Konzentrationen (Katsiadaki et al. 2002) oder andere physiolo- 
gisch relevante Hormonkonzentrationen (Kloas 2002), Thyroidstoffwechsel (Kloas 2002), Aromatasehemmung (Cheshenko et al. 2008; Oehlmann et al. 2007);

- Morphologische Veränderungen der primären oder sekundären Geschlechtsmerkmale: Geschlechtsdifferenzierungen (Duft et al. 2007; Kloas et al. 1999; OECD 2006a), sekundäre Geschlechtsmerkmale (Kunz et al. 2006a; Weisbrod et al. 2007), Gewicht und Körpermaße der Geschlechtsorgane (Duft et al. 2007; Schulte-Oehlmann et al. 2001; Weisbrod et al. 2007), gonadosomatischer Index (GSI) (Baatrup und Junge 2001; van den Belt et al. 2004; Kang et al. 2002; Li et al. 2008; OECD 2006a; Segner et al. 2003), Gonadenhistologie (Kunz et al. 2006a; Miles-Richardson et al. 1999; Pawlowski et al. 2004; Weisbrod et al. 2007) oder Spermienzählungen (Baatrup und Junge 2001), Intersexstadien (Metcalfe et al. 2001; Schulte-Oehlmann et al. 2001), Imposexstadien (Duft et al. 2007; Oehlmann et al. 2007);

- Reproduktionstoxikologische Parameter:

Ei-oder Embryozahlen (Ankley et al. 2001; Duft et al. 2007; Kang et al. 2002; Kunz et al. 2006a; Weisbrod et al. 2007), Befruchtungshäufigkeiten (Ankley et al. 2001; Kang et al. 2002; Schäfers und Wenzel 2000), Larvalentwicklungen (Andersen et al. 2001; Ankley et al. 2001; Kloas 2002; Nishimura et al. 1997), Reproduktionserfolge (Kang et al. 2002; Preston et al. 2001), Geschlechterverhältnisse (Ackermann et al. 2002b; Kloas et al. 1999; Kloas 2002) und Paarungsverhalten von Fischen (Coe et al. 2008; Watts et al. 2001).

Auf In-vivo-Testverfahren wird teilweise in Tabelle 4 eingegangen. Eine wesentlich umfangreichere Zusammenstellung der In-vivo-Testverfahren befindet sich bei Moltmann et al. (2007) und soll hier nicht aufgeführt werden.

\section{Ergebnisse}

3.1 Problematik einer Testauswahl nach einer Literaturrecherche

Eine Bewertung der In-vivo-Testverfahren erweist sich als schwierig, zumal einzelne In-vivo-Verfahren aufgrund des experimentellen Aufwands und der meist geringeren Verbreitung eine geringere Datendichte aufweisen. Ebenfalls können die In-vivo-Sensitivitäten aufgrund der Unterschiedlichkeit der Referenzsubstanzen und der Vielzahl der untersuchten Endpunkte nicht vergleichend dargestellt werden. Zusätzlich erschwerend kommt hinzu, dass es international Bestrebungen gibt, bewilligungspflichtige Tierversuche zukünftig wo möglich zu vermeiden und durch nichtbewillingspflichtige In-vivo-Versuche mit Invertebraten oder mit In-vitro-Testsystemen zu ersetzen. Ein Anliegen dieser Arbeit ist es diese Entwicklungen zu berück- sichtigen und wo möglich bewilligungsfreie Testsysteme vorzuschlagen.

Auch bei der Auswahl und Bewertung möglicher geeigneter In-vitro-Verfahren sind nach einer Literaturrecherche viele Fragen offen (siehe Tabelle 1). An Beispielen mit subzellulären und zellulären In-vitro-Testverfahren sollen hier kurz die Probleme für eine Einschätzung von Testverfahren erörtert werden, die zunächst nicht ersichtlich sind:

Beispiel 1 Jedes zelluläre Testverfahren hat durch seine Sensitivität gegenüber hormonaktiven Wirkungen und durch seine Empfindlichkeit gegenüber toxischen und konzentrationsbedingten Effekten einen eigenen Arbeitsbereich, in dem es Wirkungen anzuzeigen vermag. Abbildung 3 zeigt eine typische Östrogenrezeptor-vermittelte Antwort eines zellulären Systems, die in bestimmten Konzentrationsbereichen zytotoxischen oder konzentrationsbedingten Effekten unterliegt.

Konsequent sollten bei der Anwendung von zellulären Verfahren toxische Effekte sorgsam von östrogenen Effekten unterschieden werden und nur in Konzentrationen und Verdünnungen benutzt werden, in denen die Zellvitalität kaum beeinflusst wird (Kinnberg 2003). Eine Probenverdünnung reduziert die Toxizität, aber ebenfalls die Möglichkeit östrogene Effekte zu detektieren. Molekulare Rezeptorbindungsassays können daher zuverlässige Alternativen bei sich überlagernden Effekten sein. Der EnzymeLinked-Receptor Assay (ELRA) zählt zu den einfachsten, und mit einer Versuchsdauer von ca. 4 Stunden auch zu den schnellsten subzellulären Testsystemen (Hock und Seifert 1998). Eine störende Überlagerung mit zytotoxischen Effekten oder mikrobiellen Kontaminationen wie in zellulären oder organismischen Systemen wird vermieden (Kase et al. 2007). Eine Unterscheidung zwischen Agonisten und

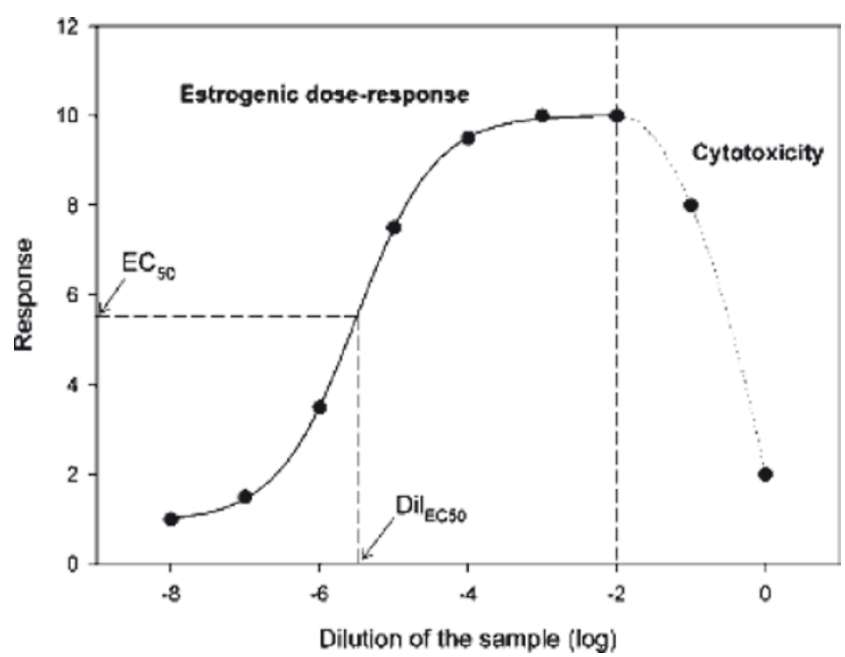

Abb. 3 Östrogenabhängige Antwort eines zellulären Biotests (aus Leusch 2008) 
Antagonisten ist bei keinem zellulären (z.B. YES oder ER-Calux) und subzellulären Testverfahren, welches auf einer Rezeptorbindung basiert, vollständig möglich, auch wenn es dafür experimentelle Ansätze gibt. So wird in zellulären Systemen der überwiegende Effekt zwischen östrogener und antiöstrogener Rezeptorbindung angezeigt, d.h. antiöstrogene Substanzen können östrogene Wirkstoffe in Umweltprobenmessungen überlagern, ohne dass es zu einer Zellantwort kommt. In subzellulären Rezeptorbindungsassays (z. B. ELRA) kann hingegen alles, was an den Rezeptor bindet, detektiert werden, unabhängig von seiner Wirkrichtung. Eine Anwendbarkeit auf Umweltproben mit verschiedenen Rezeptorbindungstests mit ausreichender Sensitivität konnte ebenfalls wie in anderen Studien bestätigt werden (Kase et al. 2008, Leusch et al. 2006, Murk et al. 2002). Rezeptorbindungsassays wie der ELRA sind ausreichend sensitiv, um sie in bestimmten Umweltprobenbewertungen ohne Aufkonzentrierungen in hohen Verdünnungsstufen anzuwenden (Kase et al. 2008). Ob dies auch für Oberflächengewässerproben zutrifft ist unklar und wird derzeitig an der University of Virginia in einer großen Messkampagne (ca. 200 Proben) geprüft. Die Sensitivität kann durch eine luminometrische Variante aber nochmals um den Faktor 5 gesteigert werden (Global Water Research Coalition 2006). Die Sensitivität für Einzelsubstanzen liegt jedoch meist unter denen von empfindlichen zellulären Systemen (siehe Tabelle 1). Aufgrund der fehlenden Wirkrichtungsunterscheidung eignen sich subzelluläre Rezeptorbindungsassays eher als Alternativen zu zellulären Systemen, wenn zytotoxische oder mikrobielle Belastungen in Umweltproben vorliegen.

Beispiel 2 In der Regel werden nach einer Literaturrecherche die bereits seit längerer Zeit etablierten Testverfahren auffallen, über die entsprechend umfangreich publiziert worden ist. Ein gutes Beispiel stellt der E-Screen oder auch MCF-7-Zelllinienproliferationstest dar, der sehr empfindlich östrogene Wirkungen an humanen Brustkrebszellen nachzuweisen vermag (Andersen et al. 1999; Gutendorf und Westendorf 2001; Folmar et al. 2002; Körner et al. 1997). Der MCF-7-Test als Proliferationstest wurde erstmalig 1995 von A. Soto in (Soto et al. 1995) mit 17-beta-Estradiol als Referenzsubstanz beschrieben. Auch konnte in dieser Studie bereits ein Screening für mehrere umweltrelevante östrogene Substanzen durchgeführt werden. Nur vereinzelte Literaturquellen weisen auf die methodischen Grenzen im Umgang mit diesem Testverfahren hin, wozu die Berücksichtigung initialer Zelldichten und die Verwendung hormonfreier oder hormonhaltiger Kulturmedien gehören. Beide Faktoren wirken sich erheblich auf die Sensitivität des Testverfahrens aus (Rasmussen und Nielsen 2002). Auch besteht bei längerem Einsatz von Zelllinien die Gefahr der Bildung von Subclonen, die veränderte Eigenschaften aufweisen. In einer Studie zum Interlaborvergleich des MCF7-Tests bei Verwendung des gleichen Zellstammes und des gleichen Protokolls traten Abweichungen für den $\mathrm{EC}_{50}$ bis zu einem Faktor von 70 auf (Andersen et al. 1999). Ein weiterer negativer Aspekt für den Einsatz des MCF-7-Testes als ökotoxikologisches Testsystem ist der direkte Einfluss von zytotoxischen Schadstoffen auf die Proliferationsrate, die als Maß für östrogene Aktivität dient (Kase 2004). In einigen Fällen ist es daher nicht möglich, zytotoxische Effekte von den hormonaktiven Wirkungen getrennt zu detektieren. Es bleibt zu prüfen, ob Weiterentwicklungen des MCF-7Tests wie der MVLN-Test (van den Belt et al. 2004, Gutendorf und Westendorf 2001), bei dem ein Reportergensystem integriert wurde, unabhängiger von zytotoxischen Effekten östrogene Effekte anzeigen kann, z. B. indem Wachstumsund Induktionseffekte miteinander verrechnet werden.

Für ein Umweltmonitoring sind z.B. Testverfahren zu bevorzugen, die mit möglichst nativen Proben arbeiten können, damit die natürlichen Expositionspfade, aber auch der Einfluss der Bioverfügbarkeit berücksichtigt werden können. Erfreulicherweise gibt es vergleichende Studien (Kase et al. 2007; Legler et al. 2002; Leusch et al. 2006; Leusch 2008; Murk et al. 2002), die es sich zur Aufgabe gemacht haben, die für eine Anwendung relevanten Kriterien $\mathrm{zu}$ identifizieren und $\mathrm{zu}$ bewerten. Am besten eignen sich Studien, die sowohl mit Einzelsubstanz- als auch mit Umweltprobenuntersuchungen gearbeitet haben.

Eine Bewertung des E-screens oder des MCF-7-Proliferationstests kann je nach gesammelten Erfahrungen durchaus unterschiedlich ausfallen (Tabelle 2).

Beispiel 3 Auch die Einschätzung des YES, als nicht sensitives Verfahren, kann durch Literaturangaben widerlegt werden, da er schon mehrfach erfolgreich für Umweltprobenbewertungen eingesetzt wurde (siehe Tabelle 1). Die hier verwendeten YES-Verfahren hatten eine Nachweisgrenze von 3,5 und $5 \mathrm{ng} / 1$ 17-beta-Estradiol, andere YES-Verfahren können um den Faktor 10-50 sensitiver (zum Vergleich z.B. Vermeirssen et al. 2006). Es ist davon abhängig, welches YES-System in welcher Modifikation verwendet wird. Der Anspruch eines Anwenders an ein Testverfahren hängt aber stark vom Anwendungszweck ab.

\subsection{Erfassung relevanter Anwendungskriterien} für biologische Testsysteme

Nach dieser Literaturrecherche wurde aufgrund der oben geschilderten Problematik bei der Auswahl der Testverfahren ein Fragebogen entworfen, der möglichst unterschiedliche Anforderungen an ein Testverfahren abfragt und damit einen schnellen Überblick über mögliche Anwendungsgebiete bietet. Auch konnten so verstärkt Informationen zu In-vivo-Verfahren erfragt werden, deren Beurteilung sich aufgrund einer oftmals geringeren Datendichte und einer höheren Komplexität der Endpunkte als schwieriger erweist. Die Auswahl erfolgte nach dem Validierungs- 
Tabelle 2 Stärken und Schwächen von 5 In-vitro-Testverfahren (aus Leusch 2008)

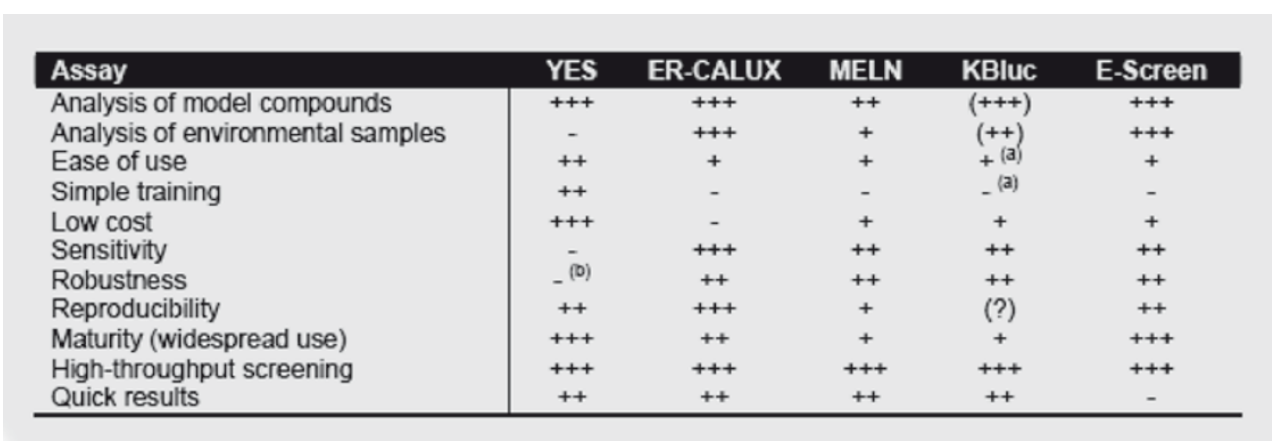

Legende: $-=$ unterdurchschnittlich; $+=$ mäßig, $++=$ gut,$+++=$ ausgezeichnet. (a) Der KBlueC lief nur in einem Labor. (b) Octylphenol verursachte ein Verschleppungsproblem auf der Mikrotiterplatte status und anhand von der durch Publikationen nachgewiesenen Umweltprobentauglichkeit mit entsprechender Sensitivität.

Aus 15 Testverfahren ( 5 in vivo und 10 in vitro) konnten 8 Verfahren der OECD erfasst werden, und 3 von 5 In-vitro-Verfahren aus dem GWRC-Report ,Tools to detect estrogenic activity in environmental waters" (Leusch 2008) wurden berücksichtigt. $\mathrm{Zu}$ einem Testverfahren wurde neben der Grundinformation eines Testverfahrens, die Sensitivität bzw. auch der Arbeitsbereich, die Anwendbarkeit, die Standardisierbarkeit/Verfügbarkeit, der Aufwand, die Kosten, die Praktikabilität und die biologische und ökotoxikologische Relevanz bei versierten Anwendern abgefragt. Es wurden nur Personen mit ausgewiesener Expertise für die Befragung gewählt, daher war entscheidend, ob diese schon eine Anzahl entsprechender Publikationen für diese Testverfahren vorzuweisen hatten oder eine aktive Mitwirkung in Gremien zur Biotestentwicklung (Validierung/Normung) bekannt war. Um die Subjektivität der Angaben zu reduzieren, wurde ein Verweis auf entsprechende Literaturquellen zur Stützung der Angaben oder kurze Begründungen gefordert, und es fand nach Eingang der Befragungsergebnisse eine Prüfung der Ergebnisse mit anderen Literaturangaben statt. Bei Fragen, Unklarheiten oder dem Verdacht auf Fehlinformation wurden durch Telefonate die kritischen Punkte erneut erörtert und es fand eine Anpassung oder ein Weglassen der Information statt. Da es sich um sensible Daten handelt, die sich im Rahmen von zukünftigen Projekten noch ein wenig revidieren können, wurde eine allgemeine Anonymisierung der Befragten bevorzugt. Trotz dieser Bemühungen um Objektivierung der Angaben und dem hohen Informationsgehalt, der zur Verfügung gestellt wurde, sind subjektive Einflüsse nicht gänzlich auszuschließen, da jedes Verfahren nur einmalig erfasst werden konnte. Diese Abfrage stellt daher eine Erweiterung zum verfügbaren Wissen durch eine Literaturrecherche dar und kann ebenfalls als Orientierungshilfe zur Identifikation geeigneter Testverfahren für verschiedene
Anwendungszwecke dienen. Einige vielversprechende Invitro- und In-vivo-Tests wurden aus folgenden Gründen nicht in die Abfrage mit einbezogen. Für Verfahren wie der T47D-K-BlueC (Wilson et al. 2004) und den OECD validierten TA-Assay (Takeyoshi 2006) wurden Anfragen gestartet, es erfolgte jedoch kein Rücklauf. Für In-vitroFischrezeptor-Tests konnte kein Anwender/Experte gefunden werden, der die Abfrage beantwortete, was darauf hinweist, dass diese Tests im Moment kaum verbreitet und in Anwendung sind. Ähnlich scheint es sich bei In-vitroVitellogenin-Induktionstests mit Fischhepatozyten zu sein. Beide fischbasierten In-vitro-Testarten könnten jedoch in Zukunft für ein Umweltmonitoring von Interesse sein (OECD 2009, in Vorbereitung).

In-vivo-Testverfahren, wie die in OECD-Validierung befindlichen Fish Short Term Reproduction Assay oder der Fish Sexual Development Test (siehe Tabelle 4) wurden aufgrund des enormen Arbeitsaufwandes und dem damit verbundenen Verlust an Praktikabilität für eine Untersuchung von Gewässern nicht für die Abfrage in Betracht gezogen. Folgende Testverfahren wurden durch die Abfrage erfasst (Tabelle 3).

\subsubsection{Ergebnisse der Kriterienabfrage der Testverfahren}

Zunächst wurden Fragen zur ökotoxikologischen Relevanz und Eignung des Testverfahrens gestellt (Abb. 4):

a) Ist das Testverfahren aus Ihrer Sicht als Screening-Verfahren geeignet, um in Umweltproben hormonaktive Potentiale anzuzeigen?

b) Für wie geeignet halten Sie den ermittelten Endpunkt, um hormonaktive Wirkungen in Gewässern für ein breites Organismenspektrum anzuzeigen?

c) Ist das Testverfahren aus Ihrer Sicht als Monitorverfahren geeignet, um bestimmte hormonaktive Wirkungen in Gewässern im Routineeinsatz anzuzeigen?

Die In-vivo-Verfahren wurden bis auf den XEMA im Allgemeinen als schlechtere Screening-Verfahren bewertet 
Tabelle 3 Bei Anwendern abgefragte Testverfahren und Endpunkte zur Erfassung hormonaktiver Wirkungen

Durch Kriterienprofile erfasste Testverfahren und deren Endpunkte zum Nachweis hormonaktiver und reproduktionstoxischer Wirkungen

\section{In vivo-Verfahren:}

1) FSA: Fish Screening Assay (erweitert) in OECD Validierung

Biomarker (Vitellogenin; zusätzlich möglich 11-keto Testosteron); Reproduktionsparameter (Eizahl, Befruchtungsrate), optional: Histologie

2) XEMA: Amphibienmetamorphoseassay mit Xenopus laevis (erweitert) ab 04/09 als OECD-Guideline verabschiedet

Endokrine Disruption des Schilddrüsensystems anhand von Entwicklungsstadien (morphologische Parameter), Schilddrüsenhistologie (Genexpression möglich)

3) Pa-Repro: Reproduktionstest mit Potamopyrgus antipodarum in OECD Prävalidierungsphase

Embryonenzahl in der Bruttasche, die unter Einfluss von östrogenen/androgenen und reproduktionstoxischen Substanzen moduliert wird.

4) Dm-Repro:Daphnienreproduktionstest, bereits OECD validiert (TG 211) aber ohne endokrine Spezifität, Erweiterung geplant

Überleben, Nachkommenzahl nach Guideline; Erweiterung für endokrine Effekte (vorgeschlagen): Geschlechtsverhältnis der Nachkommen

5) Chirotest:Chironomidentest, bereits OECD validiert (TG 218-219) aber ohne endokrine Spezifität, Erweiterung geplant

Schlupfrate (Emergenz) u. Entwicklungsrate, Ausweitung der Testlänge auf 45 Tage, inkl. Reproduktiver Phase, zusätzliche Endpunkte: Anzahl Eistränge, Fruchtbarkeit der Eistränge, Lebensfähigkeit der Nachkommen

\section{In vitro-Verfahren:}

6) MVLN-Test

Enzymaktivität nach hER abhängigen Reportergentranslation in transfizierten MCF-7-Zellen

7) YES nach McDonnell

Agonistische und antagonistische Rezeptorbindung am humanen ER $\alpha$ in rekombinant veränderten Hefezellen (BJ 3505)

8+9) YES/YAS nach Sumpter und nach Schultis/Metzger modifiziert

Agonistische und antagonistische Rezeptorbindung am humanen ER $\alpha$ und AR in rekombinanten Hefezellen mit Lyticase katalisiertem Endverdau der Zellen

10) H295R Steroidgenesis Assay, bereits OECD validiert und Bestandteil des EDSP

Disruption der Steroidgenese von 17-beta-Estradiol und Testosteron, Messung der Aromatasemodulation möglich

11+12) ER-Calux alpha, AR-Calux

luminometrische Messung einer humanen ER $\alpha$ und AR rezeptorvermittelten Antwort von T47 D rekombinant veränderten Brustkrebszellen

13) E-screen, MCF-7-Proliferationstest

Induktion der Zellproliferation von Mammakarzinomzellen humanen Ursprungs (MCF-7-Zellen)

14) Enzyme-Linked-Receptor-Assay, ELRA

Rezeptorbindungsassay, der agonistische und antagonistische Rezeptorbindung am humanen ER $\alpha$ erfasst

15) AWACCS Biosensor, der Multianalytbestimmungen ermöglicht

Multianalyt-Immunoassay für aquatische Schadstoffe

a

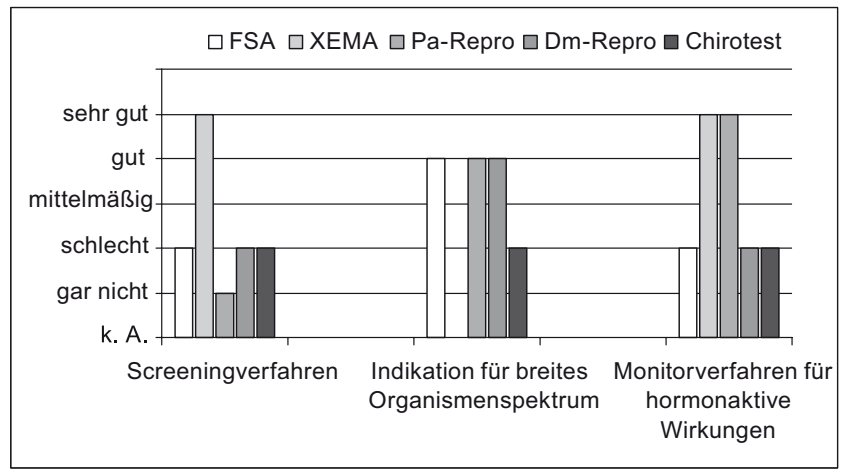

b

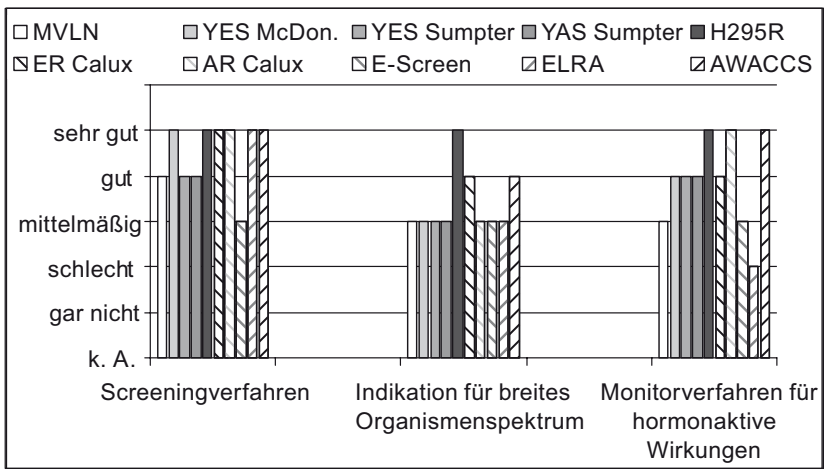

Abb. 4 Ökotoxikologische Einschätzung von Testverfahren für hormonaktive Wirkungen

als die meisten In-vitro-Verfahren. So wurde z. B. 4-mal angegeben, dass die In-vivo-Verfahren zu aufwändig seien, und 2-mal wurde eine eingeschränkte Übertragbarkeit der Ergebnisse angegeben. Eine Einschätzung der Eignung als Monitorverfahren fiel für die In-vivo-Verfahren unterschiedlich aus. Die Befragung zum Indikationswert des 
Endpunktes für ein breites Organismenspektrum wurde für die In-vitro-Verfahren mindestens als „,mittelmäßig“ eingeschätzt, die Angaben für die In-vivo-Verfahren variierten hingegen von „schlecht“ bis „gut“. Eine Einschätzung des XEMA wurde mit ,sehr gut" für Verteberaten angegeben. Da der Anteil der Vertebraten in aquatischen Systemen variieren kann, wurde die Angabe nicht gewertet. Der Chironomidentest wurde diesbezüglich als ,schlecht“ bewertet, da eine Übertragbarkeit auf Insekten beschränkt ist. Allerdings kann der Insektenanteil gewässerspezifisch relativ hoch liegen. Während In-vitro-Verfahren eher für Kurzzeitexpositionen geeignet sind, können In-vivo-Verfahren Langzeiteffekte erfassen.

\subsubsection{Erfassung des Zeitaufwandes der Testverfahren}

Die In-vivo-Verfahren benötigen je nach gemessenem Endpunkt oft einen wesentlich höheren Zeitaufwand als die $I n$ vitro-Verfahren (Abb. 5). Bei den In-vivo-Verfahren benötigt der Reproduktionstest mit Potamopyrgus antipodarum den längsten Gesamtzeitbedarf, gefolgt vom Fisch-ScreeningAssay. Bei den In-vitro-Verfahren benötigten erwartungsgemäß (siehe Tabelle 1) der E-Screen und der MVLN-Test den größten Zeitaufwand. Bei den YES/YAS-Verfahren wurde der zeitliche Aufwand der Übernachtkultur (Vorbereitungszeit) nicht berücksichtigt, damit verlängert sich der Gesamtzeitbedarf dieser Verfahren noch einmal um 16-18h. Parallel zum Zeitaufwand wurde auch der geschätzte Arbeitsaufwand befragt.

\subsubsection{Erfassung des Arbeitsaufwandes der Testverfahren}

Auch der Arbeitsaufwand lag für die In-vivo-Verfahren erheblich höher als für die In-vitro-Verfahren (Abb. 6). Jedoch zeigte sich, dass der Reproduktionstest mit Potamopyrgus antipodarum bei dem längsten Gesamtzeitbedarf mit dem geringsten Arbeitsaufwand angegeben wurde. Bei den Invitro-Verfahren wurde der MVLN-Test, der eine Weiterent- a

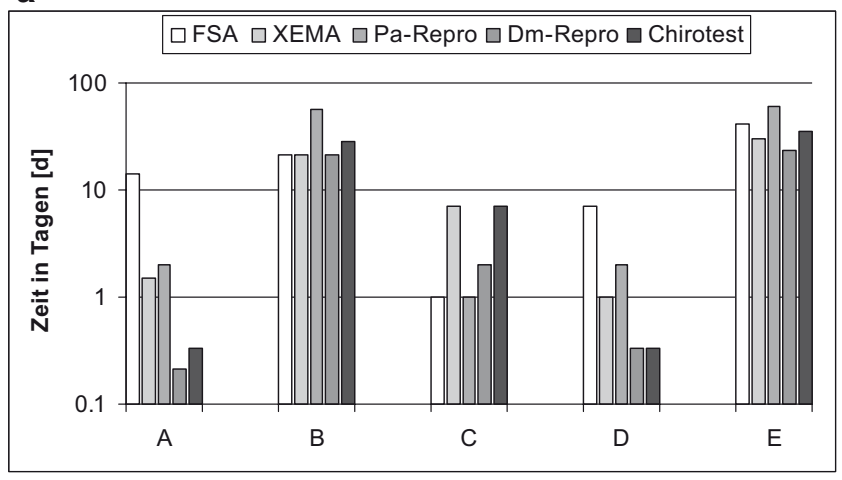

b

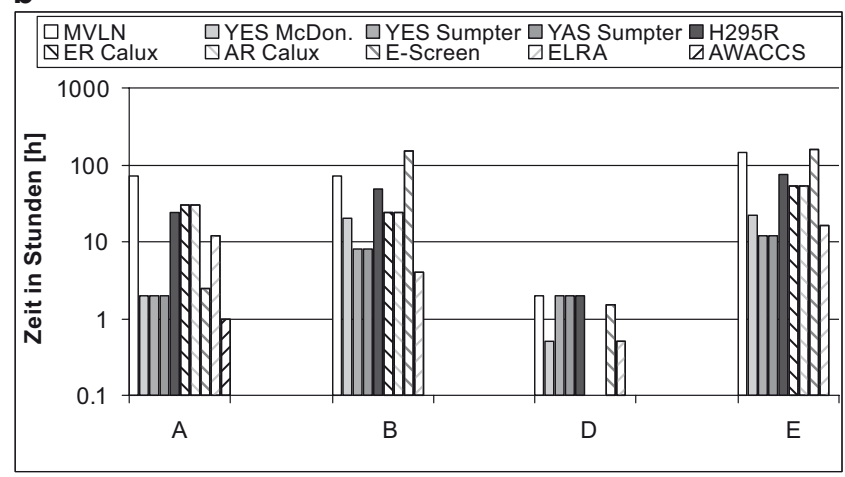

Abb. 5 Zeitaufwand von Testverfahren für hormonaktive und reproduktionstoxische Wirkungen; A=Vorbereitungszeit, $B=$ Versuchsdauer, $\mathrm{C}=$ Vortestungen, $\mathrm{D}=$ Auswertungszeit, $\mathrm{E}=$ Gesamtzeitbedarf. Der Zeitaufwand für Vortestungen bei den In-vitro-Tests wurde mit 0 angegeben und daher nicht dargestellt

a

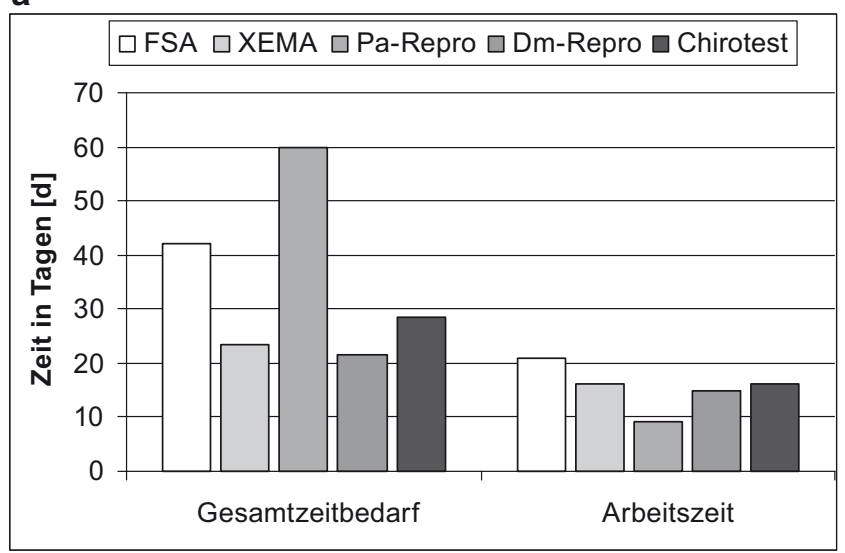

b

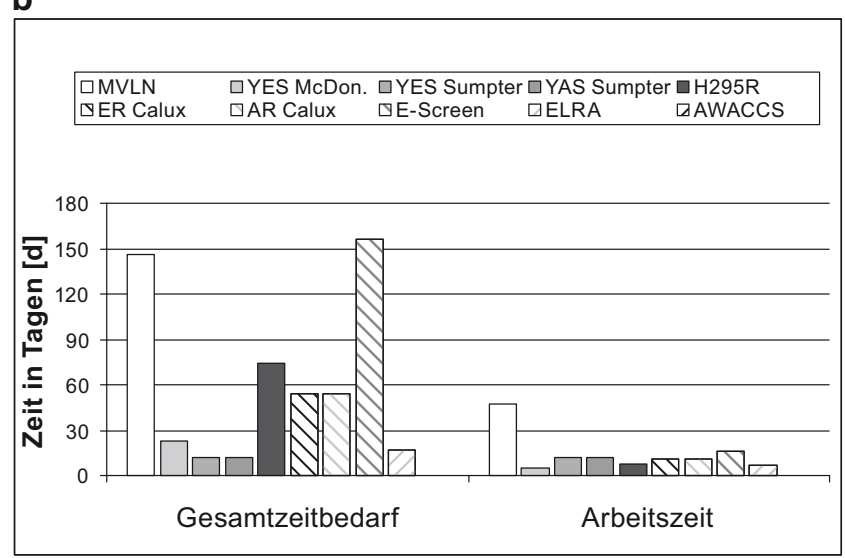

Abb. 6 Arbeitsaufwand von Testverfahren für hormonaktive und reproduktionstoxische Wirkungen 
wicklung des E-Screens ist, als wesentlich arbeitsintensiver ( $47 \mathrm{~h}$ im Vergleich zu 16h) beschrieben. Neben der Arbeitszeit wurden die Materialkosten für einen Versuchsansatz und die gesamten Installationskosten (Messgeräte, Versuchsapparatur, Testkomponenten) abgefragt, um den Versuch in einem nicht ausgestatteten Labor erstmalig zu installieren.

\subsubsection{Erfassung der Materialkosten von Testverfahren}

Die Materialkosten (Abb. 7) für In-vivo-Verfahren wurden im Mittel höher eingeschätzt als die der In-vitro-Verfahren. Der FSA(Fish-Screening Assay) und der XEMA belegten die höchsten Kostenklassen. Bei den In-vitro-Verfahren zeigte sich der MVLN-Test als sehr aufwändig. Der H295R Steroidgenesis Assay wurde bezüglich der Materialkosten gleichwertig mit dem Daphnienreproduktionstest eingeschätzt, der die geringste Kostenklasse bei den In-vivo-Verfahren belegte. Für den Chironomidentest lag keine Einschätzung vor. In einem Versuchsansatz mit In-vitro-Verfahren werden in der Regel mehr Substanzkonzentrationen bzw. Probenverdünnungen getestet als bei In-vivo-Verfahren (nicht gezeigte
Daten), was sich zusätzlich günstig auf den Kostenaufwand pro Probe auswirkt.

\subsubsection{Erfassung der Installationskosten von Testverfahren}

Für die Installationskosten (Abb. 8) zeigen die In-vitroVerfahren eine ähnliche Klassenverteilung wie die In-vivoVerfahren, was wahrscheinlich auf die relativ hohen Kosten bei der Anschaffung der Mikrotiterplattenlesegeräte für luminometrische und photometrische Messungen zurückzuführen ist. Erneut wurde der MVLN-Test als sehr kostenintensiv eingeschätzt.

\subsubsection{Erfassung der Sensitivitäten der Testverfahren}

Für 5 Testverfahren lagen aufgrund der Verwendung von anderen Standardsubstanzen keine Angaben zu den Sensitivitäten vor (Abb. 9). Bei den In-vitro-Verfahren kann folgende Sensitivitätsreihung für 17-beta-Estradiol anhand der $\mathrm{EC}_{50}$ vorgenommen werden: ER-Calux $<$ E-Screen $<$ MVLN $<$ YES Sumpter $<$ ELRA. Der

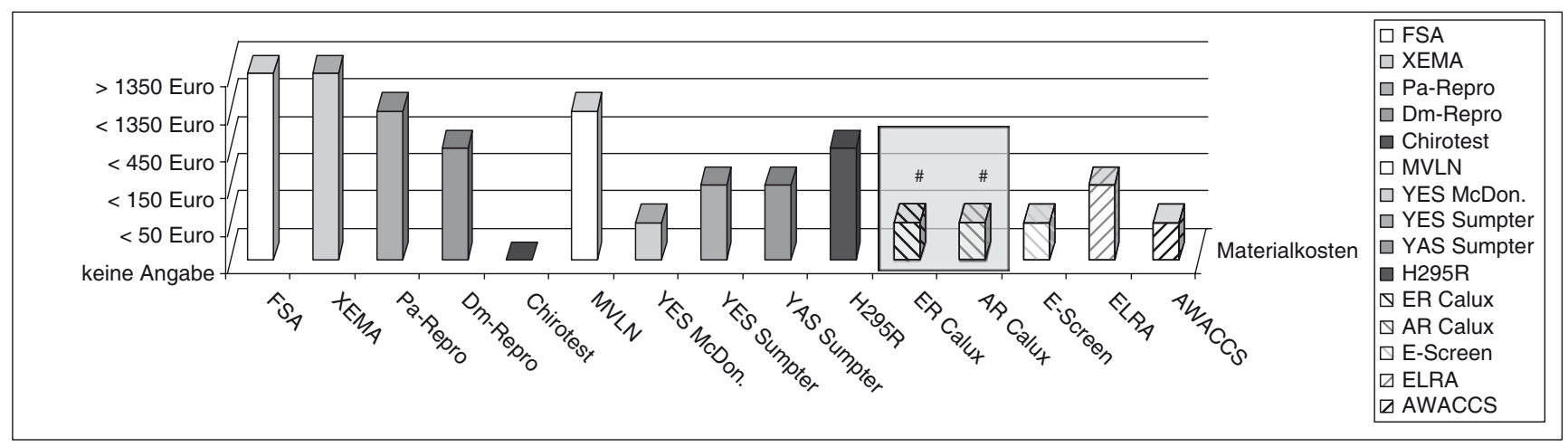

Abb. 7 Materialkosten von Testverfahren für hormonaktive und reproduktionstoxische Wirkungen für einen Versuchsansatz; kommerzielle Verfahren wurden mit einem \# gekennzeichnet, die anfallenden Kosten sind bei den Anbietern zu erfragen

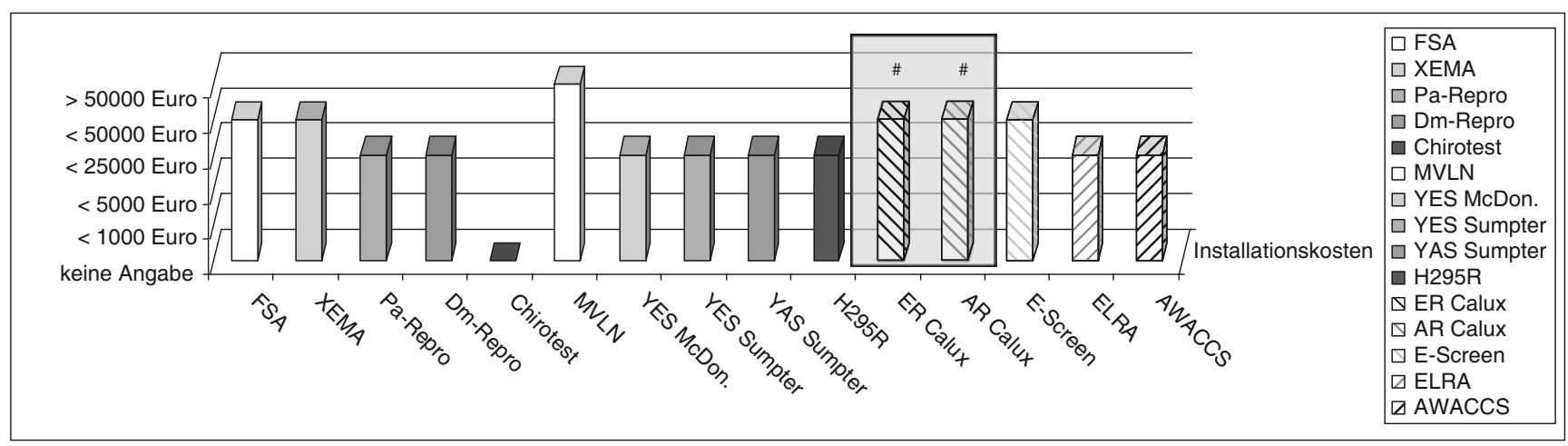

Abb. 8 Installationskosten (Messgeräte, Versuchsapparatur, Testkomponenten) von Testverfahren für hormonaktive und reproduktionstoxische Wirkungen, die bei einer Erstinstallation in einem Labor anfallen; kommerzielle Verfahren wurden mit einem \# gekennzeichnet, die anfallenden Kosten sind bei den Anbietern zu erfragen 


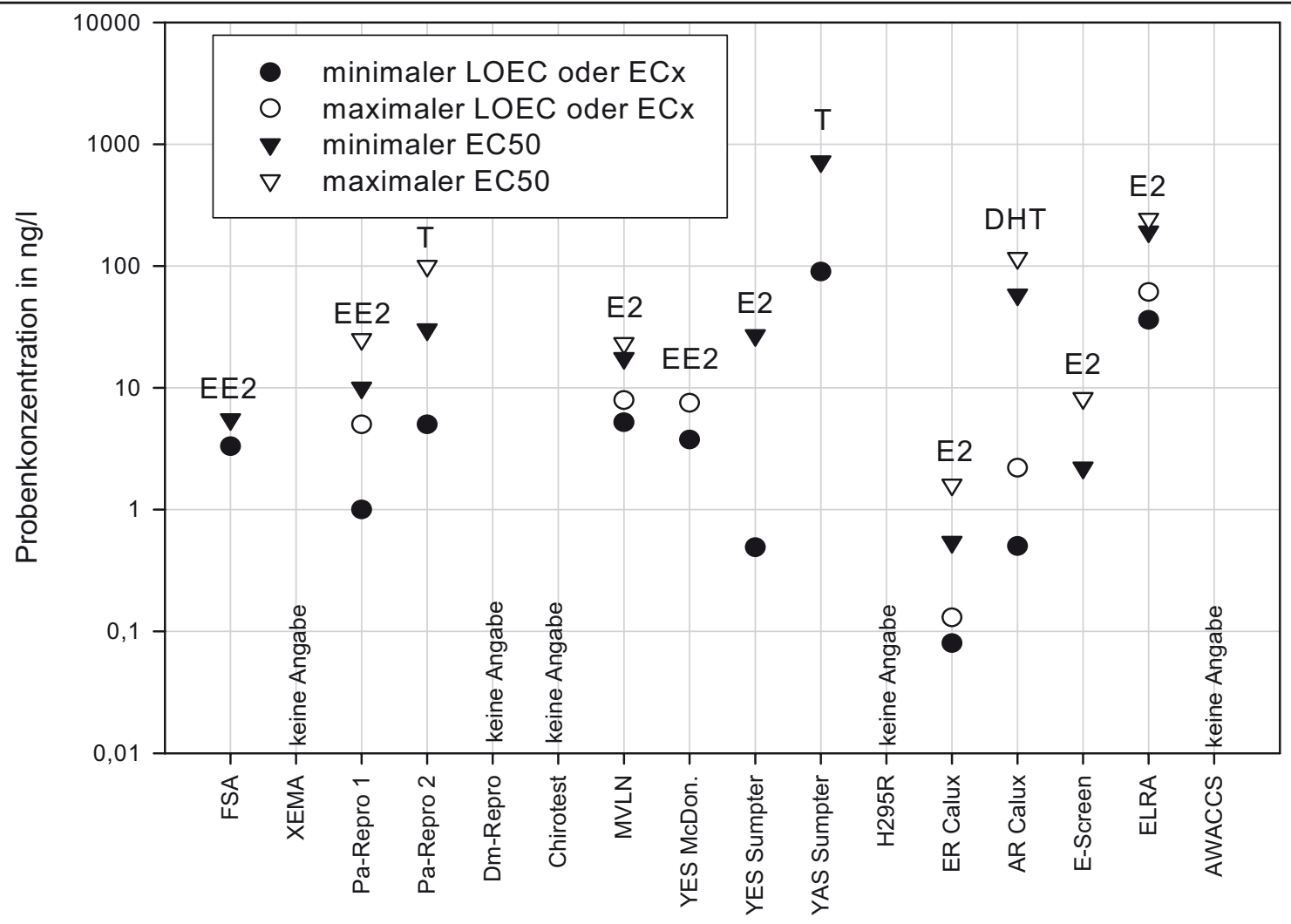

Abb. 9 Sensitivitätsvergleich von Testverfahren für hormonaktive Wirkungen aus der Abfrage. Minimale und maximale LOEC oder $\mathrm{EC}_{\mathrm{X}}$-Werte $(\mathrm{X}=10$ oder 20$)$ sowie $\mathrm{EC}_{50}$-Werte wurden für verschiedene Testsubstanzen dargestellt. $\mathrm{T}=$ Testosteron; $\mathrm{DHT}=\mathrm{Dihydrotestosteron;}$ $\mathrm{E} 2=17$-beta-Estradiol, EE2 =17-alpha-Ethinylestradiol

ER-Calux zeigt auch die geringsten LOEC-Werte und scheint für 17-beta-Estradiol eine hohe Sensitivität aufzuweisen. Aufgrund der Lückenhaftigkeit der Datenangaben und der Unterschiedlichkeit der verwendeten und auch verwendbaren Testsubstanzen lassen sich nur begrenzte Schlussfolgerungen ableiten. So kann z.B. der YAS nach Sumpter nicht mit dem AR-Calux verglichen werden, da unterschiedliche Substanzen getestet wurden (Sumpter 1995). Testverfahren wie der XEMA oder der H295R Steroidgenesis Assay arbeiten aufgrund ihrer Wirkmechanismen mit anderen Referenzsubstanzen. Sowohl In-vitro- als auch In-vivo-Verfahren ermöglichen den Nachweis östrogener Substanzen im unteren ng/l-Bereich.

\subsubsection{Erfassung der Anwendungsbereiche der Testverfahren}

Der FSA und der Chironomidentest wurden in ihrer Anwendbarkeit sehr eingeschränkt dargestellt, wo hingegegen die anderen Verfahren als sehr flexibel für verschiedene Anwendungsbereiche bewertet wurden (Abb. 10). Leider konnten nur die Anwendungsbereiche für die In-vivo-Verfahren vergleichend dargestellt werden. Einige In-vitro-
Verfahren (z. B. die ER- und AR-Calux-Systeme, bestimmte YES-Verfahren oder der H295R Steroidgenesis Assay) testen Oberflächenwasser oder Abwasserproben erst nach Extraktionen. Dies kann erstens auf Überlagerungen mit möglichen zytotoxischen Effekten zurückzuführen sein oder darauf, dass mit Extraktionen oftmals auch Aufkonzentrierungen verbunden sind, die z. B. eine zu starke Verdünnung von Wachstumsmedien durch die Probe umgehen. Ebenfalls sind für wirkungsbezogene Analyseansätze Extraktionen absolut notwendig. Andere Verfahren wie der ELRA oder

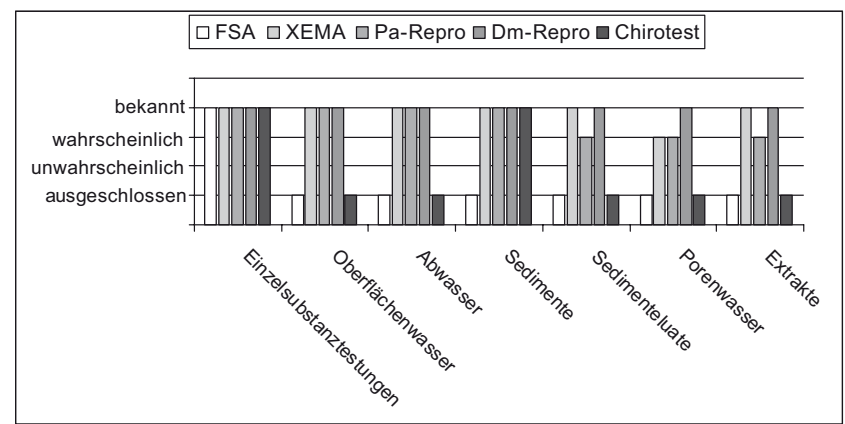

Abb. 10 Anwendungsbereiche der In-vivo-Verfahren 
die modifizierten Sumpter-YES/YAS-Systeme können mit nativen Wasserproben arbeiten und sind ausreichend sensitiv und robust um bestimmte Umweltprobenbewertungen durchzuführen. Eine Ringtestung mit nativen oder dotierten Proben unterschiedlicher Belastungsqualität könnte wertvolle Informationen zu den möglichen Anwendungsbereichen liefern.

\subsubsection{Bewertung der Standardisierbarkeit, Verfügbarkeit und Verbreitung von Testverfahren}

Den Anwendern und Entwicklern wurden folgende Fragen zur Standardisierbarkeit und Verfügbarkeit gestellt (Abb. 11):

a) Wie gut schätzen Sie die Standardisierbarkeit ein?

b) Wie gut sind Testkomponenten und/oder Testorganismen in gleichbleibender Qualität über das gesamte Jahr kommerziell erhältlich?

c) In wie vielen Laboren wissen oder vermuten Sie, dass derzeit das Testverfahren angewendet wird?

Die Standardisierbarkeit der In-vitro- und In-vivo-Verfahren wurde relativ hoch eingeschätzt. Nur der E-Screen und der FSA wurden als mittelmäßig zu standardisieren bewertet. Da sämtliche dargestellten In-vivo-Verfahren sich in Normungen oder Prävalidierungen für die OECD befinden oder bereits genormt sind, war dieses Ergebnis zu erwarten. Die Verfügbarkeit der Systemkomponenten wurde ebenfalls relativ hoch eingeschätzt. Eine mittelmäßige Bewertung erhielt der Reproduktionstest mit Potamopyrgus antipodarum. Für diesen Test wurden auch reproduktionszyklische Schwankungen eingeräumt, zu denen die Testung östrogener (Frühjahr) und androgener Substanzen (Spätsommer und Herbst) aufgrund der dann natürlicherweise hohen bzw. niedrigen Embryonenzahl nur eingeschränkt möglich ist (Gefahr falsch negativer Befunde). Eine Gefahr von falsch negativen und falsch positiven Befunden wurde auch für die anderen Testverfahren abgefragt (nicht gezeigte Daten),

a

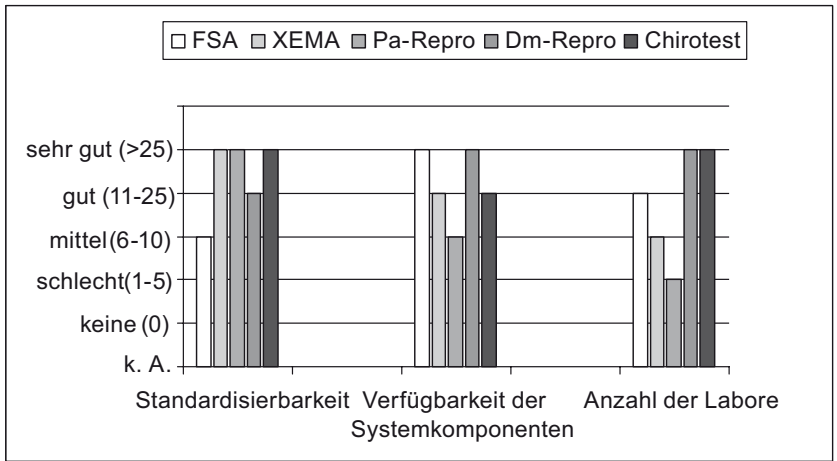

führte aber zu Verwirrungen in der Beantwortung, da der Ausgangspunkt für eine solche Aussage zuvor nicht geklärt wurde. Diese Angabe ist auch von den betrachteten Wirkmechanismen abhängig und wird in der Diskussion aufgegriffen. Eine Einschätzung der Verbreitung der Testverfahren konnte gut mit den Angaben in den Literaturquellen in Zusammenhang gebracht werden. Je nach Bekanntheitsgrad und Validierungszustand der Testverfahren wurde auch die geschätzte Anwendungshäufigkeit angegegeben. Testverfahren wie der Daphnienreproduktionstest oder der Chironomidentest, die bereits OECD-validiert sind und z.B. zur Pflanzenschutzmittelbewertung benutzt werden, sind gegenüber in der OECD-Validierung befindlichen Verfahren weiter verbreitet. Beide Verfahren werden derzeit gezielt für die Untersuchung von hormonaktiven Substanzen erweitert (siehe Tabelle 3). Ältere Verfahren wie der E-Screen besitzen aufgrund ihrer Bekanntheit eine häufigere Anwendung als neuere Verfahren. Die starke Verbreitung der YES/YASSysteme (siehe Tabelle 1) konnte auch in dieser Abfrage gezeigt werden. Der Schwerpunkt liegt auf den Sumpter/Routledge-Varianten, was nicht differenziert aufgeführt wurde. Eine tabellarische Zusammenfassung der Gesamtergebnisse der Kriterienprofile befindet sich in Tabelle 5.

Die Validierung und Normung (Standardisierung) von Testverfahren sind wichtige Werkzeuge, um die methodischen Grenzen und die Anwendbarkeit von Testverfahren zu beschreiben. Auch wenn der Zeitaufwand für diese Prozesse beachtlich sein kann, so wird eine Erhöhung der Akzeptanz und Verbreitung erreicht und bietet die Möglichkeit Testverfahren in regulative Bewertungsverfahren zu implementieren. Daher werden diese Aspekte im nachfolgenden Abschnitt behandelt.

\subsubsection{Rolle der Validierung und Normung für Testverfahren}

Der Sinn von Normen besteht darin eine Vergleichbarkeitsbasis oder einen Maßstab zur Bewertung einer Vergleichbar-

b

\begin{tabular}{cccc|}
\hline $\begin{array}{c}\square \mathrm{MVLN} \\
\square \mathrm{H} 295 \mathrm{R}\end{array}$ & $\square \mathrm{YES}$ McDon. & $\square \mathrm{YES}$ Sumpter & $\square \mathrm{YAS}$ Sumpter \\
$\square \mathrm{ELRA}$ & $\square \mathrm{EWACCS}$ & $\square \mathrm{AR}$ Calux & $\square \mathrm{E}$-Screen \\
sehr gut (>25) \\
gut (11-25) \\
mittel (6-10) \\
schlecht (1-5) \\
keine (0) \\
k. A.
\end{tabular}

Abb. 11 Standardisierbarkeit, Verfügbarkeit und Verbreitung von Testverfahren für hormonaktive und reproduktionstoxische Wirkungen. Die Zahlen stehen für die geschätzte Anzahl der Labore, in denen das Testverfahren angewendet wird 
keit bereitzustellen. Angaben zu einer statistischen Aussagesicherheit, der Standardisierbarkeit, Automatisierbarkeit und Reproduzierbarkeit von Testverfahren lassen sich oft nur in aufwändigen Ringversuchen mit mehreren Laboratorien genauer treffen. Es ist auch nicht immer möglich eine einheitliche Standard Operating Procedure (SOP) bei der Untersuchung gleicher Proben in unterschiedlichen Laboratorien zu verwenden, da die apparative Ausstattung sehr variieren kann. Größere Ringversuche ( $>6-7$ Laboratorien) können helfen, die kritischen Anwendungsschritte in SOPs zu identifizieren (Leusch 2008). Methodische Schwachpunkte können über einen Validierungsprozess genauer identifiziert werden. Die OECD beschäftigt sich mit Chemikalienprüfung, ISO und CEN mit der Prüfung von Umweltproben, wobei valide Tests für Chemikalienprüfungen auch für Umweltprüfungen interessant sein können. Neben einem Erkenntnisgewinn über die Anwendbarkeit und Leistungsfähigkeit eines Testverfahrens können im Verlauf der Normierung von Testverfahren vielfältige Vorteile erzielt werden (verändert nach Pluta 2008b):

- Sicherheit, dass die Methoden auf andere Laboratorien übertragbar und valide sind

- Aufmerksamkeit aller interessierten Gruppen für das Testverfahren, unabhängig von einer wirtschaftlichen Leistungsfähigkeit und sprachlichen Fähigkeiten

- nationaler Transfer internationaler Standards

- Vermeidung redundanter Arbeit und unnötiger Konkurrenzentwicklung

- die Ergebnisse, die mit diesem OECD-validierten Test erlangt werden, müssen von allen Mitgliedsstaaten akzeptiert werden

- Möglichkeit der Berücksichtigung bei der Festlegung von Gesetzen

- Interessensausrichtung mehrerer unabhängiger Gruppen auf ein gemeinsames Ziel

- standardisierte und für den Verwendungszweck akzeptierte Methoden

- vergleichbare und gerichtsfeste Ergebnisse, die weltweit erhoben und bewertet werden können, womit auch internationale Vergleiche möglich sind

- standardisierte und validierte Methoden, auch als Werkzeug der Qualitätssicherung und der formalen Akkreditierung

- Nutzung vorhandener Netzwerke als Plattformen für wissenschaftliche Diskussionen und zur Ermittlung weiteren Entwicklungsbedarfs

- Möglichkeit prä- und co-normative Forschung anzustoßen, z. B. über drittmittelgeförderte Forschungsprojekte

Allerdings werden personelle und materielle Kapazitäten über einen längeren Zeitraum gebunden, wobei ein Teil der Aktualität der Untersuchungsinteressen verloren gehen kann. Besteht jedoch eine funktionierende Arbeitsvorschrift, so kann eine ISO oder CEN-Normung innerhalb von
2-3 Jahren erreicht werden. OECD-Validierungen können bei entsprechender Eignung durch Me-Too-Validierungen abgekürzt werden. Das Sortiment älterer genormter Methoden wächst, womit die Möglichkeit einer Verdrängung innovativer und moderner Testverfahren besteht. Ist ein Testverfahren einmal genormt, so ist es unabhängig von seiner Aussagekraft besser verfügbar als ein nicht genormtes Testverfahren.

Auch die Akzeptanz von validierten und normierten Testverfahren kann unterschiedlich ausfallen, OECD-Guidelines können sogar bei der Wahl der verwendeten Organismen Ermessensspielraum lassen, wohingegen DIN und ISONormen weitgehend festgelegter in den Methoden sind. Ein aktueller Vergleich der ISO- und OECD-Methoden befindet sich in OECD (2008b). Validitäts- und Gültigkeitskriterien, die Messunsicherheit, sowie die Beschreibung von Störungen und die Festlegung von Anwendungsbereichen sind elementare und obligatorische Bestandteile der Normung. Daher sollten Verfahren, die eine Umweltbewertung ermöglichen, einen Normungsprozess durchlaufen, um eine sichere und übertragbare Aussage treffen zu können. Tabelle 4 soll einen Eindruck vermitteln, wie vielfältig und unterschiedlich die zu erfassenden Endpunkte für die Identifikation hormonaktiver und reproduktionstoxischer Wirkungen sein können.

\section{Diskussion}

4.1 Kriterien einer Testauswahl aus ökotoxikologischer und regulativer Sicht

Die unterschiedliche Handhabung von Begrifflichkeiten bei der Identifizierung und Auswahl geeigneter Kriterien für Testverfahren führt oft $\mathrm{zu}$ Verständnisproblemen und erschwert eine Findung gemeinsamer inhaltlicher Schnittmengen, die, wie die folgenden Beispiele zeigen, durchaus vorhanden sind.

Beispiel 1 Eignungskriterien für Testverfahren in der Ökotoxikologie:

- Relevanz (besitzt einen Bezug und Bedeutung für das Ökosystem)

- Konstanz (hinreichende Wiederholbarkeit zu bestimmten Zeiten des Jahres)

- Empfindlichkeit (Effekte treten in umweltrelevanten Konzentrationen auf)

- Objektivierbarkeit (Mess- und Dokumentierbarkeit)

- Interpretierbarkeit (Rückschlüsse auf reale Freiland-Systeme möglich)

- Realisierbarkeit (vertretbarer zeitlicher, personeller, apparativer Aufwand)

- Standardisierbarkeit (definierte nachvollziehbare Versuchsbedingungen, die übertragbar sind) 


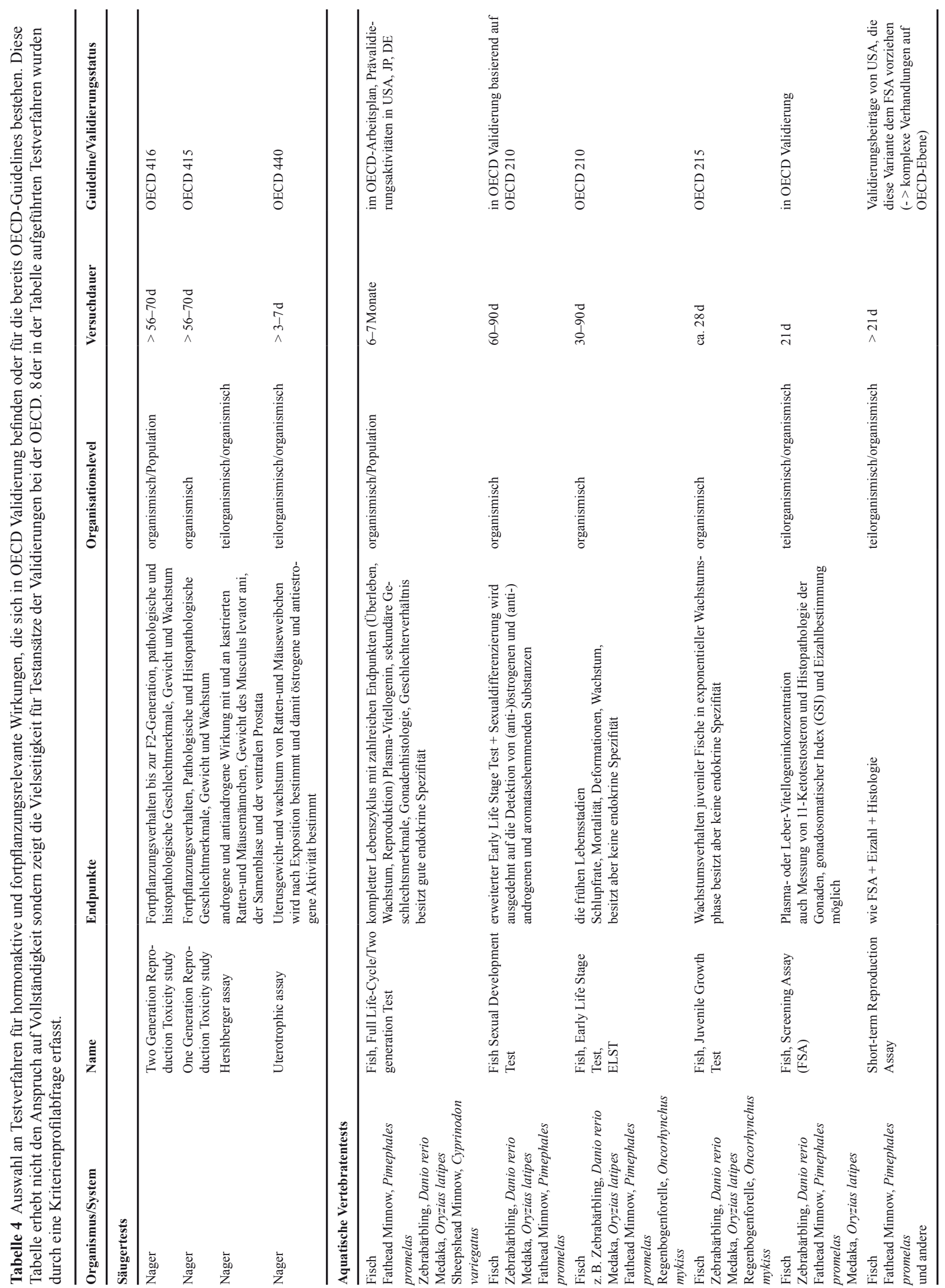




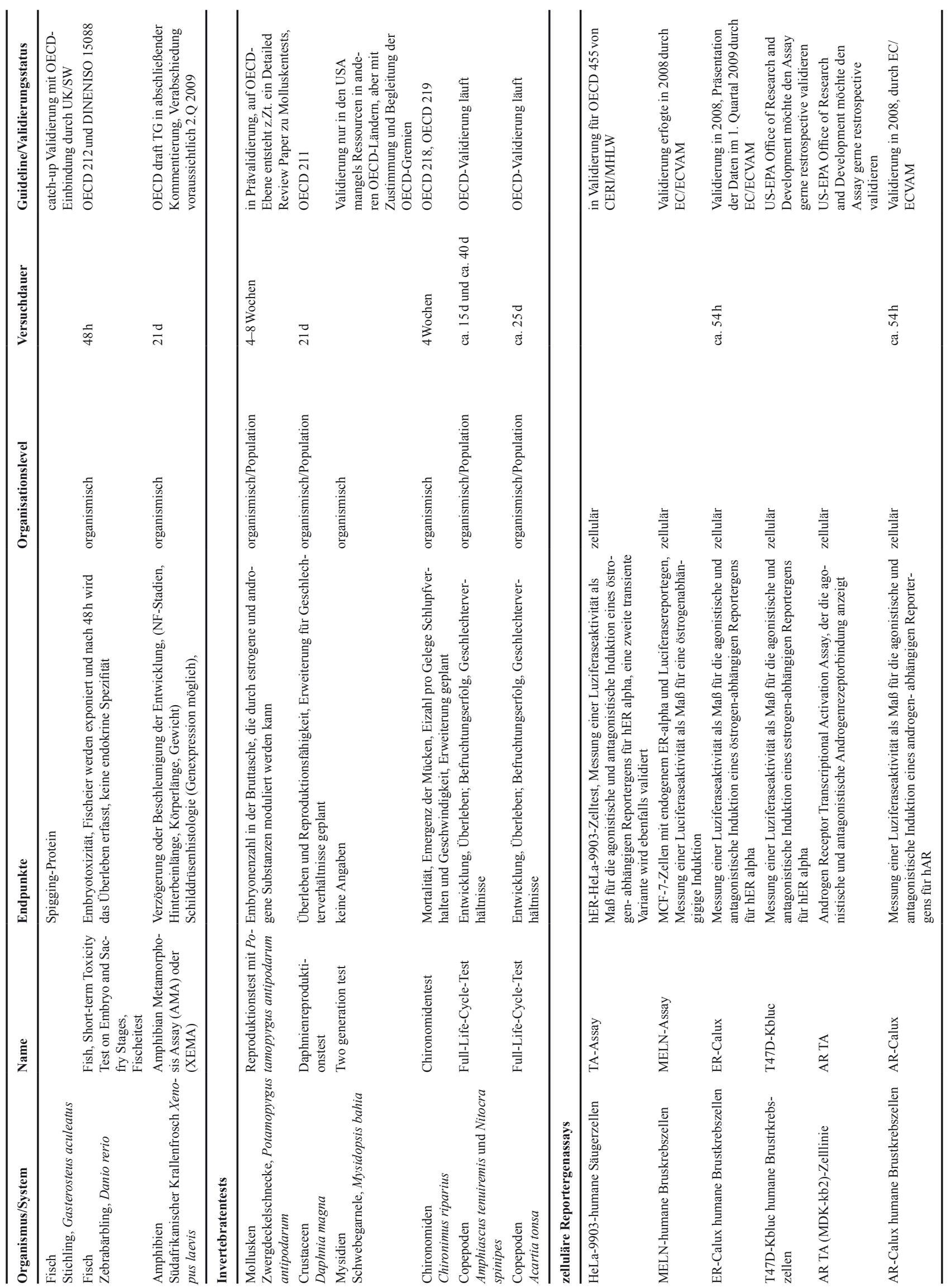




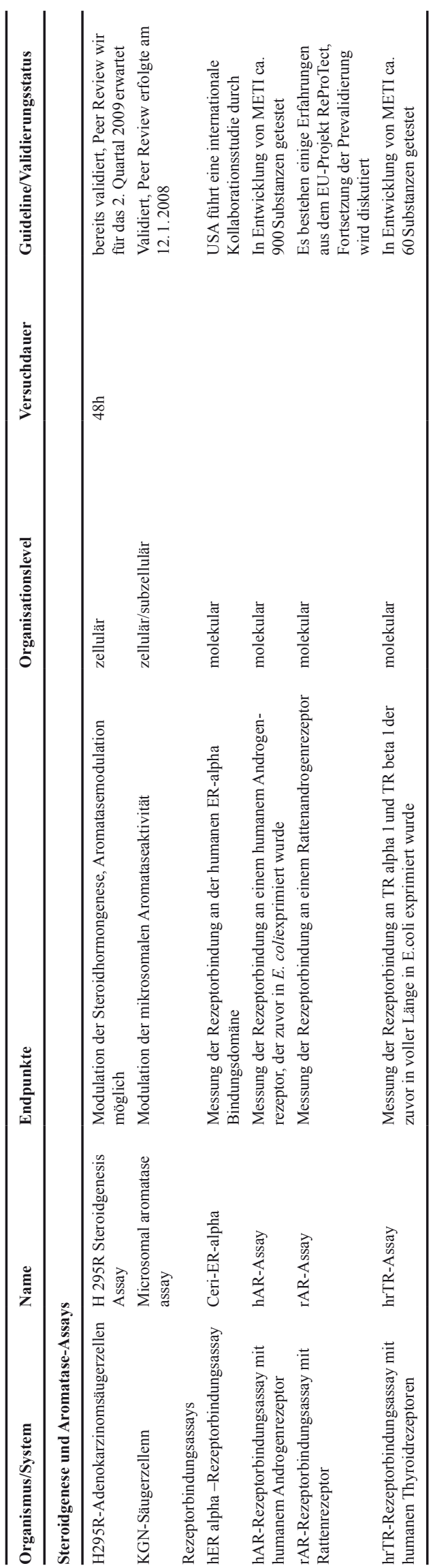

Beispiel 2 Anforderungen an biologische und chemischphysikalische Analysenverfahren als Überwachungsverfahren in der Abwasserverordnung (AbwV) zu § 7a WHG (Wasserhaushaltsgesetz) und Abwasser-Abgabengesetzes (AbwAG) (Pluta 2008a):

- Operationalität (Anzeige des Zieles der Abwasserbehandlungsmaßnahme direkt und sinnfällig über das Testergebnis)

- Reproduzierbarkeit (Standardisierte Testverfahren)

- Gerichtsfestigkeit (Festlegungen zur Durchführung des Verfahrens und zur Probenahme führen zu gerichtsfesten Ergebnissen)

- Rechtssicherheit (intrinsische Qualitätssicherung, Angaben zur Messunsicherheit)

- Sinnfälligkeit (Stellvertreterfunktion der Organismen oder eindeutige Wirkungserfassung)

- Optimale Testbedingungen ( $\mathrm{pH}$, Medien, Kulturbedingungen, Praktikabilität, Wirtschaftlichkeit)

- Kompatibilität mit EU-Recht, AbwV und AbwAG

Die Synthese von regulativen und ökotoxikologischen Sichtweisen ermöglicht die Entwicklung geeigneter Instrumente zur Umweltüberwachung, die eine belastbare Aussagekraft und eine hohe ökotoxikologische Relevanz besitzen können. Die größte Schnittmenge bieten ökotoxikologisch relevante Verfahren, die sich methodisch soweit in Validierungsprozessen bewährt haben, dass die von ihnen abgeleiteten Aussagen zuverlässig sind. Dennoch sollten auch innovative Verfahren berücksichtigt werden, von denen anzunehmen ist, dass sie sich zukünftig in Validierungen und Standardisierungen behaupten können und die eine ökotoxikologische Aussagekraft bzw. zumindest eine Indikatorfunktion besitzen. Konzeptuelle Überlegungen zum Besorgnisvorbehalt, dem Vorsorgegedanken und dem Verursacherprinzip sollten einbezogen werden (Pluta 2008a).

Es ist recht unwahrscheinlich, dass ein Testverfahren alle Aspekte gleichermaßen gut bedienen kann. In einem wichtigen Diskussionsbeitrag von Vertretern der Industrie (Länge et al. 2006) zu einer Bewertung und Validität von toxikologischen und ökotoxikologischen Studien für regulatorische Fragestellungen wurden Hauptkriterien definiert, die dabei zu erfüllen sind. Als Hauptkriterien wurden Nachvollziehbarkeit, Plausibilität, Relevanz und Reproduzierbarkeit der Studien angeführt. Eine „Nachvollziehbarkeit“ sollte erreicht werden, indem Relevanz und Fragestellung der Untersuchung klar definiert sind. Dennoch ergibt sich daraus die Problematik regulatorische Aspekte ausreichend flexibel und gleichzeitig gerichtsfest zu gestalten, damit eine Anwendbarkeit auch bei sich ändernden wissenschaftlichen und experimentellen Ausgangssituationen erhalten bleibt. Die „Reproduzierbarkeit“ als Wiederholungsgenauigkeit von Prüfergebnissen, kann nur bei entsprechender Einhaltung definierter bzw. standardisierter Versuchsbe- 
dingungen erreicht werden, womit große Anforderungen an In-vivo-Ansätze gestellt werden, da diese stärker einer biologischen Variabilität unterliegen. Im Rahmen von Validierungs- und Standardisierungsprozessen wird auch die Reproduzierbarkeit untersucht. Dieser Punkt findet sich inhaltlich in allen Ansätzen wieder. Die „Relevanz“ bezieht sich hier auf die Frage, inwieweit der experimentelle Ansatz für die Prüfung geeignet ist. Dabei sind die unterschiedlichen Anwendungs- und Arbeitsbereiche der Testverfahren, aber auch eine ausreichende Spezifität in der Aussagemöglichkeit zu berücksichtigen. Auch dieser Punkt wird im regulatorischen Ansatz unter der Sinnfälligkeit berücksichtigt und trifft für die ökotoxikologische Betrachtung zu. So konnte belegt werden, dass einige experimentelle Ansätze gar keine direkte Zuordnung für endokrine Aktivität zulassen, da einfachere Wirkmechanismen zuvor nicht ausgeschlossen wurden, z. B. durch Eiersterblichkeit oder Fraßhemmung der Testorganismen durch Chemikalieneinfluss (Barata et al. 2004). Sowohl mit In-vitro-, als auch mit In-vivo-Ansätzen sollte es möglich sein allgemeintoxische Effekte von spezifischen Endpunkten zu unterscheiden, um zuverlässige Aussagen treffen zu können. Unter „Plausibilität" ist eine Überprüfung zu verstehen, ob die Ergebnisse in sich konsistent sind und ob sie mit denen anderer valider Studien im Einklang stehen (Länge et al. 2006). Es wird deutlich, dass es ungemein schwierig ist einen allgemeinen Konsens in wissenschaftlichen, regulatorischen und industriellen Ansprüchen zu finden, zumal bei allen theoretischen Übereinstimmungen die Praktikabilität unter wirtschaftlichen und wissenschaftlichen Gesichtspunkten nicht verloren gehen darf.

\subsection{Einbeziehung der Abfrageergebnisse}

Eine eigentliche Bewertung der Anwendbarkeit der Testverfahren ist an praktische Erfahrungen und im besten Fall an Inter-Labor-Vergleiche gekoppelt. Wie bereits erwähnt kann die Qualität und Eignung eines Testverfahrens nicht oder nur selten anhand einer Literaturrecherche abgeleitet werden. Aus diesem Grund wurde eine Abfrage ausgewählter Kriterien von unterschiedlichen Testverfahren (Tabelle 5) bei versierten Anwendern und Entwicklern vorgenommen und ausgewertet. Diese soll als Orientierung für eine Entscheidungsfindung bei einer Wahl geeigneter Testverfahren dienen. Eine Auswahl von Ergebnissen der Umfrage kann hier dargestellt werden und ermöglicht einen Vergleich und eine Bewertung von insgesamt 15 Testverfahren (5 In-vivoVerfahren und 10 In-vitro-Verfahren) für jeweils 7 Bewertungskategorien. Acht Verfahren der OECD konnten erfasst werden und 3 von 5 In-vitro-Verfahren aus dem GWRCReport „Tools to detect estrogenic activity in environmental waters" (Leusch 2008) wurden berücksichtigt.

Die Klasseneinteilung zum Arbeitsaufwand und Zeitbedarf erfolgte nach einer Rangfolge. Die 3 Verfahren mit dem größten Zeitbedarf erhielten Rang 1, die Verfahren mit dem viert- bis sechstgrößten Zeitbedarf Rang 2 usw. Die Kriterien der Anwendbarkeit und Sensitivität der Testverfahren konnten hier nicht dargestellt werden. Genauere Informationen befinden sich im Ergebnisteil (siehe Abb. 4-11).

Hierbei handelt es sich um eine Darstellung von Erfahrungswerten einzelner Anwender und Entwickler mit einem Testverfahren, die natürlich subjektiv beeinflusst sind. Ge-

Tabelle 5 Ergebnisse der Kriterienabfrage für Testverfahren zur Erfassung hormonaktiver und reproduktionstoxischer Wirkungen

\begin{tabular}{|c|c|c|c|c|c|c|c|c|c|c|c|c|c|c|c|}
\hline & 左 & 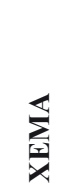 & $\frac{0}{\stackrel{0}{0}}$ & 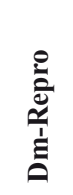 & 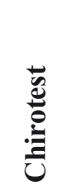 & $\frac{Z}{3}$ & 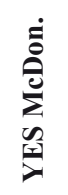 & 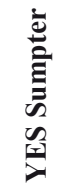 & 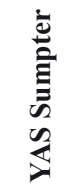 & $\begin{array}{l}\text { ̌ㅡ } \\
\text { בิ }\end{array}$ & 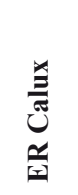 & 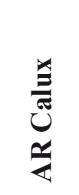 & 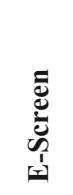 & 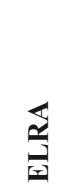 & $\sum_{\substack{k \\
k}}^{\infty}$ \\
\hline Eignung als Screeningverfahren & 2 & 5 & 1 & 2 & 2 & 4 & 5 & 4 & 4 & 5 & 5 & 5 & 3 & 5 & 5 \\
\hline Indikation für breites Organismenspektrum & 4 & - & 4 & 4 & 2 & 3 & 3 & 3 & 3 & 5 & 4 & 3 & 3 & 3 & 4 \\
\hline Eignung als Monitorverfahren & 2 & 5 & 5 & 2 & 2 & 3 & 4 & 4 & 4 & 5 & 4 & 5 & 3 & 2 & 5 \\
\hline geringer Gesamtzeitbedarf & 1 & 2 & 1 & 2 & 1 & 3 & 4 & 5 & 5 & 3 & 3 & 3 & 2 & 4 & 5 \\
\hline geringer Arbeitsaufwand & 1 & 1 & 2 & 2 & 1 & 2 & 5 & 3 & 3 & 4 & 4 & 4 & 3 & 5 & 5 \\
\hline geringe Materialkosten & 1 & 1 & 2 & 3 & - & 2 & 5 & 4 & 4 & 3 & 5 & 5 & 5 & 4 & 5 \\
\hline geringe Installationskosten & 2 & 2 & 3 & 3 & - & 1 & 1 & 3 & 3 & 3 & 2 & 2 & 2 & 3 & 3 \\
\hline Normungsstand $(5=\mathrm{ja} ; 3=$ in Normung, $1=$ nein $)$ & 3 & 3 & 3 & 5 & 5 & 1 & 1 & 1 & 1 & 3 & (3) & (3) & 1 & 1 & 1 \\
\hline Standardisierbarkeit & 3 & 5 & 5 & 4 & 5 & 4 & 5 & 5 & 5 & 5 & 5 & 5 & 3 & 5 & 5 \\
\hline Verfügbarkeit der Systemkomponenten & 5 & 4 & 3 & 5 & 4 & 4 & 4 & 4 & 4 & 5 & 5 & 5 & 4 & 5 & 5 \\
\hline Verbreitung des Testverfahrens & 4 & 3 & 2 & 5 & 5 & 3 & 5 & 5 & 5 & 4 & 4 & 3 & 5 & 2 & 2 \\
\hline mittlere Klasse: & 2,55 & 3,10 & 2,82 & 3,36 & 3,00 & 2,73 & 3,82 & 3,73 & 3,73 & 4,09 & 4,00 & 3,91 & 3,09 & 3,55 & 4,09 \\
\hline
\end{tabular}

Bewertungschlüssel: -= keine Angabe; $1=$,gar nicht/trifft überhaupt nicht zu“; 2 =,,schlecht/trifft nur bedingt zu“; $3=$ „,mittelmäßig/trifft zu“ $4=$,gut/trifft im hohem Umfang zu“; $5=$,,sehr gut/absolut erfüllt"“ 
wisse Trends oder herausragende Stärken und Schwächen können jedoch aus dieser Tabelle abgeleitet werden. So fallen z.B. der E-Screen und der MVLN-Test durch relativ hohe Versuchszeiten und einen großen Arbeitsaufwand für die In-vitro-Verfahren auf. Im Mittelwert sind In-vivoVerfahren schlechter als Screening-Verfahren bewertet und wiesen einen höheren Zeit- und Arbeitsbedarf sowie höhere Materialkosten auf. Die Einschätzung des XEMA als sehr gutes Screening- und Monitor-Verfahren wirft Fragen auf, da es sich um ein recht zeit-, arbeits- und kostenintensives Verfahren handelt (siehe Abb. 5, 6 und Tabelle 5). Der durch die Abfrage erfasste AWACCS-Biosensor ermöglicht Multianalytbestimmungen für eine Auswahl von Umweltchemikalien im unteren ng/l-Bereich und ist nicht für eine integrative Wirkungserfassung geeignet. Kein Testverfahren aus der Literaturrecherche und der Kriterienabfrage kann alle relevanten Wirkmechanismen zuverlässig, ausreichend sensitiv und praktikabel abbilden. Deshalb ist eine Kombination verschiedener Testverfahren zu empfehlen, bei der ihre unterschiedlichen Stärken eingebracht werden können. In eine ökotoxikologische Abwägung der Relevanz und der Sinnfälligkeit eines Testverfahrens sollte auch eine Berücksichtigung der Stellvertreterfunktion des gewählten Endpunktes eingehen.

\subsection{Problematik und mögliche Lösungsansätze}

Eine mögliche Vorgehensweise ist die Identifizierung von Testverfahren, die eine zuverlässige indikative Wirkung haben, z. B. In-vitro-Systeme. Diesen können dann valide In-vivo-Testverfahren nach- oder parallelgeschaltet werden, die populationsrelevante Aussagen zulassen. Für dieses Vorgehen sind zuvor Fragen zum Indikationswert von Testverfahren zu klären (verändert nach Schäfers 2007):

- Gibt es Endpunkte mit spezifischem Indikationswert für bestimmte Wirkmechanismen?

- Sind indikative Endpunkte mit populationsrelevanten Endpunkten korreliert?

- Tendieren indikative Endpunkte zu falsch positiven oder falsch negativen Einschätzungen populationsrelevanter Aussagen?

Eine Aussage lässt sich nur durch die parallele Betrachtung von mehreren validen Testergebnissen unterschiedlicher Endpunkte für bestimmte Proben oder Einzelsubstanzen treffen und erfordert den Einsatz von populationsrelevanten In-vivo-Tests (z.B. für Reproduktionstoxizität). Die US-EPA hat 1998 ein Endocrine Disruptor Screening and Testing Advisory Comittee (EDSTAC) einberufen, welches ein stufenweises Vorgehen für eine Bewertung der ca. 87000 kommerziellen Chemikalien und Umweltschadstoffe vorgeschlagen hat (Charles 2004). In Kooperation hat die OECD EDTA Task Force ein 5-stufiges Prüfprogramm entworfen, welches eine Bewertung von endokrinen Disrup- toren ermöglicht (OECD Environment, Health and Safety Division Test Guidelines Programme 2005). Im Vorfeld der Entstehung wurden Berechnungen zur benötigten Anzahl der Versuchstiere mit einem Stufensystem durchgeführt. Dies erfolgte unter Berücksichtigung falsch positiver oder falsch negativer Testaussagen der unteren Bewertungstufen (Gray et al. 2002). Wie praktikabel und effizient dieses Prüfprogramm der OECD für die Einzelsubstanzbewertung sein wird ist offen. Mittlerweile befindet sich dieses Programm in einer komprimierten 2-stufigen Form in der Anwendung und wird noch ergänzt (US-EPA 2008). So wurde z. B. in der ersten Stufe im EDSP-Ansatz versucht die Unsicherheiten, die durch In-vitro- zu In-vivo-Extrapolationen entstehen können, durch eine Kombination von verschiedenen Assays (in vitro und in vivo) mit unterschiedlichen Endpunkten zu adressieren. In einer zweiten Stufe werden dann die Chemikalien, die in der ersten Stufe Effekte verursachten, in Multi-Generations-Studien weiter bewertet. Es ist zu erwarten, dass hiermit ein hoher Erkenntnisgewinn über die Wirkweisen von endokrinen Disruptoren damit verbunden sein kann, sofern die Daten zugänglich gemacht werden.

\subsection{Stufenweises oder modulares Vorgehen}

Ein stufenweises Vorgehen ermöglicht einerseits Flexibilität in der Durchführung, andererseits reduziert es den experimentellen Aufwand, da nur für Substanzen mit ausreichenden Verdachtsmomenten aufwändige In-vivo-Verfahren angewendet werden müssen. Andererseits können Low-dose-, sekundäre sowie verzögerte und Langzeit-Effekte nur mit In-vivo-Verfahren zuverlässig erfasst werden. Daher wäre ein modulares Vorgehen für die Bewertung Umweltproben (parallele Kombination von In-vitro- und In-vivo-Verfahren) aus ökotoxikologischer Sicht zu bevorzugen.

Verschiedene Studien, die vergleichend In-vitro- und In-vivo-Ansätze betrachten, zeigen Probleme in der Übertragbarkeit von $I n$-vitro-Befunden auf organismische $I n$-vivo-Antworten. So wurden verschiedene In-vitro-Verfahren (rtER-YES und hER-YES) zusammen mit der Vitellogenin-Induktion in Dickkopfelritzen (Pimephales promelas) anhand von verschiedenen UV-Filtern untersucht (Kunz et al. 2006b). Sechs dieser UV-Filter waren in vitro in hohen Konzentrationen östrogen aktiv, zwei zeigten keine Aktivität in vitro. Für drei der sechs aktiven UV-Filter konnte auch In-vivo-Östrogenität nachgewiesen werden, und UV-Filter ohne Invitro-Aktivität waren auch in vivo nicht östrogen, was darauf hinweist, dass die benutzten YES-Tests nicht zu falsch negativen Resultaten führten. Falsch positive Aktivitäts-Vorhersagen der In-vitro-Tests könnten jedoch ein Problem sein, denn drei der in vitro östrogenen UV-Filter zeigten in vivo keine östrogene Aktivität. Beide YES-Assays zeigten abhängig von der untersuchten Substanz ähnliche 
aber auch deutlich geringere Sensitivitäten als die organismische Vitellogenin-Induktion. Zusätzlich konnte gezeigt werden, dass die YES-Systeme grundsätzlich auf die gleichen UV-Filter ansprachen, jedoch dabei unterschiedliche Sensitivitäten aufwiesen. Das rtER-YES-System, welches mit einem Regenbogenforellen-Östrogenrezeptor arbeitet, lag näher an der In-vivo-Antwort, obwohl es unempfindlicher auf 17-beta-Estradiol reagierte als das YES-Verfahren mit dem humanen Östrogenrezeptor.

Auch eine andere Studie, die mit YES-Verfahren und In-vivo-Systemen mit Regenbogenforellen angewendet wurden, leitete eine Möglichkeit der Unterschätzung der In-vivo-Antwort für tertiäre Abwasseruntersuchungen $a b$ (Xie et al. 2004). Jedoch wurden die In-vitro-Proben zuvor filtriert und anschließend extrahiert. Eine Veränderung des östrogenen Potenzials durch eine Probenbehandlung kann für diese Studie daher nicht ausgeschlossen werden und zeigt die Notwendigkeit native Proben für Umweltprobenbewertungen $\mathrm{zu}$ verwenden. Die In-vivo-Vitellogenininduktion variiert artspezifisch in Fischen recht stark (Hutchinson 2006). Es scheint davon abhängig zu sein, mit welcher Fischart der Vergleich getroffen wurde. Wie entscheidend Östrogenrezeptoren für die Entwicklung und Funktion von aquatischen Organismen sind, konnte anhand von Zebrabärblingen (Danio rerio) nachgewiesen werden, bei denen ein „Knock Down“ (Ausschaltung bestimmter Gene) erzeugt wurde (Fröhlicher 2008). Die rezeptorvermittelten Antworten tragen neben den anderen Wirkmechanismen (Aromatasehemmung, Modulation der Steroidgenese, usw.) einen Anteil an der endokrinen Disruption, daher sollten diese auch in einem modularen System berücksichtigt werden.

\section{Welche Verfahren können für ein Umweltmonitoring verwendet werden?}

Ein solch umfangreiches Prüfprogramm wie bei der OECDEDTA Task Force ist für ein kontinuierliches Umweltmonitoring nicht $\mathrm{zu}$ realisieren, zudem die meisten der aufgeführten Testverfahren der OECD primär für Einzelsubstanztestungen ausgelegt sind. Für ein Umweltmonitoring sind einerseits Testverfahren zu bevorzugen, die mit möglichst nativen und chemisch-physikalisch unveränderten Proben arbeiten können, damit die natürlichen Expositionspfade, aber auch der Einfluss der Bioverfügbarkeit berücksichtigt werden können. Andererseits sollten (zyto) toxische Effekte getrennt von den hormonaktiven Wirkungen nachgewiesen werden können. Daher wäre eine Kombination aus Testverfahren, die auf molekularer, zellulärer und organismischer Ebene spezifische Endpunkte erfassen, welche gleichzeitig einen hohen Indikationswert für ein breites Organismenspektrum besitzen, wünschenswert (Abb. 12).

Die Testkombination sollte also einerseits Systeme enthalten, die selektiv und wirkungsspezifisch sind, um das toxikologische Potenzial anzuzeigen. Andererseits muss eine Translation des toxikologischen Potenzials in effektiv nachweisbare Effekte auf den Gesamtorganismus oder auf Populationen nachgewiesen werden, um eine vollständige ökotoxikologische Bewertung vornehmen zu können. Besonders die reproduktionstoxischen Effekte können populationsrelevant sein, wobei solche Effekte in Umweltproben sowohl durch hormonaktive als auch durch unspezifisch wirkende toxische Substanzen verursacht werden können. Der Anteil von hormonaktiven Wirkungen an einer Reproduktionstoxizität kann identifiziert werden, indem hormonaktive und

\begin{abstract}
Abb. 12 Vorgeschlagene modulare Testverfahren zur Erfassung hormonaktiver und fortpflanzungsgefährdender Wirkungen, nach dem derzeitigen Entwicklungsstand
\end{abstract}

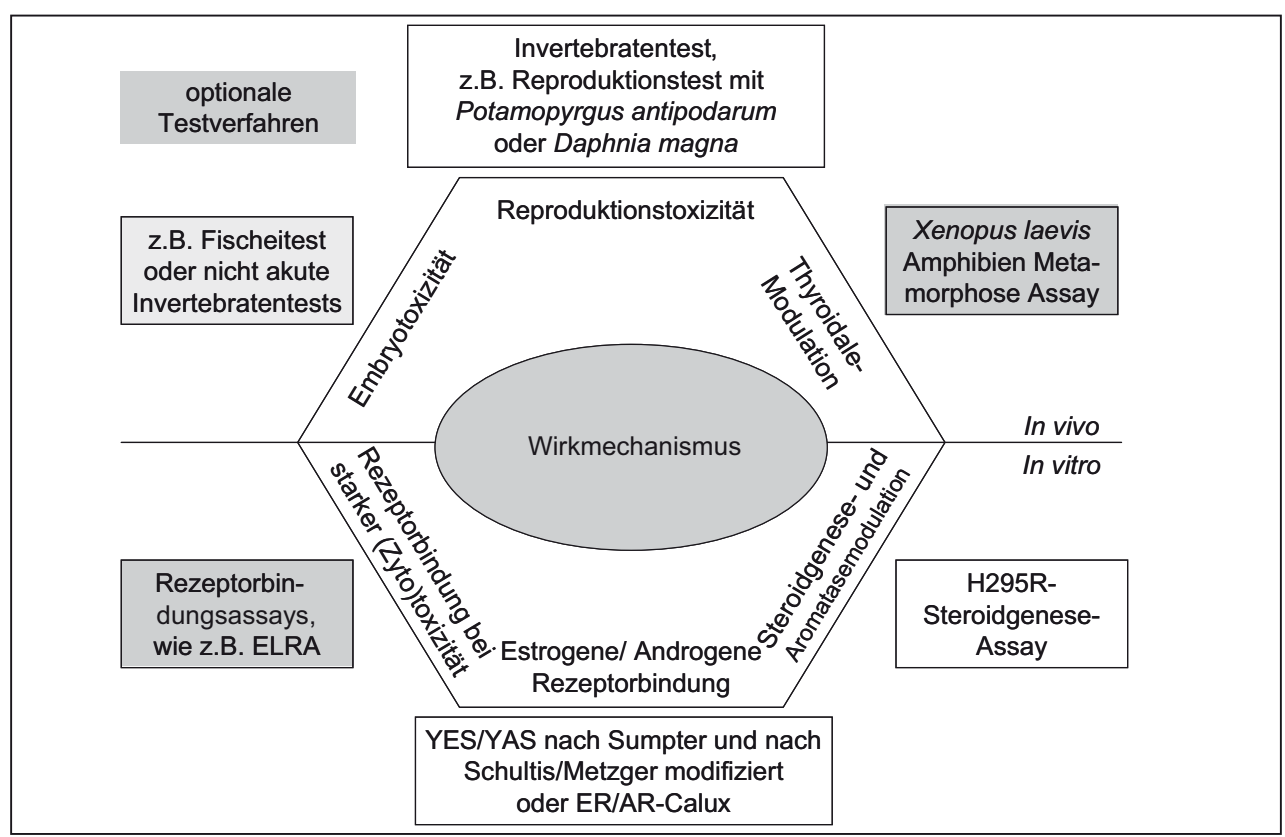


subchronische allgemeintoxische Effekte parallel detektiert werden.

Generell werden gut untersuchte oder gut untersuchbare Arten für Testsysteme verwendet, wobei die Relevanz für heimische Ökosysteme nur selten berücksichtigt wurde. Daher ist der Entwicklungsstand der Testverfahren für bestimmte Arten (z. B. Danio rerio, Xenopus laevis oder auch Potamopyrgus antipodarum) wesentlich weiter als für heimische Arten, was die Auswahl der Testverfahren mit beeinflusst hat.

Eine umfangreiche Literaturrecherche $\mathrm{zu}$ Testsystemen für Gammariden ergab, dass es in dieser für Fließgewässer strukturell und funktionell bedeutenden Artengruppe einige EDC-indikative Endpunkte für eine ökotoxische Risikobewertung in Oberflächengewässern geben könnte (Kunz et al. 2009). Tests mit Invertebraten sind zu befürworten, um ethisch umstrittene Wirbeltiertests zu minimieren. Zudem machen Invertebraten mehr als $95 \%$ der bekannten Spezies aus (Oehlmann und Schulte-Oehlmann 2003), womit phylogenetisch konservierte Mechanismen vorrangig untersucht werden sollten, da diese auf ein größeres Artenspektrum übertragbar sind. Neben der Arten- und Biomasse-bezogenen Bedeutung der Invertebraten ist es wichtig zu erwähnen, dass Vertebratentests in Zukunft stark eingeschränkt werden sollen.

Allerdings sind die Mechanismen der endokrinen Disruption zwischen Invertebraten und Vertebraten derartig unterschiedlich, dass dadurch Schutzziele für Vertebratenpopulationen insbesondere für Fische verfehlt werden könnten. Andere Testverfahren, die vertebratenrelevante Wirkmechanismen zuverlässig abdecken, sind ebenfalls notwendig. Es bleibt zu prüfen, inwieweit z. B. die zellulären Rezeptorbindungsassays oder der H295R Steroidgenesis Assay dies vermögen.

Betrachtet man z. B. nur die Rezeptorbindungen an Östrogen-und Androgenrezeptoren, so gehen unter Umständen die Wirkmechanismen der Aromatasehemmung, der Beeinflussung des Thyroidstoffwechsels oder der Steroidgenese verloren, welche sich auf die hormonelle Gleichgewichtslage von Organismen auswirken können. Ebenso werden mögliche Bioaktivierungen oder auch Inaktivierungen durch Metabolisierungs- und Ausscheidungsreaktionen mit In-vitro-Ansätzen oftmals nicht berücksichtigt. Dennoch ermöglichen In-vitro-Ansätze als Screeningverfahren im Bezug auf eine schnelle und valide Datengenerierung (siehe Tabelle 1 und Abb. 2) einen effizienten Weg um wirkmechanistische Betrachtungsweisen für potenzielle endokrine Disruptoren zu untersuchen. Eine Abschätzung, welche Mechanismen sich auch im neuroendokrinen System der Hypothalamus-Hypophysen-Gonaden-Achse manifestieren, ist jedoch nicht möglich. Das hier vorgeschlagene modulare System hat versucht, unterschiedlichen Wirkmechanismen und unterschiedliche In-vivo-Effekte zu berücksichtigen und in ihren Stärken zu kombinieren, die im Einzelnen diskutiert werden.

\subsection{In-vitro-Module}

\subsubsection{Molekulare Rezeptorbindungsassays/Biosensoren}

Gerade die In-vitro-Verfahren erlauben eine stärkere Trennung der spezifischen Antwort von allgemeintoxischen Effekten, da sie auf der zellulären Ebene die Möglichkeit besitzen entweder mit variablen Verdünnungsstufen oder sogar mit Extrakten zu arbeiten. Teilweise können zytotoxische Effekte, bzw. eine Wachstumshemmung getrennt von der spezifischen Antwort angezeigt werden. Misst man direkt auf der molekularen Ebene, z. B. mit Rezeptorbindungsassays, so fallen zytotoxische Überlagerungen sogar gänzlich weg. Auf die unterschiedlichen Arbeitsweisen von Rezeptorbindungsassays und zellulären Systemen wurde im Ergebnisteil eingegangen. Insgesamt sind Rezeptorbindungsassays zu bevorzugen, wenn starke zytotoxische Effekte oder mikrobielle Kontaminationen eine Anwendung der zellulären Assays behindern, da es dort zu Überlagerungen der Effekte kommen kann. Eine Probe muss dann in der Regel in einem zellulären Assay so stark verdünnt werden, bis das Wachstum der Zellen Validitätskriterien erfüllt. Eine Probenverdünnung reduziert die Toxizität, aber ebenfalls die Möglichkeit östrogene Effekte zu detektieren (Kinnberg 2003). Rezeptorbindungsassays können als biochemische Verfahren daher gute Alternativen sowohl für eine Erfassung der agonistischen, als auch der antagonistischen Rezeptorbindung sein. Eigene Erfahrungen für Umweltprobenbewertungen liegen jedoch nur für den ELRA (Kase et al. 2007, 2008) vor, der mit dem humanen Östrogenrezeptor-alpha arbeitet und in hohen Verdünnungsstufen Rezeptorbindungspotenziale in wässrigen Umweltproben nachweisen kann. Eine Erweiterung um einen Androgenrezeptor wäre möglich und anzuregen, doch werden vielleicht zukünftig Biosensoren integral Rezeptorbindungen erfassen können, wie es neuere Studien aufzeigen (Fechner et al. 2008). Ebenfalls zu erwägen ist eine Kombination von ER/ AR-Rezeptorbindungsassays der EDTA-Task-Force (siehe Tabelle 4), da OECD-Verfahren die Vorzüge einer OECDValidierung mitbringen könnten. Inwieweit diese sich für Umweltprobentestungen eignen, müsste untersucht werden. Für eine Risikobewertung dürfen molekulare Rezeptorbindungsassays nicht als alleinige Testverfahren eingesetzt werden, da sie erstens nur auf der biochemischen Ebene Rezeptorbindungen anzuzeigen vermögen und zweitens keine Wirkrichtungsunterscheidung zulassen. Sie sollten daher als ergänzende Verfahren bei (zyto)toxischen Überlagerungen eingesetzt werden oder ermöglichen ein umfangreiches und kostenschonendes Probenscreening, um innerhalb kurzer Zeit belastete Hot-Spots zu identifizieren. 


\subsubsection{Zelluläre Rezeptorbindungsassays}

Da zelluläre Biotests integrativ Rezeptorbindungen erfassen, ist eine Bewertung der Sensitivität der Biotests für Umweltmatrizes komplexer als bei molekularen Rezeptorbindungsassays und erfordert Ringtestungen von nativen und dotierten Proben mit unterschiedlichen Testverfahren. Für den ER-Calux und den YES bestehen Vergleichsstudien mit Einzelsubstanzen, Oberflächenwasser-, Abwasser- und Sedimentextrakten, die eine gute Korrelation der ermittelten Östrogenitätswerte zeigen (Murk et al. 2002). Aufgrund des tieferen Detektionslimits und der daraus resultierenenden geringeren benötigten Probenvolumina wurde der ER-Calux in dieser Studie für Umweltprobentestungen als vorteilhaft dargestellt.

Eine weitere Einschätzung der Stärken und Schwächen des ER-Calux und der bestimmten YES-Verfahren befindet sich in Tabelle 2. Als Grundlage wurden Einzelsubstanz-, Umweltproben- und dotierte Umweltprobentestungen durchgeführt. Doch wurden in dieser Studie (Leusch et al. 2008) relativ unempfindliche YES-Varianten eingesetzt (mit Nachweisgrenzen von 3,5 und 5 ng/1 17-beta-Estradiol) und ebenfalls überwiegend mit Umweltprobenextrakten gearbeitet. Beide Vergleichsstudien empfehlen den ER-Calux als besonders sensitives Verfahren. Calux-Systeme arbeiten mit gentechnisch veränderten humanen Brustkrebszellen oder mit genetisch veränderten Knochenmarkszellen, wobei diese Verfahren von der OECD derzeit validiert werden. Die Calux Verfahren zeigten auch unter den untersuchten $I n$ - vitro-Systemen die höchste Sensitivität für Einzelsubstanzen (siehe Abb. 9) und relativ geringe Variationskoeffizenten für Intertest-Umweltprobentestungen $(<20 \%)$. Nachteilig ist, dass diese Tests kommerziell angeboten werden und aufwendiger in der Handhabung sind, was einer Verbreitung dieser Testsysteme entgegensteht. Als nicht-kommerzielles Analogon zum ER-Calux wird eventuell der T47D-KbluC zukünftig von der OECD validiert, welcher von der US-EPA befürwortet wird; eine ähnlich empfindliche Variante und bereits fast validiert ist der TA-assay (siehe Tabellen 1 und 4).

Bei der Wahl eines zellulären Assays sollte außerdem berücksichtigt werden, dass es z. B. bei einer Ozonung als Abwasserbehandlung zu einer Minimierung der östrogenen und einer Erhöhung der androgenen Rezeptorbindung kommen kann (Schwätter et al. 2007). Systeme, die parallel östrogene und androgene Rezeptorbindungen detektieren können, sollten daher bevorzugt werden, zumal es keinen großen zusätzlichen Arbeitsaufwand bedeutet, beide Verfahren parallel zu nutzen. Auf der zellulären Ebene wird die Auswahl damit auf YES/YAS und ER/AR-Calux-Systeme begrenzt.

Anwendungsgrenzen der hefebasierten Systeme Eine große Verbreitung weisen die YES-Systeme auf, allerdings werde viele unterschiedliche Verfahren angewendet, wobei mehrere relativ unsensitiv auf Einzelsubstanzen reagieren (siehe Tabelle 1), was die Auswahl eines geeigneten Verfahrens erschwert. Ein YES/YAS-System nach McDonnell befand sich ebenfalls schon in Normierungen des DIN-Arbeitskreises „Endokrine Wirkungen“, doch unterliegt dort die YAS-Komponente stärker Wachstumsproblemen und zytotoxischen Effekten in Umweltproben (Kase 2004). Allerdings ist die YES-Komponente ausreichend robust, um von der deutschen Bundesanstalt für Gewässerkunde zur ökotoxikologischen Bewertung von belasteten Sedimenten eingesetzt zu werden. Oberflächensedimente werden so als „Gedächtnis“ des partikulären Materials der Wasserphase genutzt und zeigen bei belasteten Probenahmestellen kontinuierlich ähnlich erhöhte östrogene Aktivitäten an (in Porenwässern, wässrigen Eluaten und Extrakten). Auf die Gefahr von toxischen Maskierungen von estrogenen Effekten im YES wird in einer kürzlich erschienenen $\mathrm{Pu}-$ blikation (Frische et al. 2009) eingegangen, diese zeigt die Notwendigkeit estrogene und zytotoxische Effekte parallel $\mathrm{zu}$ erfassen um falsch negative Ergebnisse ausschliessen zu können. Zu berücksichtigen ist auch, dass die Hefezellwand sich strukturell stark von pflanzlichen und tierischen Zellsystemen unterscheidet und damit auch eine veränderte Durchlässigkeit für EDC-aktive Substanzen besitzt. Eine Übersicht zu den ökotoxikologischen Bewertungsverfahren von Sedimenten befindet sich in Manz et al. (2007). Eine Literaturrecherche und die Abfrage zeigten, dass einige YES/ YAS-Systeme ohne vorherige Probenaufkonzentration/Extraktion Rezeptorbindungen in Abwasser, Sedimenteluate, Porenwasser und sogar belastete Oberflächenwasser unterhalb von Kläranlagen nachzuweisen vermögen. Besonders vielversprechend aufgrund der geringen Variationskoeffizienten bei Mehrfachmessungen für Einzelsubstanzen und Umweltproben und der angegebenen Sensitivität für Einzelsubstanzen (LOEC von 0,49ng/1 17-beta-Estradiol und $90 \mathrm{ng} / \mathrm{l}$ Testosteron) scheint das YES/YAS-System nach Sumpter (Routledge und Sumpter 1996), modifiziert mit einem Lyticase-katalisierten Endverdau nach Schultis/Metzger (Schultis und Metzger 2004) zu sein (zum Vergleich siehe Tabelle 1).

Ebenfalls wurden empfindliche YES-Varianten nach Sumpter (Nachweisgrenzen: 0,1-0,2 ng/l 17-beta-Estradiol) für Östrogenitätsstudien in der Schweiz verwendet (Vermeirssen et al. 2006). Der Fluss Lützelmurg wurde in der Nähe einer Kläranlage bei Aadorf untersucht. Oberhalb der Kläranlage wurden in 50\% der Fälle 17-beta-Estradioläquvivalente (EEQ) nahe der Detektionslimits gemessen. Die Östrogenität im Auslauf der Kläranlage lag zwischen 0,2 und 7,7 ng/1 EEQ, mit Mittelwerten, die in den vier Probenahmeintervallen zwischen 1,5 und 3,9 ng/l EEQ schwankten. Unterhalb der Kläranlage $(0,5 \mathrm{~km})$ lagen die Messwerte bei über $95 \%$ der Proben über der Nachweisgrenze und erreich- 
ten im Mittel 0,82 $\pm 0,07 \mathrm{ng} / 1$ EEQ. Dieses Ergebnis zeigt, dass einige besonders empfindliche YES-Varianten sensitiv genug sind, um Östrogenität im Auslauf der Kläranlage und $0,5 \mathrm{~km}$ flussabwärts anzuzeigen, für andere Anwendungen jedoch an ihre Detektionsgrenzen geraten können. Ebenfalls wurde im NFP50 die Östrogenität von Schweizer Flusssystemen und Abwässern mit dem YES-System nach Sumpter erfasst (Vermeirssen et al. 2008). Zusammenfassend konnten bei diesen Untersuchungen hohe Variabilitäten der östrogenen Aktivität gemessen werden, wobei diese vergleichbar zu anderen Ländern lag. Um integrativ östrogene Aktivitäten in Flusssystemen zu erfassen, wurden im NFP50 Polar Organic Chemical Integrated Sampler (POCIS) als geeignete passive Probennehmer identifiziert (Vermeirssen et al. 2006; Vermeirssen et al. 2008).

Einfluss verschiedener Rezeptortypen Für viele östrogene und androgene rekombinante Verfahren (wie z.B. YES/ YAS, ER/AR-Calux) werden überwiegend humane Rezeptoren eingesetzt (siehe Tabelle 1), so dass eine direkte Übertragbarkeit der Ergebnisse auf aquatische Organismen eingeschränkt wird, aber einen höheren Stellenwert für die menschliche Gesundheit einnehmen könnte. Die Verbreitung und die aktuelle Anwendbarkeit von auf Fischrezeptoren basierenden Testverfahren, einerseits in zellulären Rezeptorbindungsassays (Ackermann et al. 2002a; Rutishauser et al. 2003), andererseits als Hefeassay (Kunz et al. 2006b; Petit et al. 1995), konnte trotz Bemühungen nicht abgefragt werden. Allerdings entsteht derzeitig für die OECD ein Review (OECD 2009, in Vorbereitung) für Testverfahren basierend auf Fischrezeptoren. Die YES/YAS und ER/AR-Calux-Systeme sind insgesamt besser als die Fischrezeptoren-Tests untersucht und verbreitet (siehe Tabellen 1 und 4), und zeigen so den aktuellen Stand der Technik und der Anwendbarkeit. Das Schutzziel sollte die Anwendungsentscheidung bestimmen. Allgemeiner Konsens besteht jedoch, dass es praktisch unmöglich ist, mit gängigen Testverfahren Qualitätskriterien festzulegen, die alle Organismen vor nachteiligen Effekten schützen (FNSNF 2008b). Das beinhaltet sowohl Tests mit Säuger- und Fischrezeptoren als auch andere Testverfahren.

Die vorgeschlagenen zellulären Rezeptorbindungsassays (YES/YAS und der ER/AR-Calux) vermögen aufgrund der geringen Versuchsdauer integrativ akute Veränderungen der Östrogenität und Androgenität in verschiedenen Umweltmatrizes anzuzeigen. Der YES oder der ER-Calux werden auch im Schlussbericht der Eawag zur Ableitung von toxikologisch begründeten Qualitätskriterien für östrogenartig wirkende Stoffe (Escher und Vermeirssen 2008) als gut etablierte Verfahren für ein Umweltmonitoring empfohlen. Dennoch kann eine Proben-Extraktion zu einer Reduzierung der gemessenen Östrogenität von hormonaktiven Substanzen, wie z.B. 17-beta-Estradiol führen (Escher und Vermeirssen 2008). Durch Extraktionen können sich die Pro- benmatrix und das Wirkgefüge der Inhaltsstoffe verändern, womit eine bioverfügbare Wirkung nicht erfasst, sondern lediglich Wirkungspotenziale abgebildet werden können. Eine emissionsbezogene Überwachung, z.B. für Abwasser mit einem validen, sensitiven und ausreichend robusten Testverfahren, wäre wünschenswert. Die Eignung der vorgeschlagenen YES/YAS- und ER/AR-Calux-Testverfahren könnte im Rahmen von Normierungsverfahren auf unterschiedliche native und dotierte Umweltmatrizes geprüft werden, doch ist auch die Entwicklung von weiteren frei zugänglichen Testverfahren anzuregen.

\subsubsection{Steroidgenese/Aromatasemodulation}

Eine Störung des hormonellen Gleichgewichts kann auch durch Modulationen der Steroidgenese oder der Aromataseaktivität auftreten. Beide Mechanismen sind im Tierreich sowohl bei Invertebraten als auch bei Vertebraten verbreitet und bieten eine Angriffsfläche für endokrine Disruptoren. Im Rahmen des EDSP und eines OECD-Validierungsprogramms wurde ein Screeningverfahren untersucht und validiert, welches Einfüsse auf die Steroidgenese an humanen Adenokarzinomzellen nachweisen kann. Dabei können Effekte entlang der gesamten Steroidsynthese-Kaskade einschließlich Metabolismus erfasst werden. Da die Steroidsynthese-Kaskade in den meisten Vertebraten identisch ist, können teilweise Effekte angezeigt werden, die direkt mit denen in Organsimen vergleichbar sind. Der H295R Steroidgenesis Assay wurde bereits in Inter-Labor-Ringversuchen mit sechs Laboratorien aus fünf Nationen erfolgreich als robust, übertragbar und reproduzierbar validiert (Hecker et al. 2007a) und wird derzeitig als OECD-Draft-Testguideline eingereicht. Als Referenzsubstanzen werden Induktoren und Inhibitoren der Steroidgenese (Forskolin, Prochloraz) in einem 24-Well-Mikrotiterplattenformat verwendet und die Produktion von Testosteron und 17-beta-Estradiol wird mittels ELISA, Radioimmunoassays oder LC-MS-Analyse durchgeführt. Zusätzlich kann eine Zellvitalität ermittelt werden. Nicht validiert, aber dennoch möglich ist es, das Verfahren in einer veränderten Variante parallel durchzuführen und Einflüsse auf die Aromataseaktivität nachzuweisen (Hecker et al. 2007b). Dreißig Verbindungen, von denen teilweise ein Einfluss auf die Steroidgenese bekannt ist, wurden mit diesem Verfahren erfolgreich getestet und es laufen weitere Experimente für aquatische Umweltprobentestungen. 2005 wurden bereits 24 marine Küstengewässerproben und Abwässer von zwei Abwasserkläranlagen mit dem H295R Steroidgenesis Assay untersucht (Gracia et al. 2008), doch mussten hohe Aufkonzentrierungen der Proben durch Extraktionen durchgeführt werden um überhaupt Effekte auf die Steroidgenese nachzuweisen. Hingegen konnten ohne hohe Aufkonzentrierungen bei der Untersuchung von Sedimentproben aus der Donau sowohl stimulierende 
als auch inhibitorische Effekte auf die Synthese von 17-beta-Estradiol und Testosteron erfasst werden (Grund et al., in Vorbereitung; Higley et al., in Vorbereitung). Für den Wirkmechanismus der Steroidgenese gibt es in vitro keine Alternativerfahren. Für die Aromatasemodulation sind die Möglichkeiten ebenfalls sehr begrenzt und funktionieren entweder mit menschlichen placentalen Mikrosomen (Andersen et al. 2002) oder mit der menschlichen Tumorzelllinie KGN (Nishi et al. 2001). Sollte sich der H295R Steroidgenesis Assay in anderen Umweltprobentestungen, z. B. direkten Abwassertests, als ausreichend sensitiv erweisen, würde er die Möglichkeit bieten die Wirkmechanismen der Steroidgenesemodulation, und bei ausreichender Validität auch der Aromatasemodulation, mit einem Testverfahren als potenzielle Angriffsflächen für endokrine Disruptoren abzudecken. Als valides und OECD-genormtes Testverfahren wäre es trotz der Verwendung von Extrakten ein besonders interessantes Testverfahren für eine modulare Testpalette, da es als In-vitro-Verfahren die vielfältigen Detektionsmöglichkeiten der rezeptorvermittelten Wirkungen sinnvoll ergänzen kann.

\subsection{In-vivo-Module}

\subsubsection{Problematik der Fischtests}

Der in OECD-Validation befindliche FSA beinhaltet mehrere Endpunkte, wie Vitellogenin-Induktion, sekundäre Geschlechtsmerkmale, Reproduktion (Eizahl) und optional Gonadenhistologie (OECD 2008a). Danio rerio reagiert mit mehreren dieser Endpunkte auf umweltrelevante 17-betaEstradiol-Konzentrationen (im unteren ng/l Bereich) (Segner et al. 2003) und kann Effekte differenziert aufzeigen. Thyroidale Effekte vermag der FSA jedoch nicht anzuzeigen, und es handelt sich um einen aufwändigen und bewilligungspflichtigen Vertebratentest. Die unterschiedlichen, teilweise artspezifische Empfindlichkeiten (Danio rerio, Pimephales promelas, oder Oryzias latipes) für bestimmte Wirkmechanismen und Endpunkte werfen zusätzliche Fragen auf, die nur bei ausreichender Kenntnis des Testverfahrens zu beantworten sind. Die diversen Endpunkte im FSA könnten sich aus regulatorischer Sicht als problematisch erweisen, da geklärt werden muss, welche dieser Parameter in eine gesetzliche Umweltrisikobewertung einbezogen werden sollte (Knacker et al. 2007). Der Biomarker Vitellogenin beispielsweise kann als wertvoller mechanistischer Warnhinweisgeber verstanden werden, um Entscheidungen für chronische Testungen zu treffen (Hutchinson et al. 2006). Man sollte ihn jedoch nicht isoliert für Risikobewertungen heranziehen. Zum jetzigen Zeitpunkt existiert auf regulatorischer Ebene kein national oder international hinreichend etabliertes Verfahren, das zwingend zum Nachweis eines begründeten Verdachtes auf endokrine Wirksamkeit einer
Substanz bei Fischen angewendet werden muss (Schäfers et al. 2008) und auch keine dafür akzeptierte Prüfstrategie. Das deutsche Umweltbundesamt hält jedoch die verfügbare Datenlage zum FSA für ER-Agonisten und Aromatasehemmer für ausreichend, um falsch negative Ergebnisse mit der erforderlichen Sicherheit auszuschließen (Schäfers et al. 2008). Ebenfalls ist anzunehmen, dass die gewählten In-vitro-Module bereits einen Teil der vertebratenrelevanten östrogenen und androgenen Effekte erkennen können, daher ist der FSA nicht in der modularen Testpalette vertreten. Trotz der Sensitivität des FSA in mehreren Endpunkten können wir ihn aufgrund der internationalen Bestrebungen Vertebratentests zu minimieren und aufgrund des großen Arbeitsaufwands nicht für ein Umweltmonitoring empfehlen.

Möchte man Vitellogenin bei In-situ-Untersuchungen an heimischen freilebenden Arten für eine Expositionsabschätzung nutzen, so sollten bestimmte Faktoren berücksichtigt werden (verändert nach Segner 2009):

- Die Vitellogenin-Antwort kann neben den EDC-Wirkungen auch durch andere physiologische Zustände der Versuchstiere (Saisonalitäten, Umweltfaktoren) beeinflusst werden.

- Der zeitliche Verlauf der Biomarker-Antwort sollte bekannt sein (z. B. Dauer der Induktion und Adaptation).

- Um Migrationseffekte und Variabilitäten zu minimieren, sind die Versuchstiere standortstreu zu hältern.

- Eine Kombination der Biomarker-Messungen mit Invitro-Verfahren und einer chemischen Analytik ist vorzuziehen.

\subsubsection{Thyroidale Modulation}

Obwohl viel Forschung an Amphibien über endokrine Disruption, hauptsächlich durch östrogene Substanzen an Effekten auf die Reproduktion durchgeführt wurde, wird ein Einfluss auf das Thyroid-System, welches den Metamorphoseablauf steuert, als stärkerer Faktor in deren Populationsökologie eingeschätzt als eine mittlere Verschiebung des Geschlechterverhältnisses (Kloas 2002). Amphibien werden als beste Modelle unter den Vertebraten eingeschätzt um eine endokrine Disruption des Thyroidsystems mit einfach messbaren Endpunkten zu bewerten. Da die Einflüsse auf das Thyroid-System sehr unterschiedlich und komplex sein können, werden In-vivo-Tests als geeignetere Testansätze verstanden um thyroidale Modulationen über eine beschleunigte oder verlangsamte Metamorphose anzuzeigen. Der südafrikanische Krallenfrosch Xenopus laevis wird als Modellorganismus für Amphibien verwendet und reagiert z. B. erst bei relativ hohen Konzentrationen an Östrogenen und Androgenen mit einer Verschiebung seines Geschlechterverhältnisses $\left(10^{-8} \mathrm{~mol} / 1 \mathrm{E} 2 ; 10^{-8} \mathrm{~mol} / 1 \mathrm{EE} 2\right.$, $10^{-8} \mathrm{~mol} / \mathrm{l}$ DHT) (Kloas 2002). Ebenfalls wird das Überleben der Embryonen auch bei relativ hohen Konzentrationen 
$\left(10^{-5} \mathrm{~mol} / 1 \mathrm{E} 2,>10^{-5} \mathrm{~mol} / \mathrm{l} \mathrm{EE} 2,10^{-5} \mathrm{~mol} / 1\right.$ Diethylstilbistrol) an östrogenen und auch androgenen Substanzen, wie Dihydrotestosteron (DHT) beeinflusst (Nishimura et al. 1997). Hingegen vermag der Assay Beeinflussungen des Thyroidstoffwechsels sensitiv über einen veränderten Metamorphoseablauf anzuzeigen (Kloas 2002). Der Amphibien-Metamorphose-Assay mit Xenopus laevis, auch XEMA, steht kurz vor der offiziellen Verabschiedung als OECDRichtlinie (siehe Tabelle 4). Da das Testverfahren erst bei relativ hohen Konzentrationen auf östrogene und androgene Steroidhormone anspricht, stellt es eine gute Ergänzung $\mathrm{zu}$ den östrogenen und androgenen Wirkmechanismen in der modularen Testpalette dar, da Überlagerungseffekte vermieden werden können. Die Versuchsdauer des XEMA beträgt drei Wochen, doch sind Vortestungen und Auswertungen relativ arbeits- und zeitaufwändig. Eine vielfältige Anwendbarkeit für Umweltmatrizes wurde angegeben (siehe Abb. 10). Neben morphologischen Parametern für den Metamorphoseablauf besteht die Möglichkeit den XEMA um eine Schilddrüsenhistologie oder Genexpressionsanalysen (z. B. auch Vitellogenininduktion (Kloas et al. 1999) zu erweitern. Es ist derzeit nicht möglich den Stellenwert einer thyroidalen Modulation im Bezug auf andere Mechanismen der endokrinen Disruption anzugeben. Um diesen Wirkmechanismus erfassen zu können, wäre ein Nachweis in einer modularen Testpalette möglich, obwohl zu bedenken ist, dass Vertebratentests generell minimiert werden sollen.

Neuere Entwicklungen von Testverfahren an Echinodermaten (Heart-Urchin-ELS) zeigen, dass es ebenfalls möglich ist, thyroidale Modulationen schon in Invertebratensystemen nachzuweisen. Der Heart-Urchin-ELS betrachtet die Embryonalentwicklung der Versuchstiere in 24 Well-Mikrotiterplatten über eine Versuchsdauer von 10 Tagen. Die technischen Möglichkeiten zur Verfolgung der Embryonalentwicklung und deren Auswertung werden derzeitig untersucht (Murk 2009). Ebenfalls zu erwähnen ist, dass es auf zellulärer Ebene kommerzielle Calux-Rezeptorbindungsassays für die Thyroidrezeptoren alpha und beta gibt. Da die thyroidale Antwort jedoch komplex ist, können somit wahrscheinlich nur Wirkpotenziale abgebildet werden, was einen Einsatz für Screening Anwendungen ermöglicht.

\subsubsection{Embryo- und Entwicklungstoxizität}

Sollten in Umweltproben starke unspezifische toxische Effekte zu erwarten sein, die eine Anwendung der anderen Invivo-Module verhindert, so wäre ein valides Testverfahren notwendig, welches diese Toxizität frühzeitig anzeigt. Hierbei kann der umfassend OECD-, DIN- und ISO- normierte Fischeitest (ISO FDIS 15088 2007; siehe auch Tabelle 4) als schnell durchzuführender In-vivo-Test eingesetzt werden ohne adulte Fische einsetzen zu müssen. Er erlaubt embryotoxische Effekte nachzuweisen, die ebenfalls fort- pflanzungsrelevant sein können, und wird in der deutschen Abwasserverordnung nach DIN 38415-T6 eingesetzt.

Es werden Fischeier des Zebrabärblings Danio rerio eingesetzt und deren Überleben nach $48 \mathrm{~h}$ bestimmt. Die Verdünnungsstufe der Probe, bei der mehr als $90 \%$ der Fischeier überleben, wird als nichteffektive Verdünnungsstufe angegeben. Als Referenzsubstanz für den Test dient 3,4-Dichloranilin. Mit 48 h wird nur ein relativ kurzes Expositionsfenster erfasst, was dazu führen könnte, dass später auftretende toxische Effekte wie z. B. Deformationen bei der Entwicklung nicht erfasst werden. Hierzu wäre die Einbeziehung von weiteren, sensitiveren, entwicklungsrelevanten Parametern, ohne den Test zu verlängern, zu empfehlen. Hohe Konzentrationen an EDCs und deren Metabolite, wie z.B. Nonylphenol können im akuten Fischeitest subletale und letale Effekte verursachen (Kammann et al. 2009).

Theoretisch könnten der Fish Early Life Stage Test (ELST) nach OECD 210 oder der Fish Juvenile Growth Test nach OECD 215 alternativ angewendet werden, um Einflüsse auf die (Embryonal- und Larval-) Entwicklung von Fischen nachzuweisen, doch würde sich bei beiden Verfahren der Zeit- und Arbeitsaufwand deutlich steigern (siehe Tabelle 4). Um zukünftig ethisch umstrittene, bewilligungspflichtige Vertebraten-Tests zu minimieren und gleichzeitig heimische aquatische Schlüsselarten zu verwenden, sollte nach möglichen alternativen Invertebratentests zum Nachweis von endokrinen und fortpflanzungsrelevanten Wirkungen Ausschau gehalten werden und deren Entwicklung gefördert werden. Die OECD (OECD 2006b) hat ein detailliertes Reviewpaper veröffentlicht, das sich mit der Eignung von Invertebraten zum Nachweis von Entwicklungs-, Reproduktions- und endokrinen Effekten befasst. Da immer mehr vertebratenähnliche Steroidhormone in einigen Invertebraten gefunden werden, wurden nicht akute (subchronische oder chronische) Invertebratentests als Alternativen angegeben, auch wenn diese kein Ersatz für einen Vertebratentest sind. Ein Vertreter der Crustaceen, wie z. B. der Amphipode Gammarus pulex, könnte zu einem vielversprechenden ModellOrganismus werden, insbesondere auch wegen ihrer ökologischen Relevanz in europäischen Gewässern (OECD 2006b). Erste Resultate aus Feld- und Laborstudien mit Gammariden weisen darauf hin, dass Endpunkte wie die Induktion des Heat Shock Proteins 90 und Vitellogenin, sowie auch das Geschlechter-Verhältnis und die Gonaden-Histologie, als Anzeiger für endokrine Effekte genutzt werden könnten (Kunz et al. 2009; Watts et al. 2002; Gross et al. 2001).

\subsubsection{Reproduktions- und Invertebratentest}

Invertebraten stellen einen Großteil der bekannten Arten. Die Gruppe der Mollusken beträgt mehr als 130000 rezente Arten, wovon ungefähr $85 \%$ zu den Gastropoden zählen (Oehlmann et al. 2007). Auch wenn die genauen Mechanis- 
men der endokrinen Disruption in Gastropoden noch diskutiert werden (Oehlmann et al. 2007), so stellt wahrscheinlich die Aromatasehemmung eine wichtige Angriffsfläche dar. Bei Mollusken, die über generell schwächere Metabolisierungsreaktionen verfügen als Vertebraten, können auch stärkere Bioakkumulationseffekte auftreten. Mit Potamopyrgus antipodarum konnte bereits ein Effektmonitoring an Sedimenten durchgeführt werden (Schulte-Oehlmann et al. 2001). Der Reproduktionstest mit Potamopyrgus antipodarum befindet sich in einer frühen Prävalidierungsphase der OECD. Eine Zählung der Embryonen in der Bruttasche der Schnecken dient als einfach zu bestimmender Endpunkt und bietet die Möglichkeit stimulierende und hemmende reproduktionsrelevante Effekte nachzuweisen. Jedoch kann es zu Überlagerungen mit allgemeintoxischen Effekten oder saisonalen Rhythmen kommen (Duft et al. 2007). Entgegen der verbreiteten Meinung reagieren Schnecken (Potamopyrgus antipodarum, Marisa cornuarietis, Nassarius reticulatus) nicht nur auf Organozinnverbindungen, sondern auch vielfältig auf nachgewiesene östrogene und androgene aktuelle Belastungspotenziale in umweltrelevanten Konzentrationen (Duft et al. 2007). So belegen neuere Studien, dass Potamopyrgus antipodarum auch in der Lage ist, das östrogene Potenzial von UV-Filtern über Erhöhungen der Embryonenzahl anzuzeigen (Schmitt et al. 2008). Eine östrogene Aktivität von UV-Filtern konnte auch im Rahmen des NFP50 in vitro und in vivo an Fischen nachgewiesen werden (Kunz et al. 2006b). Es handelt sich also um ein Invertebratensystem, welches eine hohe Empfindlichkeit für vertebratenrelevante geschlechtshormonaktive Substanzen (z. B. Methyltestoteron, Fenamirol, Bisphenol A, Octylphenol, Ethinylestradiol) besitzt; damit ergänzt es sich gut mit dem XEMA, der vorwiegend thyroidale Modulationen anzeigt.

Ebenfalls in der OECD-Validierung befinden sich zwei Copepoden-Life-Cycle-Tests (Kusk und Wollenberger 2007; siehe auch Tabelle 4). Copepoden (Ruderfußkrebse) bilden mit ca. 14000 Arten die artenreichste Gruppe der Crustaceen. Aufgrund der geringen Größe und der geringen Generationszeit (17-18 Tage von Ei zu Ei) kann Amphiascus tenuiremis im 96 Well-Mikrotiterplattenformat für Untersuchungen eingesetzt werden. Sofern beide Tests die erforderlichen Eigenschaften für ein Umweltmonitoring besitzen, könnten diese eventuell für marine Umweltproben mit mittlerer und hoher Salinität eingesetzt werden.

Der OECD-genormte Daphnien-Reproduktionstest (der derzeit um endokrine Endpunkte erweitert wird) und der Reproduktionstest mit Potamopyrgus antipodarum sind im Vergleich zu dem bereits OECD-genormten und in der Erweiterung befindlichen Chironomidentest variabel für Sediment-, Abwasser und Oberflächenwasser anwendbar (siehe Abb. 10). Weitere Vorteile des Daphnien-Reproduktionstests liegen in seiner weiten Verbreitung, da dieser bereits für die europäische Pflanzenschutzmittelrichtlinie zum Ein- satz kommt. Außerdem ist der Daphnien-Reproduktionstest mit einer dreiwöchigen Versuchszeit schneller als der Reproduktionstest mit Potamopyrgus antipodarum (4-8 Wochen). Derzeitig wird eine Erweiterung für den Endpunkt Geschlechterverhältnis der Nachkommen validiert (OECD 2008c). In einem Interlaborvergleich wurden als Referenzsubstanzen 3,5-Dichlorophenol und Pyriproxifen eingesetzt, wovon nur in 5 von 10 Laboratorien die Validitätskriterien für Pyriproxifen und in 7 von 8 Laboratorien die Validitätskrtiterien für 3,5-Dichlorophenol erreicht wurden. Insgesamt kann aufgrund der vorhandenen Information noch nicht ausgesagt werden, ob die Erweiterung um das Geschlechterverhältnis der Nachkommen sich als empfindlicher erweisen wird (OECD 2008c). Allerdings liegt der angegebene Arbeitsaufwand für den Daphnia-magna-Reproduktionstest auch ohne Erweiterung schon höher als der Reproduktionstest mit Potamopyrgus antipodarum (siehe Abb. 6). Im Gegensatz zum Daphnien-Reproduktionstest reagieren Schnecken auf vielfältige östrogene und androgene Substanzen sensitiv, die auch in Vertebraten ein endokrines Potenzial besitzen (Duft et al. 2007; siehe auch Abb. 9). Es ist abhängig von der Wahl des Schutzzieles, welches Testverfahren bevorzugt werden sollte. Da es sich bei Potamopyrgus antipodarum (neuseeländische Zwergdeckelschnecke) um einen nichtheimischen Vertreter der Schnecken handelt, sollten Laborexperimente gegenüber Feldexperimenten bevorzugt werden, um mögliche Faunenverfälschungen zu vermeiden. Bei der langen Versuchszeit und den Überlagerungsmöglichkeiten mit dem Reproduktionszyklus (Frühjahr und Herbst) könnten wahrscheinlich auch nur wenige Proben im Jahr untersucht werden. Aufgrund des Artenreichtums, der breiten Sensitivität und der nachgewiesenen vielseitigen Anwendbarkeit für ein Umweltmonitoring wären Schneckentests aus ökotoxikologischer Sicht zu empfehlen, sofern sich diese Verfahren auch als ausreichend valide und übertragbar erweisen.

\subsection{Funktionsprinzip der modularen Testpalette}

Durch Schadstoffe in Umweltproben können vielfältig gerichtete Wirkungen auftreten, die einander überlagern und berücksichtigt werden müssen. Die modulare Testpalette versucht dabei, die unterschiedlichen Wirkmechanismen der endokrinen Disruption und reproduktionstoxische, bzw. embryotoxische Effekte in verschiedenen In-vitro- und In-vivo-Modulen gemeinsam zu erfassen. Durch die kombinierte Anwendung der Module (siehe Abb. 12) sollte es möglich sein, von den elementaren biochemischen Wirkmechanismen bis zu organismischen Effekten auch populationsrelevante Wirkpotenziale nachzuweisen.

Auf der In-vitro-Seite können einige empfindliche YES/ YAS-Systeme und die verschiedenen Calux-Systeme als zelluläre Verfahren eine agonistische und antagonistische 
Rezeptorbindung an verschiedenen Hormonrezeptoren erfassen. Ebenfalls kann der H295R-Steroidgenesis-Assay Modulationen der Steroidgenese und eventuell auch der Aromataseaktivität nachweisen und ergänzt damit gut die vielfältigen Detektionsmöglichkeiten für rezeptorvermittelte Wirkungen.

Auf der In-vivo-Seite kann eine populationsrelevante Reproduktionstoxizität sowohl durch hormonaktive Wirkungen als auch durch allgemeintoxische Wirkungen verursacht werden. Daher wurden die Reproduktionstests mit Potampyrgus antipodarum und Daphnia magna empfohlen, da diese derzeit verfügbar sind.

Sollten zu starke toxische Effekte eine Anwendung der empfohlenen Module behindern (hier muss dann in der Regel in Verdünnungen getestet werden, die unterhalb der (Zyto)toxizität liegen), so kann in vitro ein biochemischer Rezeptorbindungassay integrativ agonistische und antagonistische Rezeptorbindungen erfassen. Starke toxische bzw. embryotoxische Wirkungen können z.B. relativ schnell durch den Fischeitest identifiziert werden, oder man benutzt einen nicht akuten Invertebratentest, der auch verzögerte und Langzeit-Effekte anzeigen kann. Da der Stellenwert der thyroidalen Modulation an einer endokrinen Disruption nicht zu bestimmen ist, könnte man optional den XEMA zum Nachweis thyroidaler Effekte oder Calux-Verfahren als Screeningtests benutzen. Durch die internationalen Bestrebungen Vertebratentests zu minimieren ist die Entwicklung sensitiver Invertebratentests zu fördern und anzuregen.

In-vitro-Tests können eingesetzt werden um akute Qualitätsziele zu überprüfen, hingegen können die In-vivo-Tests dazu dienen, auch chronische Qualitätsziele zu überprüfen, beispielsweise wenn an bestimmten Einleitungsstellen hohe Belastungen organischer Mikroverunreinigungen gefunden werden.

\section{Schlussfolgerungen und Ausblick}

Im Forschungsbericht zur Gewässerrelevanz endokriner Stoffe und Arzneimittel (Moltmann et al. 2007) konnte anhand aquatisch relevanter Schadstoffe mit In-vivo-Tests gezeigt werden, dass endokrine Endpunkte (bei 31 von 71 untersuchten Stoffen) empfindlicher sein können als allgemeine ökotoxikologische Endpunkte (z.B. Mortalität, Wachstum usw.). Eine Einschätzung, für welche Substanzen und in welchem Ausmaß dies in der Umwelt zutrifft, ist bei der Vielfalt der Umweltchemikalien und derer gegenseitigen Beeinflussungsmöglichkeiten nicht möglich. Daher sollten hormonaktive und allgemeintoxische Effekte integrativ durch ökotoxikologische Biotestpaletten erfasst und differenziert werden.

Bei der Vielfältigkeit der endokrinen Wirkmechanismen bedarf es einer modularen Kombination von In-vivo- und Invitro-Verfahren in einer modularen Testpalette, um auch die fließenden Übergänge von hormonaktiven Wirkungen bis zu einer endokrinen Disruption und reproduktionstoxischen Effekten erfassen und differenzieren zu können. Geforderte Kriterien wie Nachvollziehbarkeit, Relevanz, Reproduzierbarkeit und Plausibilität müssen bei einem geeigneten ökotoxikologischen Verfahren nicht ausgeschlossen werden, doch bedarf es valider und übertragbarer Methoden für eine Bewertung. Daher war neben einer Umweltprobentauglichkeit die Validierung und die Verbreitung der Testverfahren, zumindest aber eine gute Möglichkeit zur Standardisierbarkeit, ein wichtiges Kriterium bei deren Auswahl.

Der Fischeitest ist mehrfach genormt, XEMA und H295R Steroidgenesis Assay sind sehr weit im OECD-Validierungsprozess fortgeschritten. Der Reproduktionstest mit Potamopyrgus antipodarum hat sich bereits für ein Umweltmonitoring bewährt (Schulte-Oehlmann et al. 2001) und wird wahrscheinlich von der OECD validiert werden. Für verschiedene YES/YAS-Systeme bestehen jahrelange Erfahrungswerte für Umweltprobenbewertungen, die ER/AR-Calux-Systeme sind ebenfalls in einer frühen Validierungsphase der OECD, auch bei den molekularen Rezeptorbindungsassays laufen derzeitig mehrere Validierungen der OECD (siehe Tabelle 4). Das vorgestellte modulare System erlaubt einen Austausch der Testmodule nach dem sich kontinuierlich entwickelnden Stand der Technik, ohne Neuentwicklungen oder Gegegebenheiten zu einer veränderten Gesetzeslage (z.B. Vermeidung von Vertebratentests) auszuschließen.

Die Testpalette ermöglicht eine umfassende wirkungsbezogene Risikobewertung für die aquatische Umwelt, wobei der Testumfang auf die Ansprüche der Anwender angepasst werden kann. Es können fortpflanzungsrelevante Wirkungen an Invertebraten, Amphibien und Fischen, ebenso wie wirkmechanistische Ansätze der östrogenen und androgenen Rezeptorbindung, der Steroidgenese, eventuell sogar der Aromatasemodulation erfasst werden. Es stellt einen möglichen wirkungsbezogenen Lösungsweg für eine Risikobewertung der endokrinen Disruption und hormonaktiven Substanzen in der Umwelt dar. Sollte ein Teil aus dieser Testpalette für Umweltanwendungen genormt und anschließend flächendeckend für ein Umweltmonitoring eingesetzt werden, so wäre eine Grundlage gegeben eine Risikobeurteilung und ein Risikomanagement für die endokrine Disruption einzuleiten.

Danksagung Ein besonderer Dank gilt den Anwendern und Entwicklern, die sich bereit erklärt haben im Rahmen der Kriterienabfrage Daten zu den Testverfahren bereitzustellen und zu belegen. Ebenfalls möchten wir den hilfsbereiten Ansprechpartnern der Umweltämter Herrn Dr. Pluta und Herrn Dr. Stolzenberg (UBA) sowie Herrn Dr. Schärer und Herrn Dr. Studer (BAFU) für ihre Unterstützung danken.

Open Access Dieser Artikel wird zu den Bedingungen der „Creative Commons Attribution Noncommercial License“ zur Verfügung gestellt. Damit ist eine nichtkommerzielle Nutzung, Verbreitung und Vervielfältigung erlaubt, sofern die Autoren des Artikels und die genaue Quelle angegeben sind. 


\section{Literatur}

2000/60/EG WRRL (2000) Richtlinie 2000/60/EG des Europäischen Parlamentes und des Rates vom 23. Oktober 2000 zur Schaffung eines Ordnungsrahmens für Maßnahmen der Gemeinschaft im Bereich der Wasserpolitik. Amtsblatt Nr. L327 vom 22. 12. 2000 S 1-73

Ackermann GE, Brombacher E, Fent K (2002a) Development of a fish reporter gene system for the assessment of estrogenic compounds and sewage treatment plant effluents. Environ Toxicol Chem 21:1864-1875

Ackermann G, Schwaiger J, Negele RD, Fent K (2002b) Effect of long-term nonylphenol exposure on gonadal development and biomarkers of estrogenicity in juvenile rainbow trout (Oncorhynchus mykiss). Aquat Toxicol 60:203-22

Andersen HR, Andersson AM, Arnold SF, Autrup, Barfoed M, Beresford NA, Bjerregaard P, Christiansen LB, Gissel B, Hummel R, Jorgensen EB, Koorsgaard B, Le GuevelR, Leffers H, Mclachlan J, Moller A, Nielsen JB, Olea N, Oles-Karasko, Pakdel F, Pedersen KL, Perez P, Skakkeboek NE, Sonnenschein C, Soto AM, Sumpter JP, Thorpe SM, Grandjean P (1999) Comparison of short-term estrogenicity tests for identification of hormone disrupring chemicals. Environ Health Perspect 107:89-108

Andersen HR, Wollenberger L, Halling-Sorensen B, Kusk KO (2001) Development of copepod nauplii to copepodites - a parameter for chronic toxicity including endocrine disruption. Environ Toxicol Chem 20:2821-2829

Andersen HR, Vinggaard, Rasmussen TH, Gjermandsen IM, Bonefeld-Jorgensen EC (2002) Effects of currently used pesticides in assays for estrogenicity, androgenicity, and aromatase activity in vitro. Toxicol Appl Pharmacol 179:1-12

Ankley G, Mihaich E, Stahl R, Tillitt D, Colborn T, McMaster S, Miller R, Bantle J, Campbell P, Denslow N, Dickerson R, Folmar L, Fry M, Giesy J, Gray E, Guiney P, Hutchinson T, Kennedy S, Kramer V, LeBlanc G, Mayes M, Nimrod A, Patino R, Peterson R, Purdy R, Ringer R, Thomas P, Touart L, van der Kraak G, Zacharewski T (1997) Overview of a workshop on screening methods for detecting potential (anti-) estrogenic/androgenic chemicals in wildlife. Environ Toxicol Chem 17(1):68-87, SETAC, USA

Ankley GT, Jensen KM, Kahl MD, Korte JJ, Makynen EA (2001) Description and Evaluation of a short-term reproduction test with the Fathead Minnow (Pimephales promelas). Environ Toxicol Chem 20:1276-1290

Baatrup E, Junge M (2001) Antiandrogenic pesticides disrupt sexual characteristics in the adult male guppy (Poecilia reticulata). Environ Health Perspect 109:1063-1070

Ballegooy C (2008) Endokrine Wirkungen (anti)androgener Substanzen bei der Ploetze (Rutilus rutilus). Dissertation der Mathematischen-Naturwissenschaftlichen Fakultaet I der Humboldt-Universitaet zu Berlin, BRD

Barata C, Porte C, Baird D (2004) Experimental designs to assess endocrine disrupting effects in invertebrates a review. Ecotoxicol 13:511-517

Bätscher R, Studer C, Fent K (1999) Stoffe mit endokriner Wirkung in der Umwelt. In: Eidg. Anstalt für Wasserversorgung, Abwasserreinigung und Gewässerschutz (EAWAG) und dem Bundesamt für Umwelt, Wald und Landschaft (BUWAL) (Hrsg) Schriftenreihe Umwelt Nr. 308

BKH (2000) European Commission DG ENV. Towards the establishment of a priority list of substances for further evaluation of their role in endocrine disruption- preparation of a candidate list of substances as a basis for priority setting. Final Report. BKH Consulting Engineers, Delft, The Netherlands in association with TNO Nutrition and Food Research, Zeist, The Netherlands. Project: M0355008/1786Q/10/11/00
Braunbeck T (1993) Entwicklung von Biotestverfahren mit Zellkulturen aus Fischen und Mollusken zum Nachweis letaler und subletaler Schäden von Organismen durch Umweltschadstoffe im Wasser. PAÖ 7: 537-559

Charles GD (2004) In vitro models in endocrine disruptor screening. ILAR J 45(4):494-501

Cheshenko K, Pakdel F, Segner H, Kah O, Eggen RI (2008) Interference of endocrine disrupting chemicals with aromatase CYP19 expression or activity, and consequences for reproduction of teleost fish. Gen Comp Endocrinol 155(1):31-62

Coe TS, Hamilton PB, Hodgson D, Paull GC, Stevens JR, Sumner K, Tyler CR (2008) An environmental estrogen alters reproductive hierarchies, disrupting sexual selection in group-spawning fish. Environ Sci Technol 42:5020-5025

COM (99)706 (1999) Community Strategy for Endocrine Disrupters COM (99)706; COMMUNICATION FROM THE COMMISSION TO THE COUNCILAND THE EUROPEAN PARLIAMENT (1999), http://ec.europa.eu/environment/docum/99706sm.htm

$\operatorname{COM}(2006) 397$ final (2006) Proposal for a Directive of the European Parliament and of the Council on environmental standards in the field of water policy and amending Directive 2000/60/EC. Commission of the European Communities, Brussels, 17. 7.2006. $\operatorname{COM}(2006) 397$ final. 2006/0129 (COD)

Commission of the European Communities (1996): Technical guidance document in support of directive 93/67/EEC on risk assessment for new notified substances and commission regulation 1488/94, risk assessment for exsiting substances. Office for Official Publications of the European Communities, Luxembourg, Belgium

Damstra T, Barlow S, Bergman A, Kavlock R, van der Kraak G (2003) Global assessment of the state of the science of endocrine disruptors. World Health Organisation/PCS/EDC/02.2

Depledge MH, Fossi MC (1998) The role of biomarkers in environmental assessment: 2. invertebrates. Ecotoxicology 3:112-129

Desbrow C, Routledge EJ, Brighty GC, Sumpter JP Waldcock M (1998) Identification of estrogenic chemicals in STW effluent 1. Chemical Fractionation and in vitro biological screening. Environ Sci Technol 11:1549-1558

Duft M, Schmitt C, Bachmann J, Brandelic C, Schulte-Oehlmann U, Oehlmann J (2007): Prosobranch snails as test organisms for the assessment of endocrine active chemicals-an overview and a guideline proposal for a reproduction test with the freshwater mudsnail Potamopyrgus antipodarum. Ecotoxicology 16:169-182. DOI 10.1007/s10646-006-0106-0

Dutta P, Hill K, Datskos PG, Sepaniak MJ (2007) Development of a nanomechanical biosensor for analysis of endocrine disrupting chemicals. The Royal Society of Chemistry. Lab Chip 7:1184-1191

EC (European Commission) (1997) (DG XII - Environment and Climate Research Programme). European Workshop on the Impact of Endocrine Disruptors on human Health and Wildlife. Report of Proceedings of a Workshop 2-4 December 1996, Weybridge, UK. Commission of the European Community, Brussels; Report EUR 17549

Eggen R (2008) Rolle der Östrogene in der Organogenese In: Eawag (Hrsg) Zebrabärblinge - Sensoren in der Ökotoxikologie. Eawag News 64d, Eawag das Wasserforschungsinstitut des ETH-Bereichs

Eggins BR (2002) Chemical Sensors and Biosensors. Analytical Techniques in the Sciences. 2. Aufl, Wiley

Escher B, Vermeirssen E (2008) Mikroverunreinigungen in schweizerischen Fliessgewässern: Konzepte zur Beurteilung von Mischungen in der Ableitung von toxikologisch begründeten Qualitätskriterien für östrogenartig wirkende Stoffe. Eawag Schlussbereicht zuhanden des BAFU, 30. Oktober 2008

Fechner P, Pröll F, Carlquist M, Proll G (2008) An advanced biosensor for the prediction of estrogenic effects of endocrine-disrupting chemicals on the estrogen receptor alpha. Anal Bioanal Chem DOI 10.1007/s00216-008-2480-3 
Fent K (1995) Endokrin wirksame Stoffe in der Umwelt: Erkenntnisstand und Probleme. In: Umweltchemikalien mit endokriner Wirkung. UBA-Texte 65/95 ISSN 0722-186X

Fent K (2000) Hormonaktive Stoffe in Gewässern: Auch eine Gefahr fürs Trinkwasser? Gesellschaft für Lebensmittelhygiene. Mitt Lebensm Hyg 9:11-25

Fine T, Leskinen P, Isobe T, Shiraishi H, Morita M, Marks RS, Virta $\mathrm{M}$ (2006) Luminescent yeast cells entrapped in hydrogels for estrogenic endocrine disrupting chemical biodetection. Biosens Bioelectron 21:2263-2269

Folmar LC, Hemmer MJ, Denslow ND, Kroll K, Chen J, Cheek, Richman H, Meredith H, Grau GE (2002) A comparison of the estrogenic potencies of estradiol, ethinylestradiol, diethystilbestrol, nonylphenol and methoxychlor in vivo und in vitro. Aquat Toxicol 60:101-110

FNSNF (2008a) Nationales Forschungsprogramm „Hormonaktive Stoffe". Öffentlicher Schlussbericht. Schweizerischer Nationalfonds

FNSNF (2008b) Konsensplattform „Hormonaktive Stoffe in Abwassern und Gewässern" Schlussdokument. Nationales Forschungsprogramm „Hormonaktive Stoffe“. http://www.nrp50.ch/finalproducts/final-reports-consensus-plattforms.html

Frische T, Faust M, Meyer W, Backhaus T (2009): Toxic masking and synergistic modulation of the estrogenic activity of chemical mixtures in a yeast estrogen screen (YES). Environ Sci Pollut Res DOI 10.1007/s11356-009-0184-7

Fröhlicher M (2008) Zebrabärblinge ohne Oestrogenrezeptoren. In: Eawag (Hrsg) Zebrabärblinge - Sensoren in der Ökotoxikologie. Eawag News 64d, Eawag das Wasserforschungsinstitut des ETHBereichs

Gagné F, Blaise C, Pellerin J (2005) Altered exoskeleton composition and vitellogenesis in the crustacean Gammarus sp. collected at polluted sites in the Saguenay Fjord, Quebec, Canada. Environ Res 98:89-99

Garcia-Reyero N, Grau E, Castillo M, Lopez de Alda M J, Barcelo D, Pina B (2001) Monitoring of endocrine disruptors in surface waters by the yeast recombinant assay. Environ Toxicol Chem 20:1152-1158

Gerhardt A (1999) Biomonitoring of polluted waters. Trans Tech Publications, Zürich. $301 \mathrm{pp}$

Gerhardt A (2007) Behavioural ecotoxicology - prospects and limitations. HERA 13(3):481-492

Global Water Research Coalition (2006) In Vitro Bioassays to Detect Estrogenic Activity in Environmental Waters. Literature Review

Gracia T, Jones PD, Higley EB, Hilscherova K, Newsted JL, Murphy MB, Chan AKY, Zhang X, Hecker M, Lam PKS, Wu RSS, Giesy JP (2008) Modulation of steroidgenesis by coastal waters and sewage effluents of Hong Kong, China using the H295R assay. Environ Sci Pollut Res, DOI 10.1007/s11356-008-0011-6

Gray L E, Ostby J, Wilson V, Lambright C, Bobseine K, Hartig P, Hotchkiss A, Wolf C, Furr J, Price M, Parks L, Cooper RL, Stoker TE, Laws SC, Degitz SJ, Jensen KM, Kahl MD, Korte JJ, Makynen EA, Tietge JE, Ankley GT (2002) Xenoendocrine disrupters-tiered screening and testing Filling key data gaps. Toxicol 181-182:371-382

Gross MY, Maycock DS, Thorndyke MC, Morrit D, Crane M (2001) Abnormalities in sexual development of the amphipod Gammarus pulex (L.) found below sewage treatment works. Environ Toxicol Chem 20:1792-1797

Grund et al. (in Vorbereitung)

Gutendorf B, Westendorf J (2001) Comparison of an array of in vitro assays for the assessment of the estrogenic potential of natural and synthetic estrogens, phytoestrogens and xenoestrogens. Toxicol 166:79-89

Gülden M, Turan A, Seibert H (1997) Substanzen mit endokriner Wirkung in Oberflächengewässern. UBA- Texte 46/97, Umweltbundesamt Berlin
Hansen P-D, Dizer H, Hock B, Marx A, Sherry J, McMaster M, Blaise C (1998) Vitellogenin a biomarker for endocrine disruptors. Trends Anal Chem 17(4):48-45

Hansen P-D (2000) Erfassung und Bewertung „unerwünschter Wirkungen" mit Biotests und Biosensoren. In: Schriftenreihe Wasserforschung, No.6: Chemische Stressfaktoren in aquatischen aquatischen Systemen, Herausgeber: Wasserforschung e. V. interdisziplinärer Forschungsverband

Harries JE, Runnalls T, Hill E, Harris CA, Maddix S, Sumpter JP, und Tyler CR (2000) Development of a Reproductive Performance Test for Endocrine Disrupting Chemicals Using Pair-Breeding Fathead Minnows (Pimephales promelas). Environ Sci Technol 34:3003-3011

Hartig PC, Cardon MC, Blystone CR, Gray LE Jr, Wilson VS (2008) High throughput adjustable 96-well plate assay for androgen receptor binding: a practical approach for EDC screening using the chimpanzee AR. Toxicol Lett 181:126-131

Hecker M, Hollert H, Cooper R, Vinggard A-M, Akahori Y, Murphy M, Nellemann C, Higley E, Newsted, Wu R, Lam P, Laskey J, Buckalew A, Grund S, Nakai M, Timm G, Giesy J (2007a) The OECD Validation Program of the H295R Steroidgenesis Assay for the Identification of In vitro Inhibitors or Inducers of Testosterone and Estradiol Production. Phase 2: Inter Laboratory Pre- Validation Studies. Env Sci Pollut Res 14, Special Issue, 23-30

Hecker M, Timm G, Vinggaard A-M, Nelleman C, Akahori Y, Cooper R, Hollert H, Han S-Y, Murphy MB, Newsted JL, Giesy JP (2007b) Validation of a H295R Cell Line Screening Test to Evaluate toxicant-Induced Effects on Steroidgenesis. Vortrag bei der korenaischen Food and Drug Administration im Oktober 2007

Highley et al. (in Vorbereitung)

Hock B, Seifert M (1998) Monitoring-Strategien für östrogene Wirkstoffe. Bioforum 11:690-696.

Hollert H, Dürr M, Holtey-Weber R, Islinger M, Brack W, Färber H, Erdinger L, Braunbeck T (2005) Endocrine Disruption of Water and Sediment Extracts in a Non-Radioactive Dot Blot/RNAse Protection-Assay Using Isolated Hepatocytes of Rainbow Trout. Environ Sci Pollut Res 12(6):347-360

Hutchinson TH, Ankley GT, Segner H, Tyler CR (2006) Screening an Testing for Endocrine Disruption in Fish-Biomarkers As "Signposts", Not "Traffic Lights" in Risk Assessment. Environ Health Perspect 114:106-114

ISO/FDIS 15088 (2007) Water quality-Determination of the acute toxicity of waste water to zebrafish eggs (Danio rerio)

Jobling S, Sumpter JP (1993) Detergent components in sewage effluent are weakly oestrogenic to fish: An in vitro study using rainbow trout (Oncorhynchus mykiss) hepatocytes. Aquat Toxicol $27: 361-372$

Kammann U, Vobach M, Wosniok W, Schäffer A, Telscher A (2009) Acute toxicity of 353-nonylphenol and its metabolites for zebrafish embryos. Environ Sci Pollut Res 16:227-231, DOI 10.1007/ s11356-008-0097-x

Kang IJ, Yokota H, Oshima Y, Tsuruda Y, Yamaguchi T, Maeda M, Imada N, Tadokoro H, Honjo T (2002): Effect of 17- $\beta$-estradiol on the reproduction of Japanese medaka (Oryzias latipes). Chemosphere 47:71-80

Kase R (2004): Salinitätseinflüsse auf suborganismische Testsysteme zur Erfassung von ökotoxikologischen Sedimentwirkungen. Diplomarbeit, angefertigt an der TU Berlin am Institut für Ökologie im Fachgebiet Ökotoxikologie

Kase R, Hansen P-D, Fischer B, Heininger P, Manz W, Reifferscheid G (2008) Integral Assessment of Estrogenic Potenitals of SedimentAssociated-Samples. Part I: The Influence of salinity on the in vitro tests ELRA, E-screen and YES. Env Sci Pollut Res 15(ESPR 1): 75-83 (2008) http://dx.doi.org/10.1065/espr207.6.429 
Kase R, Hansen P-D, Fischer B, Heininger P, Manz W, Reifferscheid G (2008) Integral Assessment of Estrogenic Potentials in Sediment-Associated SamplesPart II: Study of estrogen and anti-estrogen receptor binding potentials of sediment-associated chemicals under different salinity conditions using the salinityadapted enzyme linked receptor assay. Env Sci Pollut Res http:// dx.doi.org/10.1007/s11356-008-0060-x

Katsiadaki I, Scott A P, Hurst M R, Matthiessen P, Mayer I (2002) Detection of environmental androgens: A novel method, based on an enzyme-linked immunosorbentassay of spiggin, the stickleback (Gasterosteus aculeatus) glue protein. Environ Toxicol Chem 21:1946-1954

Kinnberg K (2003) Evaluation of in vitro assays for determination of estrogenic activity in the environment. Working Report No. 43, Danish Environmental Protection Agency

Körner W, Hanf V, Schuller W, Zwirner M, Hagenmaier H (1997) Entwicklung und praktische Erprobung eines einfachen Screening-Systems für estrogenartig wirkende Umweltchemikalien. In: 6. Statuskolloquium des Projekt „Umwelt und Gesundheit“, Herausgeber: Forschungszentrum Karlsruhe

Kloas W (2002) Amphibians as a model for the study of endocrine disrupters. Int Rev Cytol 216:1-57

Kloas W, Lutz I, Einspanier R (1999) Amphibians as a model to study endocrine disruptors: II. Estrogenic activity of environmental chemicals in vitro und in vivo. Sci Total Environ 225:59-68

Knacker T, Schäfers C, Teigeler M, Braunbeck T (2007) Charakterisierung endokrin vermittelter Wirkungen in Fischen: Relevante Parameter für die Entwicklung einer neuen OECD-Testmethode und die Anwendung in der gesetzlichen Umweltrisikobewertung. Forschungsprojekt des Umweltbundesamtes FKZ 20667470

Krebs F (2001) Ökotoxikologische Baggergutuntersuchung, Baggergutklassifizierung und Handhabungskatagorien für Baggergut. In: Untersuchung und Bewertung von Sedimenten, Hrsg.: Calmano W, Springer-Verlag, Berlin Heidelberg

Kunz PY, Fent K (2006) Estrogenic activity of UV filter mixtures. Toxicol Appl Pharmacol 217:86-99

Kunz PY, Gries T, Fent K (2006a) The ultraviolet filter 3-benzylidene camphor adversely affects reproduction in fathead minnow (Pimephales promelas). Toxicol Sci 93:311-321

Kunz PY, Galicia HF, Fent K (2006b) Comparison of In Vitro and In Vivo Estrogenic Activity of UV Filters in Fish. Toxicol Sci 90(2):349-361

Kunz PY, Fent K (2009) Estrogenic activity of ternary UV filter mixtures in fish (Pimephales promelas) - an analysis with nonlinear isobolograms. Toxicol Appl Pharmacol 234(1):77-88

Kunz PY, Kienle C, Gerhardt A (2009, akzeptiert) Gammarus spp. in aquatic ecotoxicology and water quality assessment: towards integrated multilevel tests. Rev Environ Contam Toxicol

Kusk KO, Wollenberger L (2007) Towards an internationally harmonized test method for reproductive and developmental effects of endocrine disrupters in marine copepods. Ecotoxicol 16(1): $183-95$

Länge R, Caspers N, Ensenbach U, Pallapies D, Zok S (2006) Kriterien zur Bewertung der Qualität und Validität von toxikologischen und ökotoxikologischen Studien für regulatorische Fragestellungen. UWSF-Z Umweltchem Ökotox 18:49-54

Larkin P, Villeneuve DL, Knoebl I, Miracle AL, Carter BJ, Liu L, Denslow ND, Ankley GT (2007) Development and validation of a 2000-Gene Microarray for the Fathead Minnow (Pimephales promelas). Environ Tox Chem 26(7):1497-1506

Lattier DL, Reddy TV, Gordon DA, Lazorchak JM, Smith ME, Williams DE, Wiechman B, Flick RW, Miracle AL, Toth GP (2002) $17-\alpha$-ethinylestradiol-induced vitellogenin gene transcription qunatified in livers of adult males, larvae, and gills of farhead minnows (Pimephales promelas). Environ Toxicol Chem 21(11):2385-2395
Legler J, Dennekamp M, Vethaak D, Brouwer A, Koeman JH, van der Burg B, Murk AJ (2002) Detection of estrogenic activity in sediment-associated compounds using in vitro reporter gene assays. Science Total Environ 293:69-83

Leon A, Wu P-S, Hall LC, Johnson ML, The SJ (2008) Global gene expression profiling of androgen disruption in Qurt Strain Medaka. Environ Sci Technol 42(3):962-969, DOI:10.1021/es071785c

Leusch FDL, van den Heuvel MR, Chapman HF, Gooneratne SR, Eriksson AME, Tremblay LA (2006) Development of methods for extraction and in vitro quantification of estrogenic an androgenic activity of wastewter samples. Comp Biochem Physiol 143:117-126

Leusch F (2008) Tools to Detect Estrogenic Activity in Environmental Waters. Global Water Research Coalition 2008

Li C-R, Lee S-H, Kim S-S, Kim A, Lee KW, Lu M, Kim H-E, Kwak I-J, Lee Y-J, Kim D-K, Lee J-S, Kang S-W, Huh M-D, Chung K-H, Park J-S (2008) Environmental estrogenic effects and gonadal development in wild goldfish (Carassius auratus). Environ Monit Assess, DOI 10.1007/s10661-008-0238-1

Manz W, Krebs F, Schipper CA, den Besten PJ (2007) Dutch-German Exchange on Dredged Material: Status of ecotoxicological assessment of sediment and dredged material in Germany and The Netherlands with a short description of the situation in Belgium, France, and Great Britain. Federal Institute of Hydrology (BfG), Ministry of Transport, Public Works an Water Management (RIKZ), Institute for Inland Water Management and Waste Water Treatment (RIZA)

Martyniuk CJ, Gerrie ER, Popesku JT, Ekker M, Trudeau VL (2007) Microarray analysis in the zebrafish (Danio rerio) liver and telencephalon after exposure to low concentration of 17alpha-ethinylestradiol. Aquatic Toxicology 84:38-49

Matthiessen P (2000): Is Endocrine Disruption a Significant Ecological Issue? Ecotoxicol 9:21-24

Metcalfe CD, Metcalfe TL, Kiparissis Y, Koenig BG, Khan C, Hughes RJ, Croley TR, March RE, Potter T (2001) Estrogenic Potency of chemicals detected in sewage treatment plant effluents as determined by in vivo assay with Japanese Medaka (Oryzias latipes). Environ Toxicol Chem 20:297-308

Michelini E, Leskinen P, Virta M, Karp M, Roda A (2005) A new recombinant cell-based bioluminescent assay for sensitive androgen like compound detection. Bios Bioelectron 20:2261-2267

Miles-Richardson SR, Pierens SL, Nichols KM, Kramer VJ, Snyder EM, Snyder SA, Render JA, Fitzgerald SD and Giesy JP (1999) Effects of waterborne exposure to 4-nonylphenol and nonylphenol ethoxylate on secondary sex characteristics and gonads of fathead minnows (Pimephales promelas). Environ Res Sect A $80: 122-137$

Moltmann JF, Liebig M, Knacker T, Keller M, Scheurer M, Ternes T (2007) Gewässerrelevanz endokriner Stoffe und Arzneimittel. Abschlussbericht des F+E-Vorhaben-FKZ 20524205 des deutschen Umweltbundesamtes

Muncke J, Junghans M, Eggen RIL (2006) Testing Estrogenicity of known an novel (xeno-)estrogens im the MolDarT using developing zebrafish (Danio rerio). Published online in Wiley Interscience, DOI 10.1002/tox.20255

Muncke J (2008) Der MolDarT-ein neuer Toxizitätstest. In: Eawag (Hrsg) Zebrabärblinge - Sensoren in der Ökotoxikologie. Eawag News 64d, Eawag das Wasserforschungsinstitut des ETHBereichs

Murk AJ, Legler J, van Lipzig MMH, Meerman JHN, Belfroid AC, Spenkelink A, van der Burg B, Rijs GBJ, Vethaak D (2002) Detection of estrogenic potency in wastewater and surface water with three in vitro bioassays. Environ Toxicol Chem 21:16-23

Murk AJ (2009) Effects of endocrine disruptors on early development and metamorphosis. Vortrag am 12.1.2009 am Oekotoxzentrum der Eawag, Schweiz 
Navas JM, Segner H (2006) Vitellogenin synthesis in primary cultures of fish liver cells as endpoint for in vitro screening of the (anti) estrogenic activity of chemical substances. Aquat Toxicol 80:1-22

Nelson J, Bishay F, van Roodselaar A., Ikonomou M, Law FC (2007) The use of in vitro bioassays to quantify endocrine disrupting chemicals in municipial wastewater treatment plant effluents. Sci Total Environ 374:80-90

Nishi Y, Yanase T, Mu Y-M, Oba K, Ichino I, Saito M, Nomura M, Mukasa C, Okabe T, Goto K, Takayanagi R, Yoshiko K, Haji M, Nawata H (2001) Establishment and Characterization of a Steroidogenic Human Granulosa-Like Tumor Cell Line, KGN, That Expresses Functional Follicle-Stimulating Hormone Receptor. Endocrinol 142(1):437-445

Nishimura N, Fukazawa Y, Uchiyama H, Iguchi T (1997) Effects of estrogenic hormones on early development of Xenopus laevis. J Exp Zool 278:221-233

OECD Environment, Health and Safety Division Test Guidelines Programme (2005) The role and current activities of OECD on validation of testing of endocrine disrupting chemicals. http:// ec.europa.eu/research/endocrine/pdf/nov2005/oecd_en.pdf

OECD (2006a) Environmental Health and Safety Publications. Series on testing and Assessment No. 60 Report of the initial work towards the validation of the 21-day Fish Screening Assay for the detection of endocrine active substances. Environment Directorate, Organisation for economic Co-operation and Development, Paris 2006

OECD (2006b) Environment Directorate No. 55: Detailed review paper on aquatic arthropods in life cycle toxicity tests with an emphasis on developmental, reproductive and endocrine disruptive effects. Series on testing and assessment No. 55. ENV/JM/ Mono(2006)22, JT03212400

OECD (2008a) Environment Directorate No. 94: Report of the validation peer review for the 21 day Fish Screening assay and agreement of the working group of the national coordinators of the test guidelines programme on the follow-up of this report. ENV/JM/ Mono(2008)21, JT03249201

OECD (2008b) Environment Directorate No. 99: Comparison between OECD Test Guidelines and ISO standards in areas of ecotoxicology and health effects. Series on testings and assessment number 99. Joint meeting of the chemicals Commiteee and the working party on chemicals, Pesticides and Biotechnology. ENV/JM/ Mono(2008)28, JT03255859

OECD (2008c) Environment, Health and Safety Publications No. 93: Report of the validation of an enhancement of OECD TG 211: Daphnia magna reproduction test. Series on testing and assessment No. 93. ENV/JM/Mono(2008)20

OECD (2009, inVorbereitung) Receptor Binding Assay and Reporter Gene Assay in Fish

Oikawa S, Matsumoto M (2003) Relevant activities for risk managment of endocrine disruptors in Japanes government agencies. Pure Appl Chem 75:2609-2611

Oehlmann J, Schulte-Oehlmann U (2003) Endocrine disruption in invertebrates. Pure Appl Chem 75:2207-2218

Oehlmann J, Di Bendetto P, Tillmann M, Duft M, Oetken Matthias, Schulte-Oehlmann U (2007) Endocrine disruption in prosobranch molluscs: evidence and ecological relevance. Ecotoxicol 16(1):29-43, DOI 10.1007/s10646-006-0109-x

Pawlowski S, Ternes T, Bonerz M, Kluczka T, van der Burg B, Nau H, Erdinger L, Braunbeck T (2003) Combined in Situ and in Vitro Assessment of the Estrogenic Avcitivity of Sewage and Surface Water Samples. Toxicol Sci 75:57-65, DOI:10.1093/toxsci/ $\operatorname{kfg} 162$

Pawlowski S, Sauer A, Shears JA, Tyler CR, Braunbeck T (2004) Androgenic and estrogenic effects of the synthetic androgen $17 \alpha$-methyltestosterone on sexual development and reproductive performance in the fathead minnow (Pimephales promelas) de- termined using the gonadal recrudescence assay. Aquat Toxicol 68:277-291

Petit F, Valotaire Y, Pakdel F (1995) Differential functional activities of rainbow trout nad human estrogen receptors expressed in the yeast Saccharomyces cerevisiae. Eur J Biochem 233:584-592

Pluta HJ (2008a) Nachhaltiger Gewässerschutz - biologische Wirkungstests im Wasserhaushalts- und Abwasserabgabengesetz: eine Erfolgsgeschichte. Symposium am 26.2.2008 in Koblenz an der Bundesanstalt für Gewässerkunde: ,Verfahren der ökotoxikologischen (Risiko-) Bewertung in der Umweltsicherung“"

Pluta HJ (2008b) Benefit from standardization, regulatory and scientific requirements, procedures and participations. Vortrag an der Bundesanstalt für Gewässerkunde in Koblenz am 13-14. November zum Thema: Sediment Contact Tests Reference conditions, control sediments, toxicity tresholds

Preston BL, Snell TW, Robertson TL, Dingmann, BJ (2001) Use of freshwater rotifer Brachionus calyciflorus in screening assay for potential endocrine Disruptors. Environ Toxicol Chem 19:29232928

Proll G (2005) Biosensorsystem für vollständig automatisierte ultrasensitive Multianalyt-Immunoassays. Dissertation der Fakultät für Chemie und Pharmazie der Eberhard-Karls-Universität Tübingen

Rasmussen TH, Nielsen JB (2002) Critical parameters in the MCF-7 cell proliferation bioassay (E-screen) Biomarkers 7:322-336

Routledge EJ, Sumpter JP (1996) Estrogenic activity of surfactants and some of their degradation products assessed using a recombinant yeast screen. Environ Toxicol Chem 15(3):241-248

Routledge EJ, Sheahan D, Desbrow C, Brighty GC, Waldock M, Sumpter JP (1998) Identification of Estrogenic Chemicals in STW Effluent. 2. In Vivo Responses in Trout and Roach. Environ Sci Technol 32:1559-1565

RPS BKH (2002) Endocrine Disruptors: Study on gathering Information on 435 substances with insufficient data. Final Report for the European Commission, DG Environment. RPS BKH Consulting Engineers, Delft, (NL) in association with DHI Water and Environment, Horsholm (DK) and Kiwa Water Research, Nieuwegeein, (NL). Project: M0355037 (Ref.: B4-3040/2001/325850/ $\mathrm{MAR} / \mathrm{C} 2)$

Rutishauser BV, Pesonen M, Escher BI, Ackermann GE, Aerni H-R, Suter MJ-F, Eggen RIL (2003) Comparative analysis of estrogenic activity in sewage treatment plant effluents involving three in vitro assays and chemical analysis of steroids. Environ Toxicol Chem 23(4):857-864

Schäfers C, Wenzel A (2000) Der Einfluss von Xenooestrogenen auf den Lebenszyklus von Fischen. In: Fraunhofer Institut für Umweltchemie und Ökotoxikologie (Hrsg) Jahresbericht 2000

Schäfers C (2007) Wirkung endokriner Disruptoren in Fischtests: wissenschaftlicher Kenntnisstand. Vortrag auf dem Endocrine Disruptor Fish UBA-Workshop am 10./11.12.07, Berlin

Schäfers C, Frische T, Stolzenberg HC, Weyers A, Zok S, Knacker T (2008) Zur Entwicklung einer Prüfstrategie auf sexual-endokrine Wirksamkeit einer chemischen Substanz bei Fischen. Umweltwiss Schadst Forsch 20:229-233, DOI 10.1007/s12302-008-0014-4

Schirling M, Jungmann D, Ladewig V, Ludwichowski KU, Nagel R, Köhler H-R, Triebskorn R (2006) Bisphenol A in Artificial Indoor Streams: II. Stress Response and Gonad Histology in Gammarus fossarum (Amphipoda). Ecotoxicol 15:143-156

Schmitt C, Oetken M, Dittberner O, Wagner M, Oehlmann J (2008) Endocrine modulation and toxic effects of two commonly used UV screens on the aquatic invertebrates Potamopyrgus antipodarum and Lumbriculus variegatus. Environ Pollut 152(2):322-329

Schreer A (2005) Application of rainbowtrout hepatocyte cultures to study gene expression due to estrogenic compounds. PhD Dissertation des Centre of Environmental Research (UFZ) LeipzigHalle. ISSN 1860-0387 
Schulte-Oehlmann U, Duft M, Tillmann M, Markert B, Oehlmann J, Stachel B, Reincke H (2001) Biologisches Effektmonitoring an Sedimenten der Elbe mit Potamopyrgus antipodarum und Hinia (Nassahus) reticulta (Gastropoda: Prosobranchia). Arbeitsgemeinschaft für die Reinhaltung der Elbe

Schultis T, Metzger JW (2004) Determination of estrogenic activity by LYES-assay (yeast estrogen screen-assay assisted by enzymatic digestion with lyticase). Chemosphere 57:1649-1655

Schwätter F, Hannich CB, Nöthe T, Oehlmann J, Fahlenkamp H (2007) Risk assessment for organic trace compounds in wastewater: comparison of conventional and advanced treatment. Water Sci Technol 56(5):9-13, DOI:10.2166/wst.2007.551

SEC(2007)1635, Commission Of The European Communities (2007) Commission Staff Working Document on the implementation of the "Community Strategy for Endocrine Disruptors" a range of substances suspected of interfering with the hormone systems of humans and wildlife (COM (1999) 706), (COM (2001) 262) and (SEC(2004)1372). Brussels 30. 11.2007, SEC(2007)1635. http:// ec.europa.eu/environment/endocrine/documents/sec_2007_ 1635 en.htm

Segner H, Caroll K, Fenske M, Janssen CR, Maack G, Pascoe D, Schäfers C, Vandenbergh GF, Wenzel A (2003) Identification of endocrine-disrupting effects in aquatic vertebrates and invertebrates: report from the European IDEA project. Ecotoxicol Environ Saf $54: 302-314$

Segner H (2009) Bestimmung von EDC in situ: Vor- und Nachteile. Abstract zum Workshop Nachweismöglichkeiten von hormonaktiven Substanzen in aquatischen Systemen am 11.+12. Juni am Oekotoxzentrum in Dübendorf in der Schweiz

Seifert M (1999) Bestimmung von Oestrogenen und Xenooestrogenen mit einem Rezeptorassay. Dissertation zur Erlangung des Grades eines Doktors der Naturwissenschaften an der Technischen Universität München

Seifert M, Haindl S, Hock B (1999) Development of an enzyme linked receptor aassay (ELRA) for estrogens and xenoestrogens. Anal Chim Acta 386:191-199

Sonnenschein C, Soto AM (1998) An updated review of environmental estrogens and androgen mimics and antagonists. J Steroid Biochem Molec Biol 65(1-6):143-150

Soto AM, Sonnenschein C, Chung KL, Fernandez MF, Olea N, OleaSerrano MF (1995) The E-Screen Assay as a Tool to Identify Estrogens: An Update on Estrogenic Environmental Pollutants. Environ Health Perspect Suppl 103:113-122

Spengler P, Körner W, Metzger JW (2001) Substances with estrogenic activity in effluents of sewage treatment plants in southwestern Germany. 1. Chemical Analysis. Environ Toxicol Chem 20:2133-2141

Sumpter JP, Jobling S (1995) Vitellogenesis as a biomarker for estrogenic contamination of the aquatic environment. Environ Health Perspect 103:173-178

Takeyoshi M (2006) Draft Report of Pre-validation and Inter-laboratory Validation for stably transfected Transcriptional Activation (TA) Assay to Detect Estrogenic Activity.The Human Estrogen Receptor Alpha Mediated Reporter Gene Assay Using hER-HeLa-9903 Cell Line OECD document der EDTA
Thomas KV, Hurst MR, Matthiessen P, McHugh M, Smith A, Waldock MJ (2002) An assessment of in vitro androgenic activity and the identification of environmental androgens in united kingdoms estuaries. Environ Toxicol Chem 21:1456-1461

Tyler CR, Aerle R v, Thutchinson TH, Maddix S, Trip H (1999) An in vivo testing system for endocrine disruptors in fish early life stages using induction of vitellogenin. Environ Toxicol Chem 18(2):337-347, DOI: $10.1897 / 1551-5028$

UBA-Texte 65/95 (1995) Umweltchemikalien mit endokriner Wirkung. Fachtagung in Berlin. UBA-Texte 65/95 ISSN 0722$186 \mathrm{X}$

US-EPA (2008) Status on EPA's Endocrine Disruptor Screening Program (August 28, 2008), http://www.epa.gov/endo/pubs/regaspects/082808_qas.htm

US-EPA (2009) Endocrine Disruptor Screening Program; Policies and Procedures for Initial Screening. RIN 2070-AD 61. http://www. epa.gov/endo/pubs/revised_pandp_frn_041509.pdf

van den Belt K, Berckmans P, Vangenechten C, Verheyen R, Witters H (2004) Comparative study on the in vitro/in vivo estrogenic potencies of 17-b-estradiol, estrone, 17-alpha-ethinylestradiol, and nonylphenol. Aquat Toxicol 66:183-195

van der Linden SC, Heringa MB, Man H-Y, Sonneveld E, Puijker LM, Brouwer A, van der Burg B (2008) Detection of Multiple Hormonal Activities in Wastewater Effluents and Surface Water, Using a Panel of Steroid Receptor Calux Bioassays. Environ Sci Technol 42:5814-5820

Vedani A, Spreafico M, Peristera O, Dobler M, Smiesko M (2008) VirtualToxLab-in silico Prediction of the Endocrine-Disrupting Potential of Drugs and Chemicals. Chimia 62:322-328 Schweizerische chemische Gesellschaft. ISSN 0009-4293

Vermeirssen ELM, Suter MJ-F, Burkhardt-Holm P (2006) Estrogenicity Patterns in the Swiss Midland River Lützelmurg in Relation to treated domestic sewage effluent discharges and hydrology. Environ Toxicol Chem 25(9):2413-2422

Vermeirssen ELM, Eggen RIL, Escher BI, Suter MJ-F (2008) Estrogens in Swiss Rivers and Effluents - Sampling Matters. Chimia 62:389-394. ISSN0009-4293

Watts MM, Pascoe D, Carroll K (2002) Population responses of the freshwater amphipod Gammarus pulex (L.) to an environmental estrogen, 17 $\alpha$-ethinylestradiol. Environ Toxicol Chemi 21:445-450

Weisbrod CJ, Kunz PY, Zenker AK, Fent K (2007) Effects of the UV filter benzophenone- 2 on fecundity and reproduction in fish. Toxicol Appl Pharmacol 225:255-266

Wilson V, Bobseine K, Earl Gray L (2004) Development and Characterization of a Cell Line That Stably Expresses an EstrogenResponsive Luciferase reporter for the Detection of Estrogen Receptor Agonist and Antagonists. Toxicol Sci 81:69-77

Xie L, Sapozhnikova Y, Bawardi O, Schlenk D (2004) Evaluation of Wetland and Tertiary Wastewater Treatments for Estogenicity Using In vivound In vitro Assays. Arch Environ Contam Toxicol 48:81-86

Zacharewski T (1997) In vitro bioassays for assessing estrogenic substances. Environ Sci Technol 31:613-623 